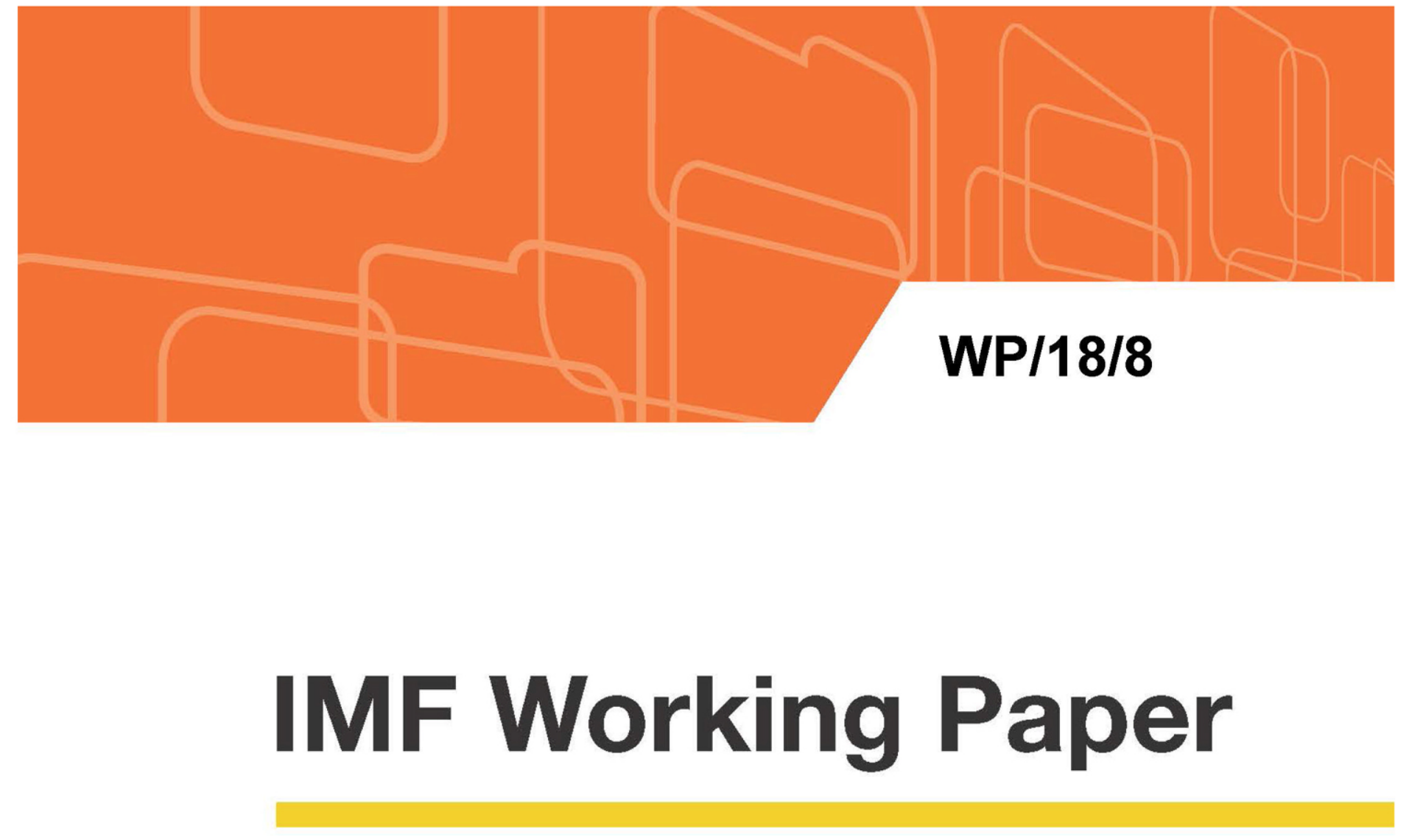

\title{
Regulatory Cycles: Revisiting the Political Economy of
} Financial Crises

by Jihad Dagher

IMF Working Papers describe research in progress by the author(s) and are published to elicit comments and to encourage debate. The views expressed in IMF Working Papers are those of the author(s) and do not necessarily represent the views of the IMF, its Executive Board, or IMF management.

$$
\text { I N T E R N A T I O N A L M O N E T A R Y F U N D }
$$




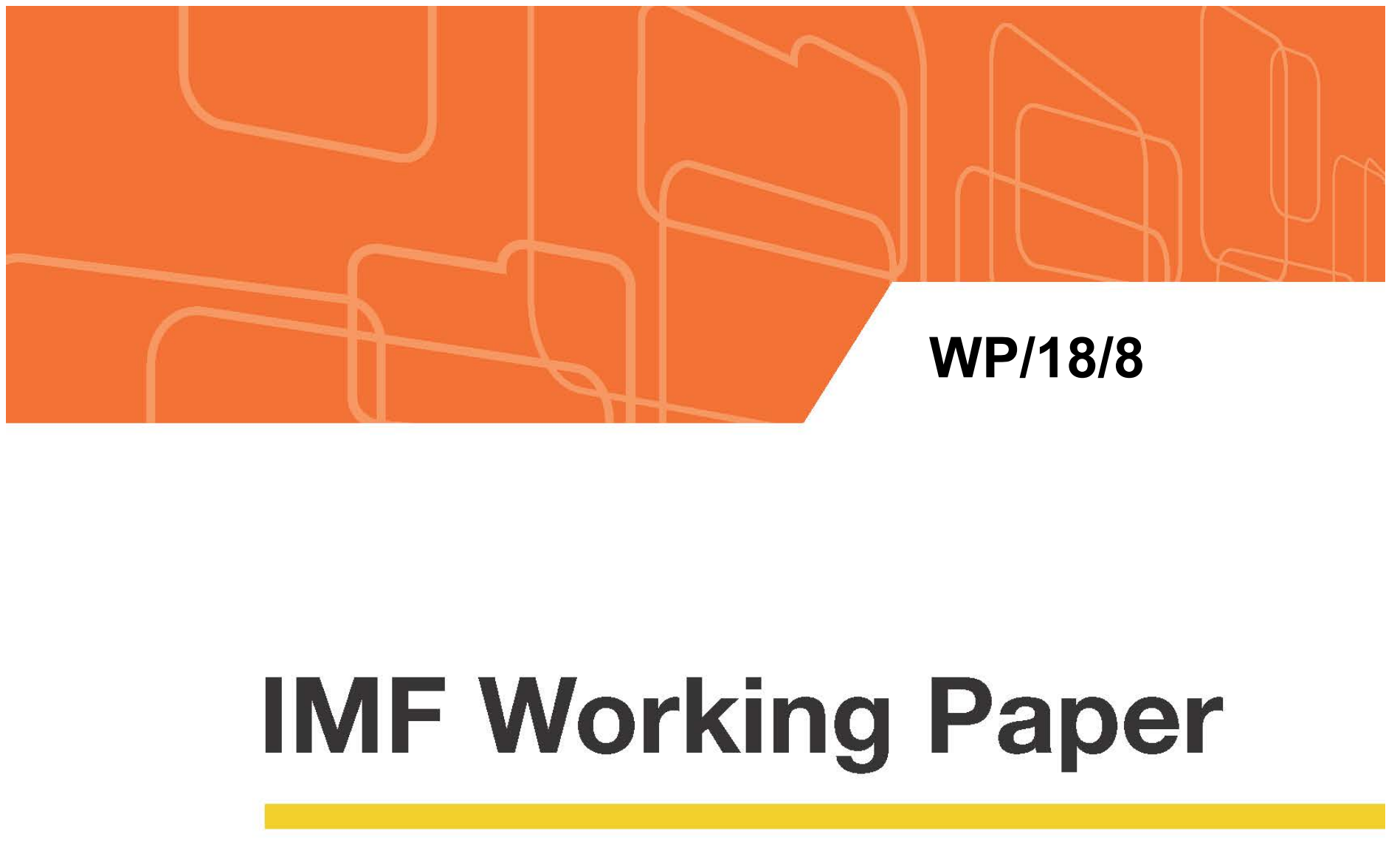

\title{
Regulatory Cycles: Revisiting the Political Economy of
} Financial Crises

\author{
by Jihad Dagher
}

IMF Working Papers describe research in progress by the author(s) and are published to elicit comments and to encourage debate. The views expressed in IMF Working Papers are those of the author(s) and do not necessarily represent the views of the IMF, its Executive Board, or IMF management.

$$
\text { I N T E R N A T | O N A L M O N E T A R Y F U N D }
$$


Research Department

\title{
Regulatory Cycles: Revisiting the Political Economy of Financial Crises
}

\author{
Prepared by Jihad Dagher ${ }^{1}$
}

Authorized for distribution by Maria Soledad Martinez Peria

January 2018

\section{IMF Working Papers describe research in progress by the author(s) and are published to elicit comments and to encourage debate. The views expressed in IMF Working Papers are those of the author(s) and do not necessarily represent the views of the IMF, its Executive Board, or IMF management.}

\begin{abstract}
Financial crises are traditionally analyzed as purely economic phenomena. The political economy of financial booms and busts remains both under-emphasized and limited to isolated episodes. This paper examines the political economy of financial policy during ten of the most infamous financial booms and busts since the 18th century, and presents consistent evidence of pro-cyclical regulatory policies by governments. Financial booms, and risk-taking during these episodes, were often amplified by political regulatory stimuli, credit subsidies, and an increasing light-touch approach to financial supervision. The regulatory backlash that ensues from financial crises can only be understood in the context of the deep political ramifications of these crises. Post-crisis regulations do not always survive the following boom. The interplay between politics and financial policy over these cycles deserves further attention. History suggests that politics can be the undoing of macro-prudential regulations.
\end{abstract}

JEL Classification Numbers: D72, D78, G1, G18, N00, P16

Keywords: Financial Regulation, Financial Crises, Boom-Bust Cycles, Political Economy Author's E-Mail Address: JDagher@imf.org

\footnotetext{
${ }^{1}$ This paper has greatly benefited from conversations with, and comments from, George Akerlof, Olivier Blanchard, Charles Calomiris, Stijn Claessens, Giovanni Dell' Ariccia, Avinash Dixit, Peter Englund, Luc Laeven, James Barth, Sole Martinez Peria, Maurice Obstfeld, Carlo Prato, Lev Ratnovski, Assaf Razin, and Lars Svensson. The paper has benefited from excellent research assistance from Abhik Banerji, and Yangfan Sun. The views expressed herein are those of the author and should not be attributed to the IMF, its Executive Board, or its management.
} 


\section{Introduction}

The economic role of the state has managed to hold the attention of scholars for over two centuries without arousing their curiosity. George Stigler, 1964

The year 1720 marked one of the earliest well documented stock market crashes. It took place in England following the South Sea Bubble, which originated from a government sponsored entity, the South Sea Company, but eventually the frenzy spread to a wide array of joint-stock companies. This episode led to the passage and enforcement of the "Bubble Act," a severely restrictive legislation prohibiting the formation of joint-stock companies without explicit approval by the Parliament. This Act, which lasted for around a century, deeply affected economic and financial development in England. It was eventually repealed under intense lobbying at the height of the next bubble in 1825, an episode that also witnessed government sponsorship of booming, including questionable as well as some fraudulent ventures. In turn, the financial crisis of 1825 led to a series of far-reaching reforms and regulations that transformed the financial market in England. While the world has since seen tremendous progress in political and economic organization, even the most recent episodes of financial boom and bust bear resemblance to the earliest documented crises.

Following the Global Financial Crisis, financial regulation has taken a front seat in the policy and academic debates. Policy makers around the world have sought to make finance safer by overhauling the regulatory landscape (see, e.g., Claessens and Kodres, 2014).

However, preventing the next crisis involves more than just an understanding of how the existing regulations failed, but also why they failed.

Clearly, understanding how and where did regulations fail is of utmost importance to address existing vulnerabilities. In the case of the U.S. financial crisis of 2008-09, there is ample evidence of regulatory and supervisory weaknesses, increased complexity of financial instruments, and inadequate (and in some cases negligent) risk management by financial companies. These factors which created an environment for a perfect storm have duly received close examination by the literature (see, e.g., Shiller, 2008, Gorton, 2010, Acharya et al, 2010, Claessens et al, 2010, Dewatripont, 2010, Acharya et al, 2011, Financial Crisis Inquiry Commission, 2011, Levine, 2011, Blinder, 2013). The macroeconomic context that set the stage for the Global Financial Crisis has also been discussed by scholars in the field (see, e.g., Obstfeld and Rogoff, 2009, Blanchard et al., 2010, Stiglitz, 2011).

Virtually all scholarship and opinions about the Global Financial Crisis agree that financial regulation failed at many levels. But the question of why do regulatory failures happen, and whether political economy factors can help explain the poor track record of financial regulators, remains understudied. To be sure, some of the aforementioned research as well

CInternational Monetary Fund. Not for Redistribution 
as other research (e.g., Igan et al. 2012, Mian et al., 2013, Fernandez-Villaverde et al., 2013) does point to failures at the political level, including political interference that helped fuel the boom and weaken regulations. However, these studies tend to be focused on isolated episodes. While economists have often looked for commonalities in the macroeconomic environment across crises, such analysis seems to be lacking when it comes to the political economy of financial policies.

This paper revisits some of the most notable financial crises in history, starting from the South Sea Bubble and ending in the recent financial crises in the U.S. and Europe. The paper examines the political and regulatory stance (which in this paper refers to laws as well as enforcement and supervision) during the booms and busts, drawing on a wealth of scholarship on each episode. It shows that episodes of financial boom went hand in hand with a period of significant deregulation. These episodes were generally accompanied, and sometimes triggered, by procyclical policies by governments that actively amplified credit booms, weakened existing financial regulations and supervision, and engaged in regulatory forbearance. While in most cases the incumbent governments championed laissez-faire policies, they nevertheless engaged in subsidization of credit and intensification of symbiotic relations with bankers and large companies.

When spectacular booms came to an end, the ensuing crises led to major reforms and reversal of earlier policies. It is important to appreciate the political ramifications of financial crises as a backdrop to these changes. Almost all crises lead to deep changes to the political landscape, and virtually always lead to a political turnover. The elected party usually runs on a platform that is, at least on the surface, less friendly to bankers, one that promises tightened regulation and heightened oversight. As a result, the financial regulatory system is overhauled, and new agencies in charge of financial policy are created, sending a strong signal that financial policy is turning the corner. During this phase we usually observe a diminishing support for credit growth, at a time when the economy is contracting and credit availability is severely diminished. In some instances, this period of re-regulation was viewed by scholars as a knee-jerk reaction that suffocated finance and created a patchwork of costly regulations. As we will see in this paper, these new regulations do not necessarily survive the next boom.

Among the ten episodes discussed in this paper, the Swedish banking crisis of the 1990s is the one that least fits the stylized facts of regulatory cycles discussed above. One wonders therefore whether a strong level of governance and institutions that are less prone to private interests could help mitigate these ex-post inefficient regulatory cycles.

Compared to fiscal or monetary policy, financial regulation is a more abstruse subject. The body of literature on financial regulation highlights its opacity. Changes in financial 
regulation, including enforcement and supervision, can be driven by public or private interests. ${ }^{1}$ Policies that on the surface aim to either to modernize the financial system or enhance financial stability can prove to be detrimental to both, and can be driven by private interests. However, the opaqueness of regulation is not a reason to ignore the almost consistent pattern of regulatory changes during and following financial booms and crashes. In order to best address those difficulties, the paper relies on a wealth of existing literature on each episode to characterize specific regulatory actions. From the point of view of this paper, a regulatory policy is pro-cyclical when it helps boost the expansion in credit and asset prices during booms and increase credit restrictions during the bust. Similarly, financial supervision is pro-cyclical when oversight is weakened during a boom and strengthened during the bust. This characterization is independent of the efficiency of such regulatory actions and their uncertain effect on overall welfare.

With these caveats in mind, this paper studies a few of history's most infamous financial booms and busts. The paper focuses on episodes characterized by either a private credit or stock market boom. Other types of crises, such as sovereign debt or exchange rate crises, are beyond the scope of this paper which focuses on financial regulation. The paper examines ten financial crises that rank, without doubt, as some of the most spectacular boom-bust episodes. The list is inspired by the seminal work by Kindleberger, one of the most cited body of research on the subject. In the most recent edition of this book, Kindleberger and Aliber (2011) cites the top 10 financial bubbles. ${ }^{2}$ Since in their book some of the financial crises, particularly the most recent ones are lumped together in the top ten, the crises analyzed in this paper will not overlap completely with Kindleberger and Aliber (2011)'s boom. Nine of the crises studied in this paper feature in their list, but three crises in their list, the two earliest crisis and a sovereign debt crises are excluded from my analysis. This is discussed in further detail in Section 2.

The stylized facts presented in the paper are not merely a re-writing of existing history on financial crises. This paper is the first, to the best of my knowledge, that closely examines the pattern of financial regulatory policies, their political economy, and political consequences across different episodes, over time and across countries. As such, it is relevant to both academics and policy-makers. The relevance of this topic to today's economic policy is selfevident. Financial regulation remains a focal point in economic debates around the world. Further, what makes this paper particularly timely is the high likelihood that the U.S. is on the verge of entering a period of deregulation. Five years after the passage of the Dodd-Frank

\footnotetext{
${ }^{1}$ In most episodes, the focus will be on regulations on banks and other credit-issuing institutions, since most the financial booms in the 20th and 21st (covered in this paper) can be qualified as credit booms.

${ }^{2}$ Google Scholar shows more than six thousand citations for the Kindleberger and Aliber (2011).
} 
Act, and in the midst of a significant stock market boom and a solid economic performance, the current Administration has made credible promises to undo some of the main features of the Act and has already taken steps to that effect, both at the extensive and intensive margins, as I will discuss later. It is important to note that the optimal level of regulation is a topic that is far beyond the scope of this paper. The paper does not take a stand on whether the existing regulatory regime is weak or excessive. What is intended is to view the current trend in a broader historical perspective. This paper shows some examples of kneejerk regulatory backlashes, as well as several examples where deregulation can take a life of its own, leading to weakened approach to supervision, and a decay of existing regulations.

Needless to say, there is a long and very rich literature on financial regulation and their political economy as I discuss in detail in Section 2. This literature has made great strides in understanding the forces behind financial regulation and their consequences. This paper is different in that it focuses on changes in governments' financial policy across a range of financial boom-bust episodes. While related to an extent, the topic of the paper is very different from the literature on financial liberalization, and not just for the fact that seven out of the ten episodes studied are virtually never described as liberalization episodes. This is also discussed in section 2 .

Historians tend to take the view that each episode has its specific context and therefore prefer to examine financial events separately. I try to address this concern by drawing on economic historians' account of each episode. Nevertheless, the paper is more in line with an economic tradition that emphasizes the value of studying correlations and similarities across different episodes (e.g., Kindleberger and Aliber, 2001; Reinhart and Rogoff, 2009).

Section 3 examines episodes of financial boom-bust individually and documents the patterns in financial regulation, their political economy. Section 4, summarizes and discusses the main findings, bringing in additional evidence. Since regulation is hard to quantify, there is a paucity of data to explore the topic empirically. Nevertheless Section 4 presents some limited empirical evidence that, to some extent, helps illustrate the cycle and understand the regulatory backlash from financial crises.

Providing a theoretical explanation to the patterns presented in this paper is beyond the scope of this paper, and is therefore left for future research. Nevertheless, Section 4 also attempts to lay out potential mechanisms that can lead to regulatory cycles. 


\section{Literature}

This paper is related to two major strands of scholarly literature. First and foremost, it relates to a large body of literature on financial crises which often takes into account political economy considerations. The paper is also related to another body of literature on the political economy of financial regulations. Due to space constraints, I will only provide a very brief review of these two strands of literature, at the cost of omitting many influential works on these topics.

\subsection{Financial crises and their political economy}

A large body of scholarly work has been devoted to analyzing financial crises which, until this day, continue to elude economists. The body of existing research highlights the multitude of components that come together to produce a financial shock of such a large magnitude. A range of economic theories have been supplemented by psychological, political economy, and demographic factors.

Even a very brief survey of the literature, such as this one, cannot miss Minsky's work on the topic and his financial instability hypothesis which is summarized in Minsky (1992). He argues that financial crises are endemic to capitalist economies due to the fact that success breeds success and thus inflation and debt-deflation are self-perpetuating. The tension between the financial and real sector feature prominently in this hypothesis. According to this view, economies do not always conform to the classic principles laid out by Smith and Walras.

In a similar vein to Minsky, Kindleberger (1978) views financial crises as the culmination of a process where expectations, financed by excessive credit creation, often result in speculative excesses or manias. Kindleberger's classic treaty on financial crisis, which provides a comprehensive history of financial crises that cover four centuries, also emphasizes self-fulfilling expectations and the role of investor sentiment. This view of financial crises has been challenged by a body of literature (see, e.g., Gorton, 1988, Calomiris and Gorton, 1991, and Calomiris and Mason 2003). A recent highly praised book by Reinhart and Rogoff (2009) covers the full spectrum of economic crises: sovereign debt, banking, inflation, and exchange rate crises. The book offers an impressive empirical analysis of financial crises, and emphasizes how crises often exhibit more similarities than differences throughout history, also highlighting how each boom is, at the time, seen as different from the others, until proven otherwise.

This paper is most related to a large body of work that examines financial crises from a political economy perspective (see, among many, Chancellor, 2000, Haggard, 2000, Horowitz

CInternational Monetary Fund. Not for Redistribution 
and Heo, 2001, Allen, 2004, Wolfson and Epstein, 2013, O Keeffe and Terzi, 2015). Much of this literature is focused on specific episodes (e.g., Haggard, 2000) or offers a collection of case studies (e.g., Horowitz and Heo, 2001, Allen, 2004, Wolfson and Epstein, 2013). Most of the work that examines crises from a cross-sectional perspective, with the aim of identifying common patterns or lessons, usually focuses on institutional weaknesses (e.g., Mishkin, 1996) or on the crisis-resolution aspect (e.g., O Keeffe and Terzi, 2015). This paper is also very related to a literature that reviews financial crises with an emphasis on the historical context of each crisis (e.g., Chancellor, 2000).

The tendency of politicians to fuel booms is something that has been discussed in previous studies such as Rajan (2010), Acharya et al (2011), Fama and Litterman (2012), FernandezVillaverde et al (2013), McCarty, Poole, and Rosenthal (2013) among others. Most of this research is specific to one episode with some notable exceptions. For example, FernandezVillaverde et al (2013) studies the recent crises in peripheral Europe with a focus on the abandonment of reforms. Schwartz and Seabrooke (2009) provides a collection of papers on the political economy of housing policies across the world, with an emphasis on their social underpinnings.

This paper is also related to, and has a bearing on, a long standing literature on financial liberalization (FL). The liberalization literature usually focuses on set of discrete policies, related to the removal of government constraints on the financial market, with an emphasis on the removal of constraints on capital inflows and outflows (see, e.g., Bekaert et al, 2005, Tornell and Westermann, 2005, Kose et al., 2006, Kaminsky and Shmuckler, 2008), particularly in emerging markets and developing economies where the openness to foreign markets took place over a relatively short period of time (mostly during the 1980s and 1990s). The FL literature focuses mainly on two questions: whether FL increases the risk of financial crises (e.g., Kaminsky and Reinhart, 1999, Demirguc-Kunt and Detragiache, 1998, Glick and Hutchinson, 2005) and whether FL increases long run average growth (Bekaert et al., 2005, Henry, 2000). ${ }^{3}$ The fact that FL has in several cases been followed by a boom-bust episode, particularly in emerging markets, makes this paper related to the literature. However, there are more differences than commonalities between this paper and the FL literature. Clearly, the first aspect is that this paper focuses on financial boom-busts, and not on liberalization. Only three out of the ten episodes covered in this paper have been characterized as liberalization episodes. Second, this paper examines financial policies in broader terms, aiming to capture the government regulatory stance, including financial supervision and credit market interventions, whether they fit the description of modernization or not, and whether

\footnotetext{
${ }^{3}$ The driving force of financial liberalization, including political economy factors, has also been examined (See, e.g., Abiad and Mody, 2005).
} 
they preceded the boom or took place during the boom or following the bust. Third, the key pattern discussed in this paper is the cyclicality of regulation while the liberalization literature mostly focuses on discrete events. ${ }^{4}$ By doing so, the paper offers two examples of FL episodes where the modernization of financial markets was followed by policies of credit subsidization and general sponsorship of the boom which ran against the economic principles behind FL. In that respect, this paper has a bearing on the literature by highlighting confounding factors in the relation between FL and financial crises. ${ }^{5}$

\subsection{The political economy of financial regulation}

A longstanding literature on the political economy of banking and financial regulation has sought to understand the behind-the-scene factors that shape these regulations. The literature has increasingly adopted an approach that treats regulation as an outcome of a bargaining between self-interested agents, in line with the economic theory of regulation (see, e.g., Stigler, 1971).

A recent book by Calomiris and Haber (2014) offers a fascinating look at the history and political economy of banking regulations across countries. The book discusses how the 'rule of the game' has been an outcome of bargaining between politicians and bankers. Wartime history provides a simple example of this special relation: governments needed banks to fund wars and in return bankers obtained concessions such as monopoly rights. As a result, bankers and politicians are able to extract rents at the cost of a fragile and inefficient banking system. While the nature of government needs and the concessions it is willing to provide changes over time, Calomiris and Haber (2014) argue that this bargaining game is at the heart of many banking regulations across countries and time. This view is supported by a long literature on the topic (See, e.g., Hammond, 1957, Rondo, 1967, White, 1983, Kroszner, 1998, Calomiris, 2010).

An empirical literature has also studied the passage of specific regulations (or deregulations) often reaching conclusions supportive of the private benefits view of financial regulation (see, e.g., Posner, 1997, Kroszner and Strahan, 1999, Benmelech and Moskowitz, 2010, Mian et al, 2010 and 2013, Rajan and Ramcharan, 2011). Nevertheless, the public benefit view cannot be dismissed all together (e.g., Mian et al, 2010 and 2013). One might reasonably argue, however, that it might be more challenging to empirically establish a public benefit view, as one would have to rule out many private interest forces. Furthermore, evidence of

\footnotetext{
${ }^{4}$ The focus on the political underpinnings of the changes in the government's stance over the cycle, and the political and regulatory ramifications of financial crises also makes this paper very distinct from the liberalization literature.

${ }^{5}$ These confounding factors have been touched upon in Caprio and Klingebiel (1996).
} 
an influence by a concentrated interest group does not rule out other forces nor imply that such regulations fail the public interest test. ${ }^{6}$

While the cyclicality of regulation has received much less attention from the economic literature, it has been briefly discussed in some policy papers. Reagan (2009) warns against over-regulation in response to the latest crisis since its apparent costs might lead to another knee-jerk reaction toward deregulation. Blinder (2015) argues instead that over-regulation can be optimal, based on assumptions related to the decay of regulation, and the various hurdles facing regulators. Both Ragan and Blinder discuss this phenomenon in broad strokes without a formal theoretical model. Aizenman (2009) illustrates how a model where probability of the crisis is updated sequentially applying Bayesian inference can generate cyclicality. In a recent an preliminary paper, Almasi, Dagher and Prato (2017), we examine the cyclicality of regulation in a standard political economy model augmented with a financial sector.

\section{Revisiting financial Crises}

This section surveys some of the most infamous financial crises. The list of crises are based on Kindleberger and Aliber (2011)'s top 10 list. However, the coverage does not fully overlap for a couple of reasons. First, Kindleberger and Aliber (henceforth KL), lumps together several financial 'bubbles' of the 2002-2007 period, specifically, those in England, Iceland, Ireland, Spain, and the United States. Since one of the key objectives of this paper is to explore similarities between the most recent episodes and historical ones, this makes a strong case for studying more than just one of these episodes of the 2000s. The focus on the political economy aspect of these boom-bust cycles dictates that each episode should be studied separately. Therefore I chose to focus on Ireland, Spain, and the U.S., which have experienced by far the most impressive boom-bust cycles of this past decade among large and advanced economies. Further, there is much to be learned by analyzing the similarities and differences of contemporaneous episodes in countries with different political environments. This comes at a small cost of ignoring the Tulip Mania of the Dutch republic during 1630s and the Missippi Bubble of 1720s in France which are listed in KL's list. The former being a frenzy, with limited data in a small market that can hardly be characterized as an important

\footnotetext{
${ }^{6}$ There is evidence, for example, that the regulatory backlash from the Great Depression was influenced by small bankers' private interests (e.g., Calomiris, 2010). Nevertheless, the question regarding the extent to which the regulatory backlash from the Great Depression was driven by public or private interests remains a debated topic. One might argue that the mere fact that the U.S. did not experience a financial crisis until the mid 1980s, despite a prolonged period of rapid growth, would suggest that the regulatory backlash from the Great Depression was beneficial to the overall economy, and not just to specific interest groups.
} 
financial event (e.g., Garber, 1990), and the latter being extremely similar in nature to the South Sea Bubble that features in KL's list and is covered in this paper. ${ }^{7}$ Since I also ignore a sovereign debt crisis from their list, I chose to add the financial crisis of the 1820s in England. Why do I chose the 1825 crisis from among many notable crises? There are several reasons that make this an obvious choice. First, KL's list does not include a crisis from the 19th century, a period that experienced many crises, among which the 1825 was most notable for the number of bank failures and was, according to some scholars (e.g., Neal, 1998), a watershed moment in the financial history of England. Second, the paper can benefit from studying not just variations across countries, but also variations over time within a country, preferably two consecutive major crises. The Great Depression and Great Recession fit this criteria, and are included in this paper. Therefore it would be useful to have a comparable example from another country, while keeping the nine other crises featured in KL. This greatly reduces the potential coverage particularly due to lack of well documented crises in the English literature. ${ }^{8}$ Hence the 1825 crisis becomes an obvious choice.

\title{
3.1 The South Sea Bubble
}

\begin{abstract}
I have enquired of some that have come from London, what is the religion there? they tell me it is South Sea stock; what is the Policy of England? the answer is the same [...] nothing but South Sea.
\end{abstract}

Jonathan Swift, 1720 (author of A Modest Proposal)

This episode is one of the earliest well documented financial bubbles. The South Sea Company (SSC) was a British joint-stock company founded in 1711, created as a publicprivate partnership to trade with South America. At the time it was created, Britain was involved in the War of the Spanish Succession and Spain controlled South America. The trading activity of SSC remained limited however, and many historians argue that there was no realistic prospect that trade would have taken place (e.g., Chancellor, 1999). In fact, the company never realized any significant profit from its monopoly. Instead, it was more

\footnotetext{
${ }^{7}$ There is no substantial evidence that the tulip mania had significant economic repercussions. Garber (1990) characterize this episode as "[...] little more than a mid-winter diversion among tavern regulars mimicking more serious traders."

${ }^{8}$ For example, the Japanese crisis of the 1920s is not well documented, and studies of its political economy are almost non-existent in the English language. Nevertheless, based on what we know from the literature Japan went through a regulatory cycle in the late 19th century and early 20th century. The financial crisis in 1927 transformed the financial regulatory system from a form of free banking with minimal capital requirements (Shizume and Tsurumi, 2016) to a heavily regulated industry with higher capital requirements and restrictions on non-banking activities (Shizume, 2012).
} 
involved in handling government debt. The company rose in prominence by increasing the liquidity of government debt (see, e.g., Neal, 1990, Temin and Voth, 2004). Toward 1720, SSC entered in a bidding war with the Bank of England to convert the remaining of the national debt. During this bidding war the SSC paid bribes to politicians from members of the House of Commons on up (Carswell, 1993). By the time the conversion was approved by parliament SSC's stock had more than doubled.

This episode saw a general increase in optimism and in speculation that sent stocks of SSC and other companies soaring. The rise of the SSC coincided with the advent of new jointstock companies which had also flourished in the stock market. These so-called "bubble companies" included many speculative, deceptive, and ludicrous schemes. The literature is abound with examples of such companies, including humorous fable mocking investors' credulity.

The involvement of the political elite is a matter of public record. As Chancellor (1999) argues: "Any interpretation of the bubble of the 1720 which neglects the role of the government is severely limited.' The company offered shares to politicians and eventually most of the political class was invested in the company, from the King to the MPs. Incentives became more aligned, and despite some opposition, the MPs allowed the company to set its own terms for the conversion of annuities into South Sea stock, which led the SSC to inflate its share price.

This bubble episode had its skeptics. As the share price climbed from $£ 120$ in January 1720 , when the scheme was proposed, to around $£ 550$ in early June skeptics grew louder, including members of parliament. ${ }^{9,10}$ As early as February there was a push by some members of the House of Commons to investigate the "bubble companies," which would have included the SSC. Nevertheless, dissident voices were outweighed by those supporters of SSC who were assuaged by continued bribes.

However, at the height of the bubble, even investors and MPs became more skeptic about the stock frenzy (many of which cashed out before stocks took a dive). The SSC feared that the rise of bubble companies, which competed for investors, could hurt the company's share price. Therefore the company pushed for the 'Bubble Act' which required prospecting jointstock companies to obtain approval from Parliament and prevented activities not specified by the companies' charters. It is now well documented that this Act was driven by special

\footnotetext{
${ }^{9}$ Chancellor (1999) gives many examples of criticism and ridicule of speculators by public figures including the brother of the SSC's founder, Jonathen Swift, Isaac Newton, and Archibald Hutcheson.

${ }^{10}$ Hutcheson had warned of impending collapse writing that "[t]he Managers of the South Sea Scheme appear to me to have copied exactly after the French Mississippi in all the steps which have been hitherto taken...Is there not, therefore, reason to fear, that the parallel will happen throughout?" (Hutcheson 1721, p. 65).
} 
interest group (e.g., Harris 1994), specifically SSC and MPs invested or bribed by the company. The passage of the Act in June 1720 was a form of regulatory forbearance that aimed to extend the boom in SSC's shares. This was followed by a prosecution by the Attorney General of three bubble companies. These measures backfired, and led to a panic in the market that hurt the stock prices of all companies including SSC's.

The decline in shares accelerated in August. By September the Sword Blade bank, which acted as the banker of SSC had failed. The collapse of the stock market precipitated public anger directed at company directors and politicians. The Commons opened an investigation and the four MP directors were expelled from the House. A bill confiscated the profits of the SSC company directors, and another bill was proposed "for the better Establishment of public Credit by preventing, for the future, the infamous practise of Stock-Jobbing." This was followed by Sir John Barnard's Act which restricted short sales and the trade in futures and options.

The fact that the Bubble Act, an act that imposed severe restrictions on incorporation, remained in place and continued to be enforced after the fallout from the 1720 bubble is very significant. It is indicative of the hostile environment toward financial markets that emerged following the crisis in 1720. In other words, while the act was originally driven by private interests - MPs connected to the SSC (many of whom were later prosecuted) attempting (and failing) to extend the boom in SSC's shares - its continued enforcement can only be explained as restrictive regulatory backlash from the crisis. The Act remained in place for a century until the next stupendous boom in 1825. Scholars have often argued that the Bubble Act has constrained the expansion of joint-stock companies, limited the availability of capital, and thus slowed what otherwise would have been a more robust industrial revolution prior to 1830 (see, e.g., Temin and Voth, 2013).

The political repercussions of the crash were also significant. The crash led to a public outrage, with mobs crowding into Westminster. The Parliament was recalled and committee was formed to investigate the South Sea Company which later found widespread fraud and corruption. John Aislabie, Chancellor of the Exchequer, and several members of Parliament were expelled in 1721. Those that were found involved in the fraud were prosecuted and in some cases their estates were confiscated. Robert Walpole, who had been opposed to the South Sea Company (Mckay, 1869), was made Chancellor of Exchequer. He divided the National Debt that had been the South Sea Company into three, between the Bank of England, the Treasury and the Sinking Fund (Ross, 1892). Robert Walpole is generally considered to be the first and de facto the longest serving British prime minister. According to Dickson (1967) the trauma from the South Sea Bubble ushered in an era of more efficient public finance. 


\subsection{The Financial Crisis of $\mathbf{1 8 2 5}$}

There was never a period in the history of this country, when all the great interests of the nation were at the same time in so thriving a condition or when a feeling of content and satisfaction was more widely diffused through all the classes of the British people.

King George IV, February 1825

The boom of 1822-1825 was a period of great optimism in Britain, when a wide array of tenuous schemes found their way to the stock and bond markets with great help from the political elite.

Following the Napoleonic wars from 1803 to 1815 wars, the London Stock Exchange emerged as the dominant capital market in the world. The Napoleonic wars also coincided with the collapse of the Spanish empire in Latin America and the rise of independent states with new financing needs. The newly independent states in that region sought financial resources at a time when European financiers were seeking new investment outlets. This led to the development of an active loan market in London. Investors were optimistic about these new bonds despite the fact that these new states were drawn into regional military conflicts and had not proved their ability to service their debts. Soon, a company formation craze took place, and enthusiasm spread. The stock market also saw a rapid increase in the number of South American mining companies quoted on the stock exchange. Optimism in financial markets transformed even sophisticated financiers again into gullible investors who financed increasingly bewildering schemes. But the voice of dissidents was neutralized by promoters and MPs who sat on the board of these companies (see, e.g., Dawson, 1990). Companies commonly employed members of Parliament and peers as decoy directors to gain political favors (Chancellor, 1999). Even the prime minister, Lord Liverpool, was appointed president of a company that sought to revive the silk industry. Scottish adventurer Gregor McGregor arranged to successfully float a $£ 600,000$ loan to Poyais, his fictitious small country on border of present-day Nicaragua, through the offices of a former Lord Mayor of London.

At a time when The Times and other newspapers became increasingly alarmed at the rate of formation of suspicious companies (Harris, 1994), the Bank of England continued to facilitate the speculation by issuing paper money and credit and by discounting bills drawn by other banks (Dawson, 1990).

As London entered this new phase of optimism and speculation, the laws that had been enacted as a result of the South Sea Bubble were still in place. The Bubble Act continued to require parliament approval for prospective joint-stock companies, and left the Bank of Eng- 
land as the sole approved joint-stock bank. The Act was enforced in tandem with restrictions on futures and options based on Sir John Barnards Act of 1734. Whether the Bubble Act was a binding constraint toward the early 19th century remains debated (Patterson and Reiffen, 1990, Harris, 1994) but what we do know is that the rate of formation of new enterprises has led legislators to call for stricter enforcement of the Act. This effort backfired in March 1825 due to reactions by MPs who were invested in many bubble companies (Dawson, 1990). ${ }^{11}$ (We will see later, in other episodes, other examples of interventions by regulators backfiring due to inteventions by politicians.) These efforts eventually led to the Repeal of the Bubble Act in June 1825. Few have examined the repeal as closely as Harris (1997) did. He finds that the repeal was mostly driven by private interests at the time. In fact, the opposition to the repeal came from conservative lawyers, particularly Lord Chancellor Eldon, who were skeptical about the bubble companies. The evidence brought by Harris (1997) put to rest a misinterpretation (albeit uncommon) of the repeal as being a regulatory response to the financial crisis. Between the time the bill was brought to parliament and its passage in June 1825, the market witnessed a gentle slide in Latin American bond prices.Dawson (1990) dates the market nervousness to sometime between mid-June and late July. It was not until end-August that the market became lukewarm about new bond issues. A full blown panic ensued in the fourth quarter of 1825. The cracks in the banking sector did not appear until September of that year (Neal, 1998).

While the advent of a speculative boom in stocks and foreign bonds might call for a tightening of regulations in place as a way to limit the risk associated with such novel and uncertain ventures, the opposite took place through weaker enforcement and deregulation.

The crash in stock and bond prices eventually led to a run on country banks and banks failures. By end of 1826 close to 10 percent of all English banks had failed. The 1825-26 crisis was perhaps the first major global banking crisis and was a watershed in the financial history of England.

The immediate policy response to the 1825-26 crisis was the Banking co-partnership Act (also known as Country Banker's Act). The public opinion pointed blame at the Bank of England for the crisis (see, e.g., Barnes and Newton, 2014, Calomiris and Haber, 2014). Therefore, the drafters of the 1826 Act had aimed to strip the Bank of England of its monopoly and to stabilize the English banking system with the understanding that greater capital is needed to withstand runs (See, e.g., Newton and Cottrell, 1998). The 1826 Act permitted the formation of joint-stock banks. Banks with more than six partners and freelytransferable shares were allowed to be established beyond a 65 miles radius from London. The Act also encouraged the Bank of England to open branches outside London. The

\footnotetext{
${ }^{11}$ Most notably by Peter Moore who was also the director of several joint-stock companies.
} 
geographical restriction on banks was later removed in 1833 when the Bank of England's charter was up for renewal and government had the opportunity to further strip the Bank of its monopoly.

According to the research on the subject, the response to the 1825-26 aimed to make the financial sector more stable (see, e.g., Neal, 1998, Newton and Cottrell, 1998). The literature does not suggest that there were perverse incentives behind the reaction to the crisis. Nevertheless, modern banking was in its infancy and hence England would go through several banking panics in the three decades that followed (1836-37, 1847, and 1857), each of which generated further fine-tuning of banking laws that eventually led to a more stable banking system in the long term. Calomiris and Haber (2014) discuss how following the 1836 panic the bank of England was required to provide liquidity to other banks in time of crises, creating a moral hazard problem. This was later addressed in the late 1850s through changes in the Bank of England's policy.

What ensued from the 1825 crisis was a series of laws, regulations, and reforms that touched all aspects of the financial sector. According to Neal (1998): "The policy changes that affected the monetary regime - the exchange rates, the structure of the banking sector, the role of the Bank of England and the management of the governments debt — while minor in each particular and slow to take effect, were cumulatively effective in laying the basis for Britains dominance in the world financial system until the outbreak of World War I." Neal (1992) also argued that the crisis led to a series of political reforms over time, leading to the Great Reform Act, which increased the Parliamentary representation of large industrial cities at the cost of 'rotten boroughs' and also increased the number of voters by around $15 \% \cdot{ }^{12}$

\subsection{The Great Depression}

Maintaining a high percentage of individual home owners is one of the searching tests that now challenge the people of the United States.

Herbert Hoover, 1925

We in America today are nearer to the final triumph over poverty than ever before in the history of any land. The poor-house is vanishing from among us.

Herbert Hoover, February 1928

\footnotetext{
${ }^{12}$ A Rotten Boroughs is a parliamentary borough or constituency in existence prior to the Reform Act 1832 which had a very small electorate and could be used by a patron to gain unrepresentative influence within the House of Commons.
} 
Much has been written about the Great Depression, in particular about the factors that transformed the stock market crash into one of the most severe economic contraction in recent history (see, e.g., Keynes, 1931, Fisher, 1933, Galbraith, 1954, Friedman and Shwartz, 1963,Kindleberger, 1978, Bernanke, 1983, Romer, 1988 and 1992, Eichengreen, 1992, Calomiris, 1993, Bernanke, 1994, Obstfeld and Taylor, 1997, Cole and Ohanian, 2004, Christiano et al. 2004, Ohanian, 2009).

Our interest is in the financial regulation over this cycle. But before reviewing the related literature, it is useful to take a minute to review the environment in which the boom occurred.

During the 1920s, the U.S. economy has witnessed structural changes, particularly when it comes to industrial operations. These years saw the emergence of a modern system of management (see, e.g., Chandler, 1977, White, 1990) and the growth of large-scale commercial and industrial companies that produced more efficient vertically-integrated enterprises exploiting economies of scale and scope. These changes came with new financial needs by large corporates. This has led to the enactment of new laws to modernize a severely restricted banking sector. However, the policies adopted went beyond a mere modernization. Some of the regulatory and supervisory changes were pro-cyclical in nature, encouraging the boom in the housing and stock markets.

Prior to 1900, national banks were prohibited from underwriting, dealing, or investing in securities (see, e.g., Wilmarth, 2003). They were also prohibited from originating real estate loans. The passage of the Federal Reserve Act of 1913 was a watershed in the U.S.' financial history. It created the Federal Reserve System as the national central bank which regulated banks together with the OCC (which was founded in 1863 and continued to examine and regulate National Banks). The Act also permitted national banks to make loans secured by farm land in small cities and rural areas.

In 1916, Congress passed the Federal Farm Loan Act creating joint stock and federal land banks to expand mortgage availability to farmers in all regions. The Act created the Federal Farm Loan Board to oversee and regulate the activities of these banks. The joint stock banks were private institutions that benefited from tax exempt debt and were subject to a cap on interest rates they could charge. Over time, the share of these banks in total mortgage issuance increased. Joint stock land banks flourished in the early 1920s at the height of the agricultural prosperity (see, e.g., Alston et al, 1994). The subsidization of mortgage loans to farmers during a time of increased risk was likely politically motivated. Many argue that the reason why many farmers were unable to obtain mortgage loans was simply due to the fact that they were considered too risky (See, e.g., Horton et al, 1942). The relevance of this intervention by Congress is not to be underestimated. A sharp increase in farm foreclosure rates and regional bank failures toward the end of the 1920s is one of the 
hallmarks of the Great Depression.

Soon the mortgage boom spilled over to urban areas, despite the rise in foreclosures rural areas. The inflation-adjusted volume of residential debt tripled between 1921 and 1929 (Snowden, 2010). ${ }^{13}$

The boom also benefited from several changes to the financial landscape. In 1916, Congress authorized all national banks to make loans secured by any type of real estate with terms up to one year (Wilmarth, 2004). The maturity was later expanded up to five years under the McFadden Act of 1927. The deterioration in lending standards by banks is well documented (see, e.g., White, 2009) as their share of fully amortized mortgages decline while 'balloon' mortgages with short duration (3 to 5 years) increased. Households took on these loans as they felt confident about refinancing opportunities. But in addition to the significant expansion of life insurance companies, mutual savings banks, and commercial banks in the non-farm real estate sector it was Building \& Loan institutions (BLs) that perhaps contributed most to the innovations in the sector. State laws made it much easier to incorporate BLs in comparison to banks (Snowden, 1997), and thus the industry grew from 8 thousand to nearly 13 thousand BLs during the 1920s. Some of these new institutions were in fact created by developers and builders to finance their projects. They were the leaders when it came to originating low-downpayment long maturity loans. Despite these worrisome developments regulators did not act. White (1983) discusses how in fact state laws had a tendency to weaken over that period. White (2009) examines changes in OCC requirements and supervision and found that there was also a weakening of regulation of national banks.

The boom got boomier in Florida where corruption and crony capitalism were more extensive, as documented by Vickers (1994) and White (2009). For example, while bank entry in the Florida market was weak between 1907 and 1921 due to OCC restrictions, two bankdevelopers used their political influence with a Florida senator to intervene with the OCC and by 1925 they created 61 national and state banks (White, 2009). OCC examiners who identified weak banks were blocked from closing these banks. Vickers (1994) recounts the story of regulators who granted promoters bank charters and accepted unsecured loans from them, and shows how bank secrecy allowed government officials to deceive the public. Overall, while the literature on banking supervision in 1920s is relatively thin, available research point to a regulatory stimulus to mortgage lending, deterioration in lending standards, a decay of supervision, and an increase in corruption.

The McFadden Act of 1927 was an important piece of legislation, a hotly contested one at the time (see Rajan and Ramcharan, 2011) that increased regional competition in the

\footnotetext{
${ }^{13}$ In 1920 non-institutional lenders held $40 \%$ of residential debt and non-farm home-ownership was also at around $40 \%$. ADD STATS and summarized References.
} 
banking sector. The Act provided that in states where state branching was allowed, national and state bank members of the Federal Reserve System would be allowed to operate branches within the city limits of the parent bank. The Act received a push-back from interest groups driven by landed elites and bankers in areas of high banking rents. Overall, the passage of the Act resulted in more competition at a time when credit was rapidly increasing. The McFadden Act also revised a wide range of banking laws. Most of these revisions went into the direction of enabling national banks to expand their lending, establish subsidiaries, reduce capital requirements for banks operating in certain localities, facilitate consolidations and sanction the practice of trading with bonds (FRB, 1932). In summary, the Act allowed Fed members to transition to a more complex corporation with multiple legal layers operating from multiple locations. While few would contest the merits of this deregulation, particularly when it comes to the extension of branching rights to national banks, the time of the passage fits the pro-cyclical patterns described in this paper.

The structural changes, particularly the industrial and managerial innovations, came with new financial needs by large corporates that could not be met with bank loans alone due to the restrictions on long term bank loans. These needs have contributed to the rise of the securities market. While by law, banks were prohibited from trading in securities (including under the McFadden Act), they circumvented this restriction by creating securities affiliates which grew from 10 in 1922 to 114 in 1931 (White, 1986, 1990). ${ }^{14}$ Despite some early calls regarding the illegality of securities affiliates and concerns about the risks they entail, federal authorities did not take steps to restrict these activities until the Great Depression (see, e.g., Willis et al., 1934, and Peach, 1941).

The regulatory response to the crisis is well known and has shaped the US financial system for decades. The Roosevelt administration enforced a series of radical reforms under the New Deal legislation. First, was the Securities Act of 1933, which contained various provisions to improve information quality concerning securities offered and traded on the market. The Banking Act of 1933 followed. The Act created the Federal Open Market Committee (FOMC), imposed regulation-Q on banks, as well as additional provisions to regulate the relationship between commercial banks and securities firms to limit commercial banks from engaging in speculative activities. The Banking Act of 1933 is sometimes referred to as Glass-Steagall Act although its modern usage usually refers to provisions related to investment banking. The Regulation-Q provision was aimed at discouraging commercial banks from engaging in risky investments by capping the interest rate banks can pay on

\footnotetext{
${ }^{14}$ The National Banking Act of 1864 national banks were directed to invest their funds in short-term self-liquidating loans. However, there was a loophole in the law that permitted banks to perform such "incidental" activities as were necessary to their operations. Banks patently and increasingly took advantage of this loophole during the boom, but regulators did not act.
} 
a variety of deposits and discontinuing the practice of paying interest on demand deposits. The Act also established the Federal Deposit Insurance Corporation (FDIC), offering deposit insurance (originally a temporary measure that was made permanent in 1935) for banks. The Securities and Exchange Commission (SEC) was formed under the Securities Exchange Act of 1934. The Federal Reserve System was reformed in 1935, gaining further independence from the executive branch. Some of the powers formerly held by the Reserve Banks were shifted to the Board of Governors. Finally, Investment Companies Act was implemented in 1940 to formalize the rules governing investment companies.

The political consequences of the Great Depression were very significant. The Republican Party had been the dominant party for most of the 70 years prior to the Great Depression. A political turnover happened in the elections of 1932, which saw a strong comeback of the Democratic Party. Franklin Roosevelt won a massive 57 percent of the popular vote, winning 42 out of the 48 states. The Democrats also won a landslide majority in both houses of Parliament, sweeping 313 out of 435 seats in the House of Representatives. The Democrats retained the presidency for 22 years following the Great Depression. It is widely perceived in the literature that the 1932 election outcome was due to public disgruntlement with the Hoover government (see, e.g., Achens and Bartels, 2005, Lindvall, 2011) and a change in perception about the role of government (See, e.g. Key, 1947, Higgs, 1989, Bernstein, 1989). The latter is key to understanding the dominance of the democratic party in congressional elections in the post-Depression era (See, e.g., Key, 1958, Hershey, 2005, Achen and Bartels, 2005). Needless to say, the Great Depression in Europe also had major political ramifications leading to an ouster of incumbent parties in the post-crisis elections, irrespective of their economic ideology, and intense political polarization (See, e.g., Achen and Bartels, 2005, Cassis, 2014).

\subsection{The Japanese Financial Crisis of the 1990s}

During the second half of the 1980s, Japan experienced an unprecedented boom in stock and land prices. Between 1985 and 1990, the Nikkei stock index surged by more than 200 percent and land prices by around 220 percent. The boom ended in a massive crash in the early 1990s and left Japan debt-ridden and its banks in severe financial distress. While

this episode carries the hallmarks of a typical financial boom-bust, it stands out in the extraordinary inefficiency of the crisis resolution process.

Much of the literature on the Japanese crisis focuses on the macroeconomic factors (external and internal imbalances as well as monetary policy) and the unusual forbearance that defined this episode (See, e.g., Schaede, 1996, Hutchinson and McDill, 1999, Kindelberger 
and Aliber, 2001, Hoshi and Kashyap, 2000, 2004, Mikitani and Posen, 2000, Iwamoto, 2006). This section paints in broad strokes the regulatory policy during that era. It argues that the Japanese financial reform which started in the early 1980s suffered from both sins of omission and commission, using Haggard's (2000) terminology. The rise in the risk profile of bank portfolios during the 1980s happened in tandem with both a deregulation wave and an intensification of bank-politician connections. Political interferences spurred the massive production of the soon-to-be nonperforming loans. The forbearance that followed cannot be explained without an understanding of the political repercussions of the initial crash. The reform of the financial sector did not take place in earnest until following the banking crisis of 1997. The reform aimed to fully liberalize its financial sector but it also firmly addressed institutional weaknesses and the lack of supervisory oversight.

Prior to the 1920s, the Japanese banking system was characterized by free banking. Entry regulations were relatively lax and capital regulation, under the Bank Act of 1890, were minimal (see, e.g., Okazaki and Swada, 2006, Mitchener and Ohnuki, 2009). But following a series of financial crises the government's attitude toward banking shifted toward more regulation and higher entry barriers (Hoshi and Kashyap, 1999).

The tighter regulatory stance that ensued from these crises in the early 20th century remained in place well until the 1970s. During that period, the financial system was highly regulated, underdeveloped, and largely isolated from the rest of the world. Financial institutions, including banks, were rigidly compartmentalized to specific financial products (Frankel and Morgan, 1992, Hotta, 1992). Capital markets were heavily regulated which made corporations, including the largest firms, rely mainly on bank loans to finance their investments. The various interest rates were subject to controls set by the monetary authorities. The banking sector was governed by what is referred to as a "convoy system," which referred to regulatory standard setting that protects the weakest member of the sector. It also manifested itself in an implicit policy of "no entry, no failure, no exits" (see, e.g., Patrick, 1998). Failed banks would be absorbed by other banks. The stability of the financial system allowed the government to routinely employ the system as an instrument to pursue its economic policies (see, e.g., Browne and Kim, 2000).

A series of financial deregulation took place toward the 1980s. The increased deficits following the oil shocks prompted the government to relax regulations on capital markets to broaden the market for treasuries and bonds. The expansion of Japanese banks abroad played a role in the revisions to Foreign trade law to allow Japanese firms to access foreign capital. Corporations began to invest their funds at securities firms which offered Gen-Saki, a form of a repurchase agreement. In response, banks lobbied for previously restricted instruments, which allowed the introduction of CDs and Commercial paper. There are several other

CInternational Monetary Fund. Not for Redistribution 
reasons discussed in the literature (see, e.g., Okina et.al, 2001, Ueda, 2000) which relate to global trends, U.S. pressure, political economy factors that contributed to a rapid pace of deregulation within the space of a decade. However the changes to the financial landscape that took place during that period were not part of a well thought structural reform. While the government did announce a plan for structural reforms, they did not take place before the mid 1990s. Instead, regulatory changes during the 1980s were heavily influence by lobbying from various actors in the financial system. In 1981, the Banking Bureau failed in its attempt to impose stricter disclosure rules on banks as part of the 1981 Banking Reform Act (see, e.g., Amyx, 2004). Securities firms also pushed against a radical modernization of the financial system. The reform of the Deposit Insurance Law increased the assistance provided to banks rescuing failed institutions, with little consideration to the moral hazard implications of this policy.

The dismantling of the old regulatory system, which happened without any changes to regulatory oversight, left a void that would be compensated for by an intensification of informal regulation. Networks became more important than ever, as Amyx (2004) discusses in detail in her book. Corporations and banks saw the importance of connections with the Ministry of Finance and politicians. Crony capitalism thrived in that environment and corruption reached new heights (see, e.g. Browne and Kim, 2001) far beyond what the western world has experienced during its financial manias of the twentieth century (Wood, 1992). The nature of the political system in Japan, in which intra-party competition thrives (see, e.g., Rosenbluth and Thies, 2001) was an important factor. Toward the end of the 1980s the MoF saw its ability to regulate severely diminished, even through traditionally used informal agreements (see, e.g., Patrick, 1998, Karaki, 2000) due to political interferences and a reduction in the number of employees starting in the mid-1980s. For example, in 1984 the MoF division responsible for financial institution regulation was dissolved (Amyx, 2004). The lack of resources at the disposal of supervisors meant they can audit banks only once every two to three years.

As for political interferences, a perfect example is the Jusen, a focal point of the Japanse banking crisis. The Jusen companies were established in the early 1970s, principally for the purpose of providing housing loans to individuals. Toward the late 1980s the jusen companies had gone beyond their original mandate and started lending heavily to real estate speculators and developers. ${ }^{15}$ During the same time, the MoF's ability to influence lending by Jusen diminished after the politically powerful agricultural cooperatives increasingly invested in

\footnotetext{
${ }^{15}$ The Jusen were funded by loans from over 300 financial institutions, which is why the Jusen problem implicated the entire financial system. Between 1980 and 1990 their lending almost quadrupled and the share on corporate borrowers grew from a mere 5 percent to nearly 80 percent.
} 
the jusen helping them navigate through the few regulatory barriers in their way (see, e.g., Iwamoto, 2006).

It is safe to say, based on the existing evidence and the literature, that the regulatory stance during the 1980s was more focused on growth rather than financial soundness and that financial supervision was weakened over that period (e.g., Kawai, 2005). Perhaps a good indication of the government's stance is the surprising trend in interest rates set by the Bank of Japan, which at the time served as an agency of the MoF and was subject to political discretion (See, e.g., Horrowitz and Heo, 2001). Between 1985 and 1987, a time of a booming stock and land prices, interest rates were brought down from 5 to 2.5 percent. When the excessive speculation and bubble economy became clearly visible to the MoF and BoJ toward 1989, the rates began to rise again but it was too late. Similarly, the MOF sought to restrict the volume of lending starting in 1990 but it was also too little too late.

The bubble ended in 1990 with the plunge of the Nikkei stock index, which was followed by a collapse of land and real estate prices in 1992. The crisis that ensued led to extraordinary regulatory forbearance that sets it apart from most other financial crisis (with, perhaps, the exception of the $S \& L$ crisis). The delay in and the mismanagement of the resolution of the crisis was the subject of many scholarly pieces written on the Japanese financial crisis (see, e.g., Hall, 1999, Hoshi and Kashyap, 2000, Mikitani and Posen, 2000, Peek and Rosenberg, 2003, Hall, 2004, Grimes, 2008, Liscy and Takinami, 2013). In a nutshell, the government was unwilling to force recognition of asset losses on banks, which allowed them to continue to roll over their non performing loans, a strategy referred to as evergreening.

The fallout of the crisis first came in the form of political reform. This was, no doubt, due to an avalanche of scandals that shocked the Japanese public, uncovering the real extent of cronyism at all levels of government (see, e.g., Browne and Kim, 2000, Amyx, 2004, Iwamoto, 2006). Japanese voters punished the ruling party, the Liberal Democratic Party (LDP), which had been continuously in power since 1955, in both the upper house and lower house elections. In the lead up to the 1993 elections, the House of Representatives was dissolved leading to the rise of rebellious factions within the LDP. In the 1993 election, former LDP member Hosokawa Morihiro led a eight party coalition to a narrow victory (See, e.g. Nester, 1990, Shinoda, 1998, Cohen, 1999), leading the way to major political reforms. As part of these reforms, the existing electoral system was overhauled to introduce singlemember election district, which aimed to address the perverse incentives created by intraparty competition at the district level (see, e.g., Shinoda, 1998, Rosenbluth and Thies, 2001). In addition to the electoral reform, new regulations were placed on political donations, and government funding of political parties (see, e.g., Blechinger, 2000). During that time, the preoccupation of the general public was focused on political reform, creating an environment 
that constrained crisis resolution and promoted forbearance.

The financial system became increasingly unstable toward the mid 1990s. This was first demonstrated by the failure of seven Jusen companies in 1995. As the government rushed to prepare 685 billion to solve the problem, it faced an unexpected political backlash which curtailed its ability to stimulate the economy. As a result, banks were made to bear a large share of the losses. The public opinion's hostility toward bailouts to the financial system, following corruption scandals, limited the government's capacity to respond to the crisis between 1995 and 1997. It was not until the systemic banking crisis of 1997-1998, which exposed the extent of the problems in the banking sector and its potential implications on the real economy, that the government began to take decisive action. ${ }^{16}$

The regulatory backlash from the crisis was significant. There was a realization first that the system in place, including the 'convoy' system operated by the MoF, was outdated and dysfunctional and that there was a need for clearly defined regulatory and supervisory framework (see, e.g., Kawai, 2005). The regulatory response was slow in line with the forbearance policy, the political gridlock, and the protracted crisis. But over time, the regulatory framework was overhauled. Starting in 1991 the committee on financial reform called for an independent financial supervisor. Other agencies, which were overshadowed by the MoF stepped up their efforts in financial supervision. For example, the Fair Trade Commission became engaged, for the first time since it was established in 1947 (see, Wood, 1992), in securities fraud investigations. In the mid 1990s the government announced the "Financial Big Bang" reform which was a plan aimed at thoroughly liberalizing and reforming the financial system by 2001. Despite resistance, the Ministry of Finance (MoF) gave way to a new Financial Services Agency (FSA). The regulation of banks became the task of the FSA, the Deposit Insurance Corporation (DIC), and the Bank of Japan. The bank of Japan gained independence. The legislation introduced a schedule for removal of blanket guarantees given to depositors. The new framework involved an intensification in inspection of the major banking groups and a reorganization of inspection units. Banks had to follow new rules for more realistic valuation of their assets. The Reorganization and Restructuring reform further intensified examination and monitoring. More importantly, the FSA began inspections of government financial agencies and the postal agencies. The program for Financial Revival included a major tightening in the assessment of bank asset quality and the implementation of a stricter definition of regulatory capital.

Improvements over the existing prudential and supervisory framework extended well into

\footnotetext{
${ }^{16}$ In February of 1998, JPY 30 trillion of public funds were made available to the Deposit Insurance Corporation of Japan (DICJ). Public funds of JPY 1.8 trillion were injected in 21 major banks, among which two large banks were nationalized. More funds were injected over the following years as the estimate of NPLs continued to increase (see, e.g., Fujii and Kawai, 2010).
} 
the 2000s as Japan continued its effort to recover from one of the most severe and costly financial crises in history.

\subsection{The Swedish Banking Crisis}

The banking crisis that swept across the Nordic countries in the 1990s is discussed in most treaties on banking crises (e.g., Reinhart and Rogoff, 2009) and it features as one of the top ten crises in KL. In Sweden for example, the aggregate loan losses among the seven major banks was around 12\% of Sweden's GDP, much larger than the banking sector's total equity capital. The Nordic banking crisis stands out from other similar crises in its speedy and efficient crisis resolution process, something that is often referred to in the literature (See, e.g., Drees and Pazarbasioglu, 1998, Englund, 1999, Honkapohja and Koskela, 1999, Englund and Vihriälä, 2003, Ingves and Lind, 2008, Honkapohja, 2009, Jonung et.al, 2009, Steigum, 2009, Vastrup, 2009).

From the perspective of this paper, this episode also stands out from the others, as it does not fully fit the stylized patterns presented in the introduction, particularly when it comes to the government's role in stoking the boom. I will focus on the crisis in Sweden due to the existing rich literature on the topic. To be sure, the crisis in Sweden in the 1990s did come at the heels of a period of deregulation and a move toward liberalization. However, notwithstanding the relatively thin political economy literature on this crisis, it is not evident that the government sponsored risky lending to the degree we have seen in other episodes. There is also little evidence to suggest that the liberalization was accompanied by a deterioration in supervision or that private interests dictated the deregulatory process. ${ }^{17}$ Beside the fact that one of the drivers of deregulation of financial markets was the need of the government to finance its rising deficits, something we have seen in other episodes, the explosion in credit and the ensuing real estate boom were a side effect of liberalization rather than an active government policy. While the crisis did lead to a change in government, the response to the crisis did not lead to an overhaul of the regulatory landscape. The government continued the liberalization process in an environment of tightened oversight over the banking sector and increased independence of the Riksbank. The Swedish case fits well the usual narrative of fragility induced by liberalization discussed in the literature (See, e.g., Caprio and Klingebiel, 1996, Ingves and Lind, 2008, Kaminsky and Reinhart, 2009). This Swedish exceptionalism could indicate the role that strong institutions and low corruption environment could play in guarding against pro-cyclical regulatory policy. Last, but not least, among the ten crises I cover in this paper, one can argue that the Swedish

\footnotetext{
${ }^{17}$ Although there was some increase in political corruption particularly in the housing sector (Andersson, 2002)
} 
boom happened in the most fragile macroeconomic environment, with rising deficits and unsustainable exchange rate policy. In other words, the crash cannot be fully attributed to an unsustainable credit boom.

In what follows, I will review the the regulatory policy and its political context over the boom-bust cycle.

Similar to many economies in the post-recession period, in the 1940s and 50s, Sweden moved towards a more intrusive government regulation of financial markets (See, e.g., Jonung, 2009, Ögren, 2011, Honkapohja, 2012). This period was defined by low interest rates achieved by voluntary agreements between Riksbank and commercial banks, giving Riksbank the power to determine both lending and deposit rates. The regulated low interest rates and lending rates effectively restricted the role of banks and insurance companies as repositories of illiquid bonds, resulting in weak profit margins (Englund and Vihriälä, 2003). Lending was often determined by political agendas of the government. In the post-war period, one of the objectives of the government was to maintain a high level of investment, especially in the residential sector, to counter the housing shortage created by the war. The Social Democrats in particular made this commitment by launching the million-program which aimed at building 100,000 low rent housing units per year over 10 years, financed by the Riksbank (Jonung, 2009). As a result, any rise in interest rates would spill over into cost of housing (See Jonung, 1993, Englund and Vihriälä, 2003, Jonung et.al, 2009, Honkapohja, 2012). Olson $(1982,1989)$ noted that the credit control regime prior to the 1980 s, benefitted lobby groups like the 'housing industrial complex' that shared close political ties with the Social Democrats. They extensively lobbied for low interest rates and other subsidies as support for the housing sector. The wave of deregulation in the 1980s reversed some of these earlier policies, softening the government's interferences in the financial market. With widespread growth of international trade, technological development and liberalization of foreign markets, households and firms became increasingly dissatisfied with the limitations of domestic credit markets (See, e.g., Sveriges Riksbank, 1985, Englund 1999, Englund and Vihriälä, 2003, Honkapohja, 2012). In face of mounting government deficit, deregulation as a policy issue was brought up by the liberal and conservative opposition. ${ }^{18}$ The Finance Minister, under the Social Democratic leadership between 1982 and 1990, was noted as a major influence in the deregulation movement (See, e.g., Jonung, 1990, Gourvish, 2017). Deregulation was implemented in steps, starting in 1970s and intensifying in the 1980s. In 1972, commercial rents were deregulated and by 1978, the ceilings on bank deposit interest

\footnotetext{
${ }^{18}$ Official statement from the Riksbank acknowledged that 'the aim of restricting credit expansion is not attained, whereas permanent usage of regulations has a destructive effect on the structure of the credit markets.'
} 
rates were removed. With new legislation allowing banks to issue Certificates of Deposit (CDs) in January 1980, tax on CD issuance was removed. Subsequently, ceilings on private sector bond interest were removed and certain restrictions on foreign ownership of Swedish shares were lifted in 1980 (See, e.g., Sharpe, 1995, Englund and Vihril, 2003). The period between 1982 and 1985 experienced rapid and widespread deregulation. The first major change was the removal of quantitative ceiling on private bond issues in 1982, which was followed by the abolition of liquidity ratios requirements for banks in 1983 (See, e.g., Englund, 1999, Englund and Vihriälä, 2003). The removal of interest rate ceilings, lending ceilings for banks, and placement requirements for insurance companies followed suit in 1985 .

The financial landscape underwent a major transformation as players constrained by the earlier regulations, specifically banks and mortgage institutions, rapidly expanded their lending. Prior to 1985, interest rate regulation limited the ability of banks to capture the scarcity rents created by the lending ceilings, effectively opening up the opportunity for aggressive lending by finance companies (Englund and Vihriälä, 2003). With the abolition of interest rate and lending ceilings in 1985, banks, mortgage institutions, and finance companies began to compete for market share. Non-banks financed themselves through bonds, a large part of which ended up being held by banks, exposing them to additional credit risk.

The rapid expansion in credit benefited most the residential and commercial real estate sector. The existing subsidies to the housing sector helped in that regard, although there is no significant evidence to suggest that these subsidies intensified during the boom. Within a short time, the volume of credit was expanding at an unprecedented rate.

The stock market index increased by $118 \%$ between 1985 and 1988 . Over the same period, household financial assets grew from $82 \%$ to $102 \%$ of GDP at the back of increased indebtedness by households. ${ }^{19}$ Prices of office buildings in Stockholm quadrupled between 1980 and 1990, while residential prices doubled over the same period, significantly higher than the European average of a 30 percent increase (Ostrup et.al, 2009). According to many scholars, this extraordinary boom was partly the result of riskier investments in a deregulated environment and lax risk analysis by financial institutions (See, e.g., Jaffee, 1994, Hort, 1998, Englund, 1999, Lamont and Stein, 1999). ${ }^{20}$

As I mentioned earlier, macroeconomic fragilities played a key role in Swedish crisis, particularly interest and exchange rates policy. The Krona, which was pegged to a basket of currencies, was devalued aggressively in 1981 and 1982, by $10 \%$ and 16\%, respectively. To avert speculative attacks the government sent a strong signal that no further devaluations

\footnotetext{
${ }^{19}$ According to Andersson and Jonung (2016) household debt to income increased from $100 \%$ to $130 \%$ between 1985 and 1991.

${ }^{20}$ High risk investments led to the formation of 'bubbles'
} 
will take place. However, it became rapidly evident that the expansionary economic policy was not compatible with monetary policy objective of maintaining a fixed exchange rate (See, e.g., Bäckström's Speech, 1997, Ingves's Speech, 2007, Flodén, 2012). As prices and wages soared, the late 1980s experienced a period of high inflation, causing immense currency speculation, as the Riksbank did not revalue the Krona (See, e.g., Jonung et.al, 2008, Jonung, 2009). As the Krona became the subject of speculative attacks, the Riksbank engaged in contractionary monetary policy to defend the peg (Flodén, 2012). The rise in interest rates sparked the end of the boom as assets prices plummeted in the beginning of the 1990s (See, e.g., Englund, 1999, Honkapohja and Koskela, 1999, Englund and Vihriälä, 2003, Honkapohja, 2009, Jonung et.al, 2009, Steigum, 2009, Vastrup, 2009).

After peaking in August of 1989, construction and real estate stock price index fell by 52 percent and the stock market general index dropped by 37 percent over the following year (See e.g., Jaffee, 1994, Englund and Vihriälä, 2003). House prices fell by $30 \%$ from their peak within the next three years.

Credit losses skyrocketed, with loan losses totalling the equivalent of $12 \%$ of annual GDP (See, e.g., Drees and Pazarbasioglu, 1998). Finance companies, which were heavily invested in the real estate sector, went bankrupt. This spilled into further losses by banks which lent to these companies (See, e.g., Englund, 1999, Englund and Vihriälä, 2003).

The Swedish response to the crisis was commonly praised for being swift and resolute, considering it faced an unprecedented systemic shock (See, e.g. Ingves Lind, 1996, Drees and Pazarbasioglu, 1998, Englund and Vihriälä, 2003, Kaminsky and Reinhart, 1999, Stutts and Watts, 2009, Honkapohja, 2012). The unique aspect of the Swedish resolution model was not just its policies, but also the level of political unity between the government and its opposition in the face of the crisis, despite an overturn in the government at the peak of the crisis in 1991 (See, e.g., Englund and Vihriälä, 2003, Ingves and Lind, 2008)

The general model of resolution was a combination of (a) increased deposit insurance and guarantee of bank debt, (b) acquisition of equity in banks, and (c) purchase of impaired assets identifiable in the balance sheets of the bank (Stutts and Watts, 2009). This prevented panic-induced bank runs, lowered the possibility of a credit crunch and kept the entire resolution process transparent. In December 1992, the Swedish Parliament set up a Bank Support Authority independent of the government, the Riksbank and the Financial Supervisory Authority and provided it with open-ended funding.

Once the financial crisis had been put in check, there was a move toward addressing existing macroeconomic weaknesses, reforming institutions, and a continued liberalization of the economy. Fiscal policy became subject to new requirements to enhance the sustainability of public finances. The post-crisis period also saw a strong move toward a more disciplined 
and independent monetary stance focused on maintaining inflation at an explicit target of 2\% (See Bäckström's Speech, 1997). The Riksbank gained complete independence in 1999. The bank guarantee was disbanded in 1996 and replaced by a deposit guarantee, financed entirely by banks (See Bäckström's Speech, 1997). Market liberalization continued, especially in crucial sectors (for e.g., electricity, railways, telecommunications, civil aviation) and the government broke down traditional market structures to emphasize the need for competitive and open markets (See, e.g., Giersig, 2008, OECD, 2010, Flodén, 2012).

The political repercussions of the crisis were significant. In Sweden, the Social Democratic Party (SAP) had dominated the political scene in the post-war era. It was also in power (as a minority government) in the 80s during the boom. However, in the 1991 election which followed the banking crisis, they lost more seats than they had ever done in a post-war election (See, e.g., Åsard, 1989, Sainsbury, 1992) in favor of the Conservatives (referred to as Moderates). However, the Moderates bore the brunt of the crisis as the crisis deepened. To reduce the burden on the budget, the centre-right government curbed to an extent certain facets of the existing welfare system, such as social benefits, unemployment aids and sickness benefits. This was implemented in the form of 'crisis packages' (Giersig, 2008). Such unpopular measures contibuted to a strong come-back of the Social Democratic Party (SAP) in the 1994 election.

\subsection{The Korean Financial Crisis of the 1990s}

There are various interpretations of the 1994-1996 boom and the ensuing crisis in 1997 in South Korea, most of which fit the regulatory cycle pattern. There is general consensus over the factors that have made South Korea more vulnerable to a financial crisis, although scholars place varying emphasis on any given factor. These include the high corporate indebtedness, rapid liberalization, governance weaknesses in the corporate and banking sector, macroeconomic fundamentals, and crony capitalism (see, e.g., Park, 1998, Krugman, 1998, Radelet and Sachs, 2000, Kruger and Yoo, 2002, Kihwan, 2006).

The objective of this paper is much narrower than that of identifying the causes of the crisis. The question is instead whether the regulatory policies implemented by the government were procyclical.

It is well known that the Korean model has achieved impressive success between the 1960s and the mid 1990s, with an average real per capital GDP growth rate of around 7 percent. The starting point for us is the early 1990s that first witnessed a current account deficit, after years of surplus, and a decline in growth rates from around 8-9 percent to just over 5 percent in 1993-94. The governments response to this economic deceleration is key to 
understanding the context of the Korean crisis (see, e.g., Haggard and Mo, 2000, Kihwan, 2006).

A series of reforms were put in place with the objective of sustaining growth. In order to finance the widening current account, the government has encouraged capital inflows also by amending the Foreign Exchange Management Act. The government liberalized short term ahead of long term flows and placed more restrictions and disclosure requirements on longer term funding (Kihwan, 2006). While this issue has not received much attention, some have argued that the policy bias in favor of short-term capital had to do with protecting local banks monopoly on financial intermediation.

What further helped ignite the investment boom between 1994 and 1996 is the implementation of an economic stimulus package (the so-called 100-day plan) shortly after Kim Young Sam took office in 1993. The package included a fiscal, monetary, and regulatory stimulus. The regulatory stance aimed to liberalize the industrial and financial sectors, but some of the deregulations went too far too quick, and others reflected the close ties between the government and the chaebols, such as the reversal of credit and investment controls on the chaebols. This increased the hold of chaebols on non-bank financial intermediaries who originated loans to their parent companies. The government also deregulated the commercial paper market in 1994. These factors resulted in a rapid expansion in investment. While on the surface, much of these deregulations were in line with textbook market liberalization, there was a significant erosion of regulatory standards and outright regulatory capture (Haggard and Mo, 2000). Regulatory forbearance was also at play. For example, the government converted 24 financially weak short-term financing companies into merchant banks. Most of these new banks aggressively pursued new businesses including risky foreign exchange transactions, as a form of "gambling for resurrection." Much of the literature agrees that financial market liberalization was misguided due to the lack of regulatory oversight (Goldstein, 1998; World Bank, 1998) and the moral hazard created by close ties between businesses - particularly banks - and the government. But the boom was not merely a side effect of government policies in the corporate and financial sector. The government also acted directly in the financial markets through the Korean Development Bank (KDB) increasing its credit supply by an average of 20 percent a year between 1994 and 1996. To put this into perspective, the KDB's equipment investment loans outstanding as of end 1994 stood around 45 percent of total outstanding loans by deposit banks. Finally, and as in the case of most other financial booms, the mid 1990s witnessed an increase in influence-peddling in the banking sector, as some large companies lobbied government officials to maintain credit lines (Haggard and Mo, 2000). One example is the Hanbo scandal which involved key officials from the Ministry of Finance. 
How the crisis unfolded is a topic that has been well covered by the literature (see, e.g., Park, 1998, Balino and Ubide, 1999, Kataoka, 1999, Krueger and Yoo,2002, Kihwan, 2006) and is beyond the scope of this paper. How did the government respond to the early signs of the crisis? In November of 1997, it initiated an effort to push a financial reform bill through the national legislature in order to restore confidence. The bill included the creation of a new Financial Supervisory Boards to consolidate existing regulatory agencies. Scholarly work on this episode suggest that the failure of passing such bill has to do with the fact that the ruling party was concerned about the political costs of such reforms (see, e.g., Haggard and Mo, 2000).

On the 21st of November the Korean government reached out to the IMF for a stand-by arrangement. The IMF program was approved on December 3rd. On December 18th of 1997, Kim Dae Jung became South Korea's first president from the opposition party and quickly enacted thirteen financials bills aimed at reforming the financial system were enacted on December 29th. These were very similar in spirit to the bills that the national legislature had refused to act on in November. The objectives of the financial reform were to restructure and recapitalize financial institutions, increase transparency and supervision, to deregulate the capital market and to remove restrictions on MAs, to liberalize the capital account and to improve the independence and the governance of the BOK.

The political ramifications of the crisis is well mentioned in the literature (See, e.g. Haggard, 2000, Haggard and MacIntyre, 2001, Kihwan, 2006, Kim, 2008). The incumbent party during the boom, the Democratic Liberal party, lost popularity shortly after the crisis. Several major scandals (such as the Hanbo scandal) caused massive disruptions in the intraparty dynamics of the Democratic Liberal party leading to its re-invention as the Grand National Party under Lee Hoi Chang (Haggard and MacIntyre, 2001). During the elections of 1997, the reformed incumbent party lost to the newly formed left-leaning NCNP headed by Kim Dae-Jung, a long-term member of the opposition. During his term, Kim Dae-Jung pursued ambitious administrative reforms aimed at increasing transparency in governance and reducing bureaucratic influence on policy decisions, in addition to the financial reforms discussed earlier. Common goals in the various reforms that took place was reducing the influence of Chaebols and increasing transparency within the public sector. Similar to the Japanese response, the Kim administration also proposed changes in the electoral system at the district level (Haggard, 2000). However, this was widely panned by the opposition parties and NCNPs own coalition member, the United Liberal Democrats (ULD), especially due to the looming National Assembly elections of 2000. 


\subsection{The U.S. Dot-Com Episode of the late 1990s}

We are fortunate to be alive at this moment in history. Never before has our nation enjoyed, at once, so much prosperity and social progress with so little internal crisis and so few external threats. [...] And next month, America will achieve the longest period of economic growth in our entire history.

William Clinton, January, 2000. State of the Union address.

The Dot-Com saga, often referred to as a bubble, witnessed one of the most dramatic stock market booms and crashes in the history of the United States. Information Technology (IT) corporations were at the epicenter of this bubble. Most economists date the beginning of the bubble toward the second half of the 1990s (e.g., Delong and Magin, 2006). By the end of 1996 there was already evidence of overvaluation in the stock market, prompting the famous 'irrational exuberance' speech by Alan Greenspan, the Federal Reserve Chairman. But the boom accelerated in the late 1990s. Between September of 1998 and March of 2000, the NASDAQ composite index rose by 170 percent. The crash was equally dramatic and affected the overall stock market with NASDAQ composite and SP 500 indexes falling, within a year from their peak, by around 60 percent and 20 percent, respectively. Both continued their decline during the following year, reaching, within two years of the bust, a trough around 75 percent and 40 percent below the peak. The Dow Jones Internet stock index plummeted by 93 percent from peak to trough.

A stock market crash is a key feature of financial crises (see, e.g., Kindleberger, 1978, Claessens and Kose, 2013). Despite the fact that the banking sector remained unscathed, the sheer size of this financial boom-bust cycle - the economy lost around $\$ 5$ trillion in total wealth from peak to trough - makes this episode a notable period in the history of financial markets, featuring as one of the top 10 financial bubbles in KL.

There is a broad agreement in the literature that the roots of the Dot-Com boom lay in the unprecedented technological innovation that took place during 1990s (see, e.g., Shiller, 2000, Baily, 2002, Ofek and Richardson, 2003, Pastor and Veronesi, 2006, Jermann and Quadrini, 2007, Perez, 2009). The Internet technology became commercially available in the mid-1990s and the years that followed saw a rapid growth in IT investment, which averaged around 24 percent between 1995 and 2000. There was a palpable sense that the world was entering a new economy. But just as is the case with other boom episodes the optimism soon led way to an euphoria that swept the stock market. Thousands of IT and Internet firms were created within a short period during the late 1990s. Between 1998 to early 2000, the Internet sector earned over 1000 percent returns on public equity.

CInternational Monetary Fund. Not for Redistribution 
The Dot-Com episode took place at a time of a rapid deterioration in corporate governance resulting in infamous fraud scandals that emerged following the bust. Legal scholars, particularly legal experts in securities laws (see, e.g., Coffee, 2002, Western, 2004, Gerding, 2006), saw the 1990s as an episode of dramatic deregulation of the securities industry. These deregulations happened through congressional actions, laws, and a weakening of regulatory oversight. In what follows I describe some of the (de facto and de jure) regulatory changes during and following the boom which will go to show the procyclicality of regulation during that episode. Since, unlike most of the other modern crises covered in this paper, the Dot-Com boom, was a boom limited to the stock market (and not in credit and financial intermediation), the main focus will be on securities regulation.

In 1995 and 1998, under pressure from Wall Street congress passed two laws that increased hurdles against private securities litigation. The first was the Private Securities Litigation Reform (PSLR) act of 1995, a hotly debated bill enacted by the Republican majority in congress over a veto by President Bill Clinton. The main argument behind PSLR was that securities litigation has gone out of hand, and therefore there was a need to increase the hurdle against such lawsuits, many of which, proponents argued, were frivolous. Opponents argued that such claim is exaggerated, as demonstrated by the relatively small annual number of consolidated suits (e.g., Seligman, 2004). PSLR led to a migration of lawsuits from federal to state courts. In response, Congress passed the Securities Litigation Uniform Standard (SLUS) act of 1998. SLUS precluded class actions alleging securities fraud from being brought in state courts. Interest groups played an important role in pushing for the passage of these laws and resisting regulatory actions (Coffee, 2002). Roberts et al. (2003) show the extent of influence and lobbying by the American Institute of Public Accountants (AICPA) and the largest six accounting corporations. They spent in the decade leading up to the enactment of PSLR around $\$ 17$ million on campaign contributions alone, with this reform being very high on their agenda.

Many legal scholars (see, e.g., Coffee, 2002, Gerding, 2006) argued that these laws weakened corporate governance. Seligman (2004) also argues that PSLR and SLUS have contributed to the rise in fraud but he also points to other factors, including the stalling growth in the SEC budget during the boom years (1993-2000) in comparison to previous years, just when every measure of securities' activity was growing far faster than before. Some also argued that the Congress and the SEC adopted an approach that helped fuel conflicts of interests within the big accounting companies which were allowed to shift focus from auditing financial statements to offering more lucrative management consulting services. ${ }^{21}$

\footnotetext{
21 ScotJ. Paltrow, SEC Chief Shift on Investor Bill is Linked to Senate Pressure, L.A. Times, Nov. 22 , 1995, and Seligman (2003).
} 
The boom period also witnessed a shift in judicial doctrine that also placed high hurdles on securities lawsuits such as the "bespeak caution" doctrine. ${ }^{22}$ The doctrine against "fraud by hindsight" ("FBH") has also become a hurdle that plaintiffs in securities cases must overcome. ${ }^{23}$

Not to forget the elephant in the room, the Glass-Steagall Act was repealed in 1999. Just as the Bubble Act inherited from the South Sea Bubble was repealed a century later at the height of the 1825 bubble, the Glass-Steagall act had a similar fortune. A post-crisis Act repealed at the height of another extraordinary boom. While it is not clear that the repeal of Glass-Steagall had significant implications to the securities boom that was underway, the timing of its repeal is not to be downplayed.

The fallout from the Dot-Com burst led to a series of legislations and re-regulations that aimed to address the weaknesses that allowed optimism to grow without scrutiny from analysts, auditors, and regulators. The New York State Attorney General revived an eighty year old legislation to investigate research analysts, the NYSE, and financial institutions. The National Association of Securities Dealers (NASD) brought actions under existing rules against specific individuals (Gordon, 2002). SEC investigations increased dramatically, also targeting notable auditing firms. ${ }^{24}$

With no doubt, the most notable regulatory response to the crash was the SarbanesOxley Act (SOX), passed in July 2002. An extensive literature has studied SOX (see, Ribstein, 2002, Coates, 2007) and its economic implications (see, e.g., Kamar et al, 2006, Engel et al, 2007, Zhang, 2007). SOX was mainly designed to address structural problems facing the auditing industry, which was deregulated during the boom. It created the Public Company Accounting Oversight Board (PCAOB), a quasi-public institution that enlisted auditors to oversee and regulate auditing. Previous efforts by regulators to address conflicts of interests during the boom were finally taken seriously under SOX which called for the Securities and Exchange Commission (SEC) to "foster greater public confidence in securities research, and to protect the objectivity and the independence of securities analysts." The Act also addressed the off-balance sheet problem that was particularly important in the case of Enron and provided legal protection for corporate whistle-blowers. At around the same time, the SEC implemented rules that enhance disclosure about critical accounting matters.

\footnotetext{
${ }^{22}$ In Securities law, the bespeaks-caution rule states that if soft information in a prospectus comes along with a cautionary language that warns the investors about the actual results or events which may affect performance, then the soft information may not be substantially misleading to investors. Soft information may consist of forecasts, opinions, estimates, and projections about future performance.

${ }^{23}$ Although some scholars argue (see, e.g., Gulati et al., 2005) that the FBH doctrine was part of an effort to manage a quagmire of disputes and time-consuming procedural motions.

${ }^{24}$ For example, the SEC implicated PricewaterhouseCoopers with over 8000 violations and brought a fraud case against Arthur Andersen, which subsequently went out of business.
} 
The NYSE and the NASDAQ proposed new listing requirements that impacted corporate governance and the composition of board members (Gordon, 2002).

Opinion on SOX remains divided. Some see it as the most important improvement in federal regulation of securities since the New Deal (e.g., Seligman, 2004) while others argue that SOX was more of a political knee-jerk legislation rather than a well-thought regulatory response (e.g., Romano, 2005). To some, the Act went too far and imposed unnecessary costs on corporation (see, e.g., Ribstein, 2002, Solomon and Brian-Low, 2004, FEI, 2005, Romano, 2005). But the question of whether its benefits outweigh the associated costs is

still subject to debate. Interests groups and prominent politicians have called for a repeal of SOX during the mid to late 2000s, but the financial crisis of 2008 meant that there will be little public appetite for deregulation.

The political consequences of the Dot-Com crash were at best muted and most likely non-existent. This is not surprising given that the crash, which affected mostly the unleveraged stock market holdings of upper income households (e.g., Mian and Sufi, 2015), did not result in a banking crisis, nor did it have major repercussions on the overall economy, except for a short lived recession. Further, the crash happened under the new administration of George W. Bush who enacted as a response the Sarbanes-Oxley Act. Last but not least, the crash happened shortly before the events of 9/11, which became a focal point of politics during that period. The monetary easing that followed these events helped support a strong recovery and a booming housing market.

\subsection{The Irish Financial Crisis of 2008}

It seemed more sensible to keep all these guys who were buying stuff in London and Paris in Ireland. I accept that was wrong and that we should have said, 'so be it.'

Berthie Ahern (former Prime Minister) in an interview with the Independent, November 30, 2014

How did a remarkable economic transformation that was the subject of praise and emulation give way to a phenomenally unsustainable financial boom? Was the property bubble a byproduct of the economic transformation or can it be traced, just like in the case of other booms, to excessive government sponsorship?

The Irish experience is an interesting case study due to the sheer magnitude of the financial cycle. It offers an example of how a series of successful pro-growth deregulations can give way, over time, to an over-confidant approach to laissez-faire, so much so that some 
have referred to Dublin as being the "Wild West of European Finance." 25

It is useful to first briefly review some statistics to illustrate the magnitude of the boom. ${ }^{26}$ Between 1996 and 2006, real house prices grew by around 190 percent in Ireland, in comparison to 60 percent in the United States. Prices have peaked around the same time as the U.S., in the first quarter of 2007. In 2013 Q1 the real property prices index was half of its peak value. Income from housing construction grew from 4-5 percent of national income (the OECD average) to 15 percent at the peak of the boom in 2006-07 (Kelly, 2009). Bank lending to households reached twice the national income in 2008, (as compared to 60 percent in 1997 which was below the European average of 80 percent). In 2008, lending to developers alone accounted for 40 percent more than the total lending levels in 2000 (Kelly, 2009). Based on statistics from the World Bank, Ireland attracted five to ten times more FDI (as a percentage of GDP) than countries like Greece, Spain and Italy.

The unfortunate end of the Irish financial boom should not lead one to underestimate the successes of the Irish economy. The Irish economy took off in the late 1980s after a disappointing history in the late 1970s and early 1980s which saw a deep recession and large budget deficits. Several factors came together to create the Irish miracle. The year 1987 was to some extent a watershed moment with the election of a new government, led by Fianna Fail, and the emergence of a new pro-market conservative liberal political party (Progressive Democrats) who enacted a series of pro-market reforms. These included active industrial policies, low corporate taxation, and the establishment of the International Financial Services Center. During that year, Ireland also voted for the Single European Act. These new policies marked a turnaround contributing a rapid growth, averaging around 6 percent between 1988 and 2000. Growth during that period was mainly driven by an increase in hours worked (see, e.g. Villaverde and other) while productivity was growing at a similar rate to other European countries.

The Irish credit and housing boom can be traced to the mid 1990s. There are several important economic factors that contributed to the boom, and these are the usual suspects: a growing population, an increase in household formation, rising real incomes, and an extraordinary flow of cheaper credit from the EU. But one cannot underestimate the role of pro-housing policies and weakened regulations in fueling the housing and financial boom that was about to come.

Ireland has had a long tradition of pro-ownership policies, which helps explain its high ownership rate ( $88 \%$ prior to the boom). Yet, as the housing boom progressed these incen-

\footnotetext{
${ }^{25}$ New york Times reference

${ }^{26}$ For a comprehensive review of the Irish boom-bust I refer the reader to (See, e.g., Alberdi and Levenfield, 1996, Honohan, 2010, Menelaos and Norris, 2011, Connor et.al, 2012, Dellepiane et.al, 2013, FernandezVillaverde et.al, 2013, Norris and Coates, 2014).
} 
tives became even more generous, and subsidies and tax breaks were given for homeowners, developers, and investors (See, e.g., MacLaran and Kelly, 2014, Norris and Redmond, 2005, Dellepiane, et al., 2011, Menelaos and Norris, 2011). For example, stamp duties were reduced at several occasions during the boom, and, according to The Commission of Investigation into the Banking Sector in Ireland (henceforth CIBS, 2011) "arrangements existed whereby stamp duty could be legitimately reduced or avoided entirely." Tax deductions on interest payments are not unique to Ireland, but Ireland went further than most countries by not imposing taxes on capital gains for owner-occupiers on the sale of primary residences. Virtually, no domestic property taxes were imposed. The use of Section 23 relief, under which the cost of building rental accommodation could be set against tax, grew substantially despite it being originally only aimed at neglected urban areas (OToole, 2009).

Large fiscal incentives to home-ownership and to real estate investments were politically driven and were channeled to areas with little social and economic return (see, e.g., Dellepiane, et al., 2011). These and other subsidies (such as the Seaside Resorts Tax Scheme which was estimated to have cost more than 300 million Euros) has helped fuel a boom in construction. CIBS (2011) notes concerns by the Department of Finance regarding tax breaks and high rates of expenditures to meet social and other priorities of the government, but the report suggests that the minister of Finance was under considerable political pressure not to take action. This helps explain why internal reports at the Department of Finance (DoF) suggesting significant risks from the housing sector, and similar warnings from The Economic and Social Research Institute to the DoF, never made it to public statements by the Minister and received virtually no action.

Unlike the boom in the housing sector in the US, the expansion in mortgage credit was a plain vanilla credit expansion that did not rely on sophisticated financial instruments. So how did the the risks escape financial regulators? This can be only understood in the context of the overall changes that have taken place in the approach to and philosophy of financial regulation prior and during the boom. A key turning point was the reform of financial regulation and the establishment of the Irish Financial Services Regulatory Authority (IFSRA) in 2003. The case for reform was strong. With Dublin firmly established as a financial hub, following the creation of the International Financial Services Center in 1987, a succession of scandals related to tax evasion, insurance and client fraud, required a comprehensive response. The commission tasked with investigating these scandals (see McDowell Report, 1999) found substantial weaknesses in the Central Bank's approach to supervision and called for the creation of a new and independent regulator. These calls faced substantial push-back from both the Government and the Central Bank (see, e.g. Westrup, 2005, OSullivan Kinsella, 2011) and the final outcome was a hybrid structure: IFSRA would be a constituent

CInternational Monetary Fund. Not for Redistribution 
part of the Central Bank but given the necessary independence for the successful regulation.

However, political forces led the IFSRA to adopt a principle-based regulation. This consists of the regulator setting out basic principles (in areas such as solvency, governance, and consumer protection) and allowing banks to decide how best to align their corporate objectives with predefined regulatory outcomes without being prescriptive. This approach was consistent with the governments expressed vision at the time of 'light-touch' regulation. Scholars and commentators have made the point that, effectively, light-touch regulation in Ireland meant nearly no regulation (see, e.g., Clarke and Hardiman, 2012). Clarke and Hardiman (2012) argue that: "The reasons why the regulatory failures took the form they did cannot be understood without acknowledging that this approach to regulation was tacitly endorsed by the government [...], government priorities were more attentive to the interests of bankers, the builders, and the property developers [...]." The protection given by the government to the banking sector and light touch approach can be illustrated with some examples among the many documented in various policy papers such as the CIBS (2011). While the financial regulator had the power to to require financial institutions to provide Directors' compliance statements, to simply confirm that the institution complied with its relevant obligations during a specified period (which is then subject to verification by auditors), this power was not exercised. CIBS (2011) suggests that a push back from the industry was influential, and that communications between IFSRA and DoF led this issue to be dropped. IFSRA and DoF were aware of weaknesses and lack of checks and balances at certain banks, particularly the Anglo-Irish bank, corrective action was at best muted (CIBS, 2011, Eichengreen, 2015). Another example of regulatory relief is illustrated by the fact that, during the boom, Ireland was one of the few countries (five out of forty five jurisdictions) that declined to participate in an IMF program to monitor offshore financial centers (IMF, 2006).

In the aftermath of the crisis various policy makers in Ireland have acknowledged the significant role of this light-touch approach in the making of the crisis. In a report addressing the Minister of Finance, the governor of the Central Bank detailed the weaknesses of the regulatory model which assumed that well-governed banks could be relied upon to make safe and sound decisions (see Honohan, 2010). In 2009, the then ex-prime minister Berthie Ahern suggested that the creation of the new regulator was one of the key mistakes that led to the crisis, admitting he had never sought the council of regulators. ${ }^{27}$

Credit standards continued to deteriorate over the boom and banks became more and more invested in the property boom. Loan-to-Value (LTV) ratios continuously increased. More than half of newly originated loans in 2004 had an LTV of 90 percent and above. This

\footnotetext{
${ }^{27}$ http://www.ft.com/intl/cms/s/0/becb8b70-b917-11de-98ee-00144feab49a.htmlaxzz3XxOcxujp
} 
share increased to almost two thirds in 2006, within almost a third of the origination being at 100 percent LTV.

Following the crisis, the Irish financial regulatory system was overhauled. The Central Bank Reform Act 2010 combined the functions of the Financial Services Authority into the Central Bank. This time, however, the Central Bank adopted a more intrusive approach to supervision (IMF, 2014) and a risk-based approach were implemented. This Act was followed by the CBCIR Act of 2011, which established a Special Resolution Unit. The Enforcement Act in 2013, was a significant piece of legistlation that laid the ground for a new framework to enhance the regulation and supervision of financial institutions and the enforcement of financial services legislation. The Act enhanced the Central Bank's authority as a regulator and harmonized the requirements across all financial institutions supervised by the Central Bank.

In the wake of the crisis, voter frustration led to a political turnover of historic proportions, both at the local and national level. Prior to the local elections of 2009, corruption scandals caused disruptions in the intra-party dynamics of Fianna Fail, leading to the resignation of party leader and Taoiseach, Bertie Ahern. In the 2009 elections, the opposition, Fine Gael, became the largest party at the local level (an unprecedented feat for the party), representing a firm rejection of the incumbent partys policies. ${ }^{28}$ In the general elections of 2011, Fianna Fail suffered the worst defeat by an incumbent government in Ireland (Lord, 2011). A coalition of the conservative Fine Gael and smaller left-leaning Labor Party came to power, securing a majority share (68 percent) in parliament (See, e.g., Kriesi, 2012, Hardiman and MacCarthaigh, 2013). The EU-IMF bailout package was also unpopular and several opposition parties performed well on the anti-bailout agenda (See, e.g., Hardiman and MacCarthaigh, 2013, Whelan, 2014). The coalition government elected in 2011 initiated institutional and political reforms driven towards a more efficient form of governance, which involved a centralized bureaucracy and higher accountability in public service (Hardiman and MacCarthaigh, 2013).

\subsection{The U.S. Great Recession of 2007-2009}

We can put light where there's darkness, and hope where there's despondency in this country. And part of it is working together as a nation to encourage folks to own their own home.

George W. Bush, October, 2002.

\footnotetext{
${ }^{28}$ (Kinsella and Kinsella (2009) argue that the government's failure to claim responsibility for the crisis aggravated voters' frustration.
} 
The U.S. financial crisis of 2007-08 is another example of a regulatory cycle. It is the same type of lending that the government sponsored, the very financial instruments that it deregulated, that contributed to creating the perfect storm that later resulted in the regulatory backlash.

While the U.S. financial crisis of 2007-08 crisis was a boon for book publishers, its political economy remain under-emphasized. Recently Lo (2016) has written a review of twenty one books on the crisis, eleven authored by academics and ten by journalists and policy makers. Only three of these books address head-on the political economy of the crisis, mainly focusing on the government sponsorship of mortgage finance (McLean and Nocera, 2010, Acharya et al, 2011, Morgenson and Rosner, 2011).

That is not to say that the political economy of the housing crisis has not been studied. Indeed a string of academic papers has been written on the topic (see, e.g., Acharya, 2011, Congleton, 2009, Chwieroth, 2011, Igan et al., 2011, Mian et al., 2010 and 2012, Wallison, 2010). The wealth of data available to researchers has allowed the identification of the effect of financial regulations on lending and the political economy factors behind these regulations and interventions (see, e.g., Dell'Ariccia et al. 2008 and 2012, Mian et al, 2008 and 2010, Dagher and Fu, 2009 and 2016, Igan et al., 2011). While opinions and findings might be divided on the extent to which the Community Reinvestment Act (CRA) of 1977 has contributed to the crisis, few would deny that other government interventions and sponsorship were significant factors.

The policies we are interested in are those related to the regulation of the housing and financial markets and government interventions during the boom.

Supporting homeownership has long been a bipartisan objective in the United States. ${ }^{29}$ But in the early 1990s, the pro-ownership policies were intensified with the Congress' enactment in 1992 of an affordable housing mandate for two government sponsored agencies (Henceforth GSEs), Fannie Mae and Freddie Mac (e.g., Barth, 2009, Wallison, 2010, Acharya et al, 2011,). Originally these firms were established to purchase loans from originators creating a liquid secondary mortgage market. ${ }^{30}$ The affordable housing mandate stipulated that a share of the the pruchases by the GSEs had to satisfy the affordable housing criteria. This threshold kept increasing over time, especially over the boom period, going from 30 percent in 1992 to $55 \%$ in 2007. In addition, a "special affordable" housing mandate required that a share of the purchases be reserved for low income borrowers. In 2001, the threshold increased from 12 to 20 percent, and continued increasing thereafter, with the objective of meeting a

\footnotetext{
${ }^{29}$ For more comprehensive review see, e.g., Grigsby, 1990, Rypkema, 2002, Grigsby and Bourassa, 2003, Becker et.al, 2008, Andrews and Sanchez, 2011

${ }^{30}$ Fannie Mae was established following the Great Depression in 1938. Freddie Mac was established in 1970.
} 
target of 28 percent in 2008 (Roberts, 2008).

To get an idea of the degree of politicization of the housing market it is sufficient to mention that from 1993 to the 2007 over 700 roll calls in the House alone were related to affordable housing, home-ownership, or subprime according to the congressional Research Service, as reported in Mian et al (2008). Needless to say, while not all of these bills went into the direction of increasing mortgage credit, support for homeownership was on the rise over that period as reflected by the increasing affordable housing mandate on the GSEs. this led the agencies to increase their purchases of subprime mortgage-backed securities. This has contributed to the dramatic increase in the volume of risky lending and securitization practices by the private sector. ${ }^{31}$ Evidence suggest that HUD's decision was influenced by both the industry and Congress (see, e.g., Mian et al, 2010). In 2003, the American Dream Downpayment Act was signed into law, providing $\$ 200$ million annually for downpayment assistance to low-income homebuyers. While this pales in comparison to the overall subsidy to housing, it illustrates the commitment to further support home-ownership at a time when the market was already booming and ownership was on the rise.

Despite pressure from consumer advocacy groups, no major legislation was passed to impose stricter regulations on the subprime lending. In fact, several were proposed and virtually no major legistlation addressed this issue prior to the crisis. ${ }^{32}$ It is also well documented in the legal literature that this period saw an increased de jure and de facto preemption of state anti-predatory lending laws by bank regulators. The Office of Thrift Supervision formally preempted federally chartered banks (Saving and Loans) and their operating subsidiaries from state mortgage regulations in 1996. In 2004, at the height of the boom, the OCC followed suit (William and Bylsma, 2004, Dagher and Fu, 2016). Around that time the FDIC was also considering the pre-emption of host-state laws on state banks (FDIC, 2005). According to the nonpartisan Center for Responsive Politics, mortgage bankers and brokers invested nearly $\$ 847,000$ into Bush's re-election campaign in 2004, more than triple their contributions in 2000 (Becker et al, 2008).

\section{I think we will look back in 10 years' time and say we should not have done this but we did because we forgot the lessons of the past,}

\footnotetext{
${ }^{31}$ See,e.g. Reiss, 2005, Gerardi et.al, 2008, Mian et.al, 2008, 2010, 2014, White, 2009, Demyanyk and Hemert, 2011, Mian and Trebbi, 2013

${ }^{32}$ The Responsible Lending Act which was proposed in 2005 sought to "preempt state mortgage laws with a federal standard". The Act did not pass. In 2005 Rep B. Miller introduced the Prohibit Predatory Lending Act (2005) which aimed at "preventing abusive lending while preserving access to credit", but this bill was never voted on. Related to the oversight of the GSEs, a congressional majority, made of both parties consistently rejected amendments aiming at constraining GSEs balance sheets and limiting their systemic risk. Mian et al (2012) present a nice set of evidence showing how constituents interests and special interests helped to shape government policies that encouraged the rapid growth of subprime mortgage credit.
} 
and that that which is true in the 1930's is true in 2010.

Senator Byron L. Dorgan, November 1999, on the repeal of the Glass-Steagall Act.

The era leading to the financial crisis saw an increased deregulatory stance of the financial markets and a soldifying philosophy of light-touch regulation. There is a consensus among economists that the Riegle-Neal Interstate Banking and Branching Efficiency Act of 1994 was a positive development, allowing banks to diversify away risks. However, opinion remains divided on many of the deregulations that followed since, at the very least with the benefit of hindsight. Starting in the 1980s the Glass-Steagall Act came under pressure (Kaufman and Mote, 1990). The Glass-Steagall Act was passed in 1933 in response to the failure of the banks following the Great Depression. Many believed these investment banking activities caused a conflict of interest and increased the risk of bank failures. ${ }^{33}$ The pressure to reinterpret and repeal the Glass-Steagall Act intensified during the second half of the 1990s. This can be attributed to the recent benign experience with expanded bank activities, the role of technological advance in facilitating synergies across businesses (Barth et al., 2000), as well to pressures from industry lobbies (Rowe and Guenther, 1998). In 1999, the Act was repealed, with support from Fed Chairman Greenspan, Treasury Secretary Rubin, his successor Lawrence Summers, and with a relatively large majority in both the House and the Senate.

Toward the late 1990s, the head of the Commodities Futures Trading Commision (CFTC), Brooksley Born, has expressed discontent with the lack of oversight on over-the-counter (OTC) derivatives and communicated the potential dangers to the Administration with the suggestion of seeking public opinion on the matter. The Treasury secretary, Robert Rubin, expressed dismay at her suggestions, arguing that markets would be petrified and that the CFTC oversight would create uncertainty over trillions of dollars of transactions (see, e.g., Faiola et al, 2008). ${ }^{34}$. The Fed Chairman Allen Greenspan and the head of the SEC Arthur Levitt were also adamantly opposed to regulating the OTC market. Brooksley Born eventually resigned in 1999 but the fear of regulatory oversight led markets to lobby for a law that would protect OTC from the CFTC and the the Commodity Exchange Act (CEA). In 2000, Congress passed the Commodity Futures Modernization Act (CFMA). The CFMA removed OTC derivatives transactions from all requirements of exchange trading and clearing under the CEA for eligible participants. ${ }^{35}$ This is another example where a regulator's effort

\footnotetext{
${ }^{33}$ Although some empirical papers do not confirm the perception that investment activities contributed to bank failures during the Great Depression (See, e.g., Puri, 1996, Kroszner and Rajan, 1997).

${ }^{34}$ See also an article by the Project On Government Oversight on the political economy of the CFMA: http://www.pogo.org/blog/2014/04/how-the-clinton-team-thwarted-effort-deregulate-derivatives.html

${ }^{35}$ The market was therefore exempt from the CEA's capital adequacy requirements, reporting and dis-
} 
(Brooksley Born) backfired, as we saw previously. According to scholars and policy makers the CFMA transformed the U.S. financial system. Stout (2011) argues that the CFMA gave legal certainty not only to speculative interest swaps but also to virtually all other OTC financial derivatives. Between 2000 and 2007 the OTC market (in notional amount outstanding) grew exponentially (See, e.g., Heckinger et al, 2013). Following the 2008 crisis, many economists and policy makers, including earlier opponents of OTC regulations such as Greenspan (Andrews, 2008) looked back at CFMA as being one of the factors that contributed to the crisis (see, e.g., Acharya et al. 2009, Greenberger, 2010, Stout, 2011, Financial Crisis Inquiry Commission, 2011) by removing a multi-trillion dollar swaps market from regulatory oversight.

The move toward light-touch regulation in the financial sector can be also illustrated by Securities and Exchange Commission's (SEC) Consolidated Supervised Entities (CSE) program (see, e.g., Barth et al. 2012). This program allowed the Commission to supervise certain broker-dealer holding companies on a consolidated basis. The program was voluntary. A broker-dealer becomes a CSE participant by applying to the Commission for an exemption from the Commission's standard net capital rule. In a nutshell, in exchange for this voluntary supervision from which investment banks could opt-in and out and withdraw at their discretion (SEC, 2008), the CSE firms' broker-dealers are permitted to compute net capital using an alternative method that allowed them to increase leverage. ${ }^{36}$

This move was also widely seen as being one of the de-regulatory mistakes that set the stage for the crisis (see, e.g., Blinder, 2009). ${ }^{37}$ While some emphasize that this rule brought previously unsupervised entities under supervision, they do acknowledge that this was mainly a result of pressure by these entities themselves in order to escape more stringent regulatory threats by the European Union (Sirri, 2009). In other words, CSE allowed U.S. headquartered global investment banks to exploit a regulatory loophole in the EU's financial regulatory framework (Labaton, 2008), which amounted to a government-sponsored regulatory arbitrage. CSE came under heavy criticism after the crisis, including both from within the SEC and was discontinued in 2008 (see, e.g., SEC, 2009).

Following the housing bust, the ensuing financial crisis and Great Recession, there was almost a unanimous consensus, both within the policy and academic circles, that the crisis

closure, regulation of intermediates, self regulation and other regulations that address fraud, manipulation and excessive speculation. Eligibility of a participant required a total assets in excess of $\$ 10$ million. The notional value of the derivatives market at the time amounted to around $\$ 80$ trillion.

${ }^{36}$ A figure that was highlighted by Susan Woodward, a former SEC chief economist, at the annual meeting of the American Economic Association in 2009, suggest that the rule allowed investment banks to increase leverage from 1:12 to 1:33.

${ }^{37}$ See also a similar opinion by Simon Johnson, a former chief economist at the IMF, in a discussion with EconTalk at: http://www.econtalk.org/archives/2011/11/simonjohnson ${ }_{o} . h t m l$. 
called for a major reform of the U.S. financial system. The result was the Dodd-Frank Act (DFA), enacted in 2010, which was the most far-reaching overhaul of financial regulation since the 1930s. Much has been written about DFA both in the economic (see, e.g., Acharya et al, 2011, Kroszner et al., 2011, Schultz et al., 2014) and legal literature (see, e.g., Skeel, 2010, Wilmarth, 2010, Coffee, 2011). The reaction to the Act was mixed. Opinion remains divided on the extent to which the DFA addresses the roots of the crisis and whether it can prevent the recurrence of similar crises. While many scholars and policy makers pointed to missing element in DFA (see, e.g., Wilmarth, 2010, Gorton and Metrick, 2011) many critics also saw the DFA as an excessive regulatory reaction to the crisis that created a plethora of regulations and agencies. The financial system in the US was seen by some as over-regulated. For example, a February 2012 issue of The Economist which read: "Overregulated America." But the concern over the nearly 2300 pages (see, e.g., Kane, 2012) is not only due to its length (which dwarfs the previous financial reforms combined), but also its scope. As Jonathan Macey of Yale Law School puts it: "It is an outline directed at bureaucrats and its instructs them to make still more regulations and to create more bureaucracies." As of end of 2015, 267 of the 390 total required rules have been met, while 40 have been proposed but not implemented and 83 have not yet been proposed..$^{38}$

Among other actions, DFA overhauled the oversight and supervision of financial institutions, provided a new resolution mechanism for large financial companies, and created a new agency responsible for implementing consumer financing laws, the Consumer Financial Protection Bureau (CFPB). In addition, the Act introduced more stringent capital requirements, and tightened regulation of credit rating agencies. The Act also created a governing body to oversee the various regulatory agencies. On the mortgage and securatization front, the CFPB introduced a comprehensive reform of the mortgage market, setting out detailed standards and requirements. ${ }^{39}$

One might argue that the political repercussions from the Great recession can be felt until today. Immediately after the financial crisis, the incumbent Republican Party, lost a significant number of Congressional seats as well as the presidency. There is no doubt that the economy was a key factor in these elections. Following the crisis, the U.S. has witnessed an unprecedented political polarization which can be illustrated with the rise of the Tea Party and the Occupy Wall Street movements. The Tea Party movement was adamantly opposed to government transfers and taxation and government role in regulating the economy. The Occupy Wall street revolt consisted of a wave of protests against economic inequality and

\footnotetext{
${ }^{38}$ see DavisPolk's progress report: https://www.davispolk.com/Dodd-Frank-Rulemaking-ProgressReport/

${ }^{39}$ These reforms have been executed by the newly created Consumer Financial Protection Bureau.
} 
the political influence of corporations, especially financial firms.

Many, saw the DFA as an excessive legislation that would hurt growth. The republican nominee in 2012, Mitt Romney, ran on a platform that promised the repeal and replacement of DFA. Based on YouGov and other polls, however, more people favored financial regulation in 2012. The popularity of financial regulation started to decline shortly after, as the economy continued to recover (YouGov Polls). The Trump administration has vowed to roll back many of the key regulations in DFA, something that has been strongly signaled by an executive action, and followed by later actions that I will discuss shortly in Section 4. Commentators argue that the CFPB is likely to be severely affected by this new deregulatory wave. ${ }^{40}$

\subsection{Spain's Housing Boom and Bust}

Together with Ireland, Spain stands out among the Eurozone countries as having experienced a stupendous housing boom during 2000-2007 period. Based on OECD data, real house prices doubled during that period. The housing boom was accompanied by a massive increase in construction. The pace of construction doubled between 1998 and 2008 and the share of construction in GDP increased by 4 percentage points, reaching 10.7 percent in 2008.

The main drivers of the boom were the usual suspects: the low interest rate environment after becoming part of the Eurozone, demographic factors including a high immigration level (see, e.g, Gonzalez and Ortega, 2013), and (local) government sponsorship (see, e.g., Fernandez-Villaverde et al., 2013). Our focus is on the latter. The literature on the Spanish crisis point to a strong and clear political sponsorship of the housing boom, just as we have seen in other episodes. The Spanish bubble stands out in two aspects. First, the politicization in Spain happened at the regional level. Second, the politicization was so conspicuous that it can be hardly be missed by any account of the boom.

The 1980s witnessed a period of financial liberalization and reform in most advanced and some emerging markets around the word. Spain was not an exception and had its own string of financial reforms during the 1980s. However, as Perez (1997) argues in her book on the subject, the driving forces in Spain were less related to international market forces or the process of democratization. They were rather the culmination of a process of competition and bargaining between state elites and the private banking sector.

When it comes to housing, the Spanish government has long encouraged homeownership, which explains the fact that its homeownership rate is one of the highest in the world. Pre-boom Spain homeownership rate was already around 80 percent (Belsky and Retsinas,

\footnotetext{
${ }^{40}$ http://www.washingtontimes.com/news/2017/feb/5/trump-targets-cfpb-in-plan-to-unravel-doddfrank-a/
} 
2004, Andrews and Sanchez, 2011) compared to a homeownership rate of 70 percent in the U.S. during that period in the late 1990s. The pro-homeownership policies date back to the Franco regime when homeownership and urbanization were thought to help defuse the social discontent (Belsky and Retsinas, 2004, Marquez and Naredo, 2011). A series of reforms have further encouraged mortgage credit and ownership during the 1980s and the 1990s. The liberalization also allowed commercial banks to enter the mortgage market more forcefully and offer mortgages of variable interest rates at longer maturities.

During the 1990s this sponsorship intensified when the center-right People's Party (PP) government offered fiscal subsidies to homeownership (Alberdi and Levenfeld, 1996, McCrone and Stephens, 1996). According to Dellepiane et al. (2011), the effective subsidy on house purchase was U-shaped, benefiting disproportionally households on the tail ends of the income distribution. While some reforms attempted to address this issue, the policy remained biased toward ownership, new development, and construction. The favorable tax treatment for home-ownership was also extended to second homes during the 1980s (See, e.g., Santos, 2014), while the tax deduction for rentals was eliminated toward the end of the 1990s. When in 2004, the prime minister, from the Spanish Socialist Workers' Party (PSOE), was advised to reduce these fiscal incentives, he resisted due to political considerations (Montalvo, 2007). These incentives were later withdrawn after the burst of the bubble.

While the federal government had its own contribution to the housing boom, real estate policy was very much a local issue. The Spanish Cajas were at the epicenter of the housing bubble in Spain, similar to the Jusens in Japan and the S\&Ls in the U.S. during the 1980s.

The cajas are deposit taking institutions, similar to saving banks except for the fact that their profits are channeled into a foundation with socially oriented projects. Over time, they became a political tool. They were forced to invest in public debt or state owned enterprises. A 1985 law transferred the control of the cajas to the regional governments (See, Fernandez-Villaverde, Garciano, Santos, 2013, and Santos, 2014). Their credit then became increasingly directed to politically motivated projects. In fact, many of these cajas were headed by politicians who stepped down from public service. ${ }^{41}$ What further spurred their growth was a law passed in 1988 that allowed them to branch out into other regions (Alma-Sabater et al., 2013). Illueca, Norden, and Udell (2008) find that the cajas were more likely to open new branches and extend new loans in provinces that were politically aligned. Cuñat and Garicano (2009) show evidence that cajas who were run by a previously

\footnotetext{
${ }^{41}$ Perhaps Bankia offers the perfect example of how political influence led to a deterioration of the governance of cajas and the explosion of lending. The bank was formed by the merger of two cajas: Caja Madrid and BancaCaja. Fernandez-Villaverde et al. (2013) discusses how meddling by politicians led to the expansion of both cajas since the late 1990s before their merger. For example, during the boom, Valencias previous finance minister, who drafted a law regulating local cajas, became the president of Bancaja.
} 
a political appointee have had significantly worse performance. They also show that the higher education level and banking experience of the chairman, the better they performed based on measures of delinquent loans during the crisis.

In principle, the regulatory and supervisory powers were shared amongst the the central government, the Bank of Spain, and local authorities. However, there is little evidence of a significant intervention by either the central government or the Bank of Spain to address the deteriorating governance during the boom or to curb their credit growth.

Another major development that is key to understanding the housing boom, was the decision by the constitutional court in 1997 to give the regional government complete control over zoning regulation. Therefore, by the late 1990s, regional government had control over the supply (through land availability) and demand (through credit supply) of housing. If history from previous bubbles is any guide, and this paper argues that it is, politics and real estate are an explosive mix. This new environment offered a win-win dynamic for developers and local politicians. Sole-Olle and Viladecans-Marsal (2012) provide empirical evidence of the political dimension of land development, showing that weaker political competition was associated with more land development. Developing new land was a lucrative business for both, and corruption made it even more so (see, e.g., Jimenez, 2009). The increase in corruption was so severe that Spain's ranking on the Transparency International (TI) corruption perception index dropped from 146 to 180 between 2004 and 2008. According to TI this was primarily due to cases of urban planning corruption (Jimenez, 2009). The committee on Petitions of the European Parliament (European Parliament, 2007) said that since 2003, petitions have not stopped and that "In no other EU country are citizens' rights to their property abused in this way to this this extent."

Lending for construction and development grew from 8 percent to nearly 30 percent of GDP between 1995 and 2005 and mortgage lending went from 17 to nearly 50 percent of GDP (Beltran et al., 2010). Akin et al (2014) analyze the mechanism through which mortgage credit was extended to a risky category of buyers despite regulatory LTV restrictions. They find evidence that the cajas encouraged real estate appraisal firms to induce an upward bias in prices (around 30 percent).

Concerns about the housing bubble were expressed early on. A 2003 report by the European Commission warned about a housing bubble. Spanish authorities, particularly the independent central bank, began expressing concerns about the bubble as early as 2003. Several studies by the central bank indicated overvaluation. However, no real policy response came from the government. There was no appetite to address the bubble ahead of the 2004 elections were held in 2004, so (Santos, 2014). The central bank, on the other hand, introduced dynamic provisioning due to concerns of overheating (see, e.g., Saurina, 2009), 
which has helped cushion the early crash, but was not sufficient to prevent a crisis.

With the onset of the crisis the Spanish government intervened forcefully to stabilize the financial sector. A debt guarantee program was put in place following Lehman's collapse. This was later followed by numerous banking interventions, including capital injections in the first quarter of 2009, and the creation of the FROB, a fund for orderly bank restructuring to channel public funds to aid the restructuring of the banking sector. Banking interventions continued well into 2012. The crisis resolution is well covered in the existing literature (e.g., Jackson, 2009, IMF, 2012 and 2014b, Crdenas,2013, Santos, 2015), but our focus is mainly on changes in the regulatory framework.

The regulatory response to the crisis was decisive. Most importantly, the cajas, which were at the epicenter of the crisis, saw their institutional framework completely overhauled. This took place through several steps. The governing bodies of the cajas were reformed and stricter criteria were introduced for representatives of regional governments (IMF, 2012). Elected officials were prohibited from serving in the governing bodies. More importantly, and for the first time since their inception, the cajas transferred their banking business to newly formed commercial banks, leading to a separation between their banking business and their social activities. These new commercial banks were put under the exclusive supervision of the Bank of Spain and were able to raise capital. Financial reforms did not stop at the cajas, they touched on aspects related to bank resolution, regulation, and supervision. Bank capital requirement was increased, the supervisory power of the Bank of Spain was strengthened and its on-site continuous monitoring was extended to all significant Spanish banks. Just like we have seen in virtually every episode, banking supervision was overhauled and the supervisory authority was reorganized.

The political repercussions of the crisis were significant. In Spain, two political parties dominated the political scene since the early 1980s: the left-leaning Spanish Socialist Workers' Party (PSOE) and the conservative People's Party (PP). The PP was in power during the early stages of the boom, but lost in the general election of 2004. The PSOE, which was in power between 2004 and 2008, was severely affected by the crisis receiving its lowest share in the total vote since Spain's transition to democracy. More significantly, the crisis had a profound impact on the Spanish political landscape. Since the last election in 2011, and as the Spanish and European crisis deepened, the combined share of the two parties declined with the rise of Podemos, a third party founded in 2014 in the aftermath of protests against inequality and corruption. In the latest general election in 2016, the combined vote of both parties (PP and PSOE) was around 55 percent-down from an average of of 80 percent in the previous five elections. Some commentators see the two-party system as the latest victim of Spain's financial crisis due to the protracted recovery in employment and a string of political 
corruption scandals (e.g., Financial Times, 2015).

\section{Discussion}

The analysis of financial regulation over some of the most infamous financial crises in history reveal similarities that are hard to ignore. This section offers a summary of these commonalities, provides further analysis as well as additional illustrative examples including limited empirical analysis that comes with several caveats. This section also takes a first stab at formulating theories that could rationalize the stylized patterns.

\subsection{The regulatory pendulum}

On January 25, 2017, the Dow Jones Industrial Average crossed the symbolic 20,000 mark for the first time, which stands around 40 percent above its peak during the housing boom. The following week, on February 3rd, President Trump signed an executive order that was broadly advertised and received as a first step toward meeting his campaign pledge to "dismantle the Dodd-Frank Act and replace it with new policies to encourage economic growth and job creation." 42 On June 8th, The House of Representatives passed a legislation entitled the Financial Choice Act which erases core financial regulations in the Dodd Frank act (DFA). Most analysts argue that the Choice Act is unlikely to pass the Senate in its current form. One June 12th, the Treasury released a report, in response to President Trump's executive order, that proposed sweeping reforms to the DFA that go in the direction of reducing the burden of regulations on banks and reducing the powers of the Consumer Financial Protection Bureau created under DFA.Therefore all evidence, including soft information related to the recent appointments of regulators, suggest that we are entering a de-regulatory phase. ${ }^{43}$

The Dodd Frank Act was signed into law in July of 2010, around two years after the full blown financial crisis. As discussed earlier, the law sought to undo some of the deregulatory steps taken over the previous decade, and create additional rules that aim to enhance financial stability.

This regulatory pendulum that we have been witnessing is not only interesting in itself, but also because it has been a regular feature of financial booms and busts. The DotCom boom of the 1990s in the US coincided with a move toward significant deregulation

\footnotetext{
${ }^{42}$ The language of the Executive order itself did not mention the Dodd-Frank Act, it simply directed Federal agencies to examine financial regulations and report as to whether they are consistent with Core Principles which include economic growth and international competition.

${ }^{43}$ See, e.g.,Financial Times, 2017
} 
of the securities industry. This trend reversed following the crash with the passage of the Sarbanes-Oxley Act and other regulatory and supervisory actions.

In similar ways, the 1929 crash happened in an environment where laissez-faire was the mantra of the day. This period witnessed a deregulatory stance that increased competition in the banking sector, reduced the regulatory burden on banks and weakened existing supervision. Needless to say, the ensuing Great Depression lead to a plethora of financial regulations that shaped US financial system for decades.

Pro-cyclical regulations are not a unique feature of financial regulation in the United States. This paper presented episodes from the South Sea Bubble to the Spanish crisis of the 2000s, showing pro-cyclicality as a common feature during financial boom-bust cycles.

It is worth highlighting some of the commonalities and differences in regulatory stances during some of the modern international crises reviewed in this paper. The political context, particularly, the political stimulus and sponsorship of the booms will be left for the next section. In almost all cases presented in this paper, the financial boom came at the heels of a period of financial deregulation. With the exception of Spain, deregulation happened over a relatively short period of time, intensifying within five years of the crisis. For example, Japan, Korea, and Sweden lifted banking regulations that were present for decades. One can argue, based on the evidence presented in this paper, that in all but the Swedish case, de-regulation was not simply a matter of liberalization and modernization. A light touch approach to regulation replaced the existing regulatory framework and led to decreased supervision and the rise of an informal system of regulations which often led to corruption. This can be seen very clearly during the Japanese, Korean, and Irish booms. In Spain, a series of deregulations at the federal level gave the regional governments the power to regulate land usage and local banks. This in turn lead to an informal system of regulation that reduced checks and balances, encouraged construction and lending, and led to an episode of significant increase in corruption. Just as in the US and in England, warning signs about the unsustainability of the boom and the instability of the banking sector were ignored in almost all cases and did not lead to a supervisory response until after the crash. Governments responded to crises with an almost complete overhaul of the regulatory and supervisory framework. The regulatory backlash did not only consist of new regulations and financial bills, but also included in most cases the creation of new institutions and bodies to supervise banks. The response to the crisis in Sweden, while also significant in some aspects (since it led to the independence of the Riksbank), was more muted on that level, possibly for two reasons. First, the crisis was to a great extent the result of macroeconomic imbalances and the unsustainability of the exchange rate, as discussed in the literature. Second, while Sweden liberalized its banking sector, the boom did not lead to a decay in supervision nor 
to a rise of an informal system of regulation. In other words, the strong level of governance and low corruption in Sweden has protected existing institutions. When economists refer to the risks of rapid liberalization, the case of the Nordic economies in the 1990s offers a good example. As for the other episodes discussed in this paper, they show that there is often much more to deregulation than simply modernization. This can be better understood when looking at the political environment in which these booms took place which I discuss in the next section.

As mentioned earlier, it is a challenging task to qualify and quantify financial regulations, although the literature has made significant progress on that level in recent years (see, e.g., Barth et al., 2012, Groll et al., 2017). This is why this paper relies on a wealth of scholarship to understand the regulatory stance during each episode. Therefore one has to be careful about trying to quantify regulation based on a specific measures, notwithstanding the difficulty in gathering such data. When it comes to financial supervision, data on the budget of financial regulators can be obtained in some instances, however, such data have both quantitative and qualitative limitations. For example, as we saw during several episodes, the financial regulatory structure is subject to changes, especially, but not only, following crises. Also, the fact that different tasks of regulating the financial sector is spread out across several agencies each of which can be involved in different activities related to the financial sector makes quantifying the degree of supervision particularly hard. Most agencies are at least partly dedicated to bureaucratic tasks such as processing filings by corporations and banks which are likely to correlate with the cycle but do not reflect the extent of supervision that is discussed in this paper. With these many caveats in mind, Figures 1 to 3 plot the financial regulatory budget and staffing over the cycle. Figure 1 shows the total expenditure on financial regulation by the U.S. government from a study from the Weidenbavm Center (Washington University) and the Regulatory Studies Center (George Washington University) derived from the Budget of the United States. Looking at staffing first, we see a major jump toward the late 1980s and early 1990s, which is directly linked to the resolution of bank failures from the Saving and Loans crisis that led to an increase in the staffing at several agencies, particularly at the FDIC following bank and failures. After this period, staffing was on an almost continuous decline returning to its mid-1980s levels toward the mid-2000s, at the height of the housing and credit boom. The trend clearly reversed following the financial crisis of 2008. The budget allocated to these agencies (in constant dollars of 2000) is less volatile. It shows a continuous increase since the 1960s, accelerating following the S\&L crisis, but, surprisingly, reaching a plateau between the mid 1990s to the mid to late-2000s. It was only after the Financial Crisis of 2008 that we see a rapid acceleration, consistent with the regulatory backlash from the crisis. In other words, both figures show a countercyclical 
patter consisternt with a procyclical regulatory and supervisory stance. When it comes to the Dot-Com episode, which was localized to the securities market, it is more appropriate to focus on the SEC's budget. This is shown in Figure 2 which plots the budget of the SEC together with the S\&P index. Between 1985 and 1995 the SEC's budget was on a steady increase. Yet, just around the time when the stock market was booming at an unprecedented pace since the Great Depression, the SEC's budget (in real terms) plateaued and remained on at roughly the same level until the crash. It then of course experienced a massive growth following the crash. Figure 3, presents a panel of four figures on budgetary cost of financial regulators from other episodes discussed in this paper. With the exception of the data from Japan perhaps, these series come with several caveats. In the case of of Japan, historical time series are available for the total number of staff at the Ministry of Finance, which was the main regulator of financial institutions prior to the crisis and until 1998. What we see is a significant decline in human resources during the boom period, as discussed in Amyx (2004). In the case of South Korea we are constrained by data availability and comparability. Data on staffing cost at the Central Bank are only available starting in 1995. They included a sub-category for financial regulation, which is plotted between 1995 to 1998. In 1998 a new financial regulation agency was created, the Financial Supervisory Service (FSS), to help supervise the financial sector. While the central bank retained some of its supervisory authority, the data breakdown between total staffing and staffing dedicated to financial regulation are no longer available after 1998. Therefore the pre- and post-1998 data are not comparable in levels, but the growth rates illustrate what has been repeatedly mentioned in the literature and by policy makers on financial regulation in South Korea during that episode. Note that the figures are plotted again private credit growth since the stock market was declining several years prior to the crisis. This is one of the few episodes where the stock market and private credit were not highly correlated. It is a well known fact that South-East Asian crisis, including the one in South Korea, happened in 1997. In the case of Spain, we only have access to the budgetary cost of total human resources at the central bank (BdE). In the absence of literature on the topic, and given the magnitude of the drop between 2004 and 2005, one has to be cautious in fully attributing this to a regulatory cycle story. While the data show a reversal in the trend following the crisis, as we see in every episode, this trend seem to have been short-lived. In the case of Ireland, staffing cost (in real terms) has been continuously on the rise at the Central Bank, and we do not see a slow-down in resources during the boom. In fact we see an uptick in 2004 following the creation of the Irish Financial Services Regulatory Authority (IFSRA) in 2003. As mentioned earlier, the creation of IFSRA came as a response to financial scandals. The data from Ireland illustrate the drawbacks from trying to quantify financial regulation; not 
because it does not fit the expected patterns, but instead because, during the boom period, the government itself became vocal about its adoption of a light-touch approach to financial regulation (as discussed and referenced earlier). With such a philosophy toward financial regulation, it is not clear whether staffing of financial regulators would be a good indication at all of the intensity of financial regulation. This caveat, as discussed earlier, applies to all the data presented here, and not just the Irish case.

\subsection{Political economy elements of the cycle}

The pro-cyclicality of regulations happened across time and across several advanced economies with diverse forms of democracy. Comparing these episodes, the paper finds strong similarities in the political environment during the booms and the political repercussions from the subsequent crises. Politics and financial regulations were entwined in each of these cases. These deregulatory and re-regulatory policies happened at a high political level rather than at a bureaucratic level. Three stylized patterns emerge from the analysis. First, for the majority of the booms, ruling governments have been strong proponents of laissez-faire policies, which tended to ease regulation on the financial sector. At the same time, they embraced credit subsidies, a policy that deviated from the laissez-faire doctrine. Second, the paper finds that, in many instances, a deterioration in governance can be observed, specifically, an increase in symbiotic relationships between politicians and financiers, as well as increase in corruption. Third, the ruling party finds itself swept from power by convincing margins following a crash. The political ramifications of the crises cannot be underestimated; financial crises have often generated significant political change and intense polarization (see, e.g., Mian et al., 2014). Elected governments in the aftermath of the crash usually ran on a platform that embraces financial regulation and sometimes displays hostility towards the financial sector. The question regarding the extent to which the re-regulatory wave under the newly elected government is often a knee-jerk populist reaction (as it was argued by some following some episodes) or a well thought out process (albeit, naturally prone to errors) that is is based on careful diagnostics, or a mixture of both, is subject to debate. This difficult question is beyond the scope of this paper.

What the data from the most recent wave of crises seem to suggest, is that the fiscal costs of the crisis were a significant predictor of the extent of the regulatory backlash. This is illustrated in Tables 1 and 2 based on data from The Bank Regulation and Supervision Survey, carried out by the World Bank (see, for a reference, Barth, Caprio, Levine, 2012, Cihak, Demirguc-Kunt, Martinez Peria, and Amin Mohseni-Cheraghlou, 2012). The survey is taken in 2001, 2003, 2007, and 2011. The regressions and controls are discussed in the 
tables' footnotes. Since the regressions include country fixed effect, they control for the cross-sectional variation in the level of regulation across countries, the optimal level of which can vary across countries (see, e.g., Dagher, Dell'Ariccia, Laeven, Ratnovski, and Tong, 2016). Therefore the results seem to suggest that the regulatory backlash was at the very least influenced by the economic cost of a banking crisis which results in frustration by the average citizen (median voter). But such evidence, on its own, is perhaps not sufficient to answer the above question. An empirical investigation of this matter is limited due to lack of comparable measures of voter sentiment in a cross-country setting. ${ }^{44}$

The first two political stylized patterns are present in most booms discussed in this paper, with the exception of the Swedish episode (Section 3.5). For example, in the two early crises in England discussed in this paper, the South Sea Bubble (Section 3.1) and the 1825 crisis (Section 3.2), politics tied in strongly to financial policy. In both cases, members of the parliament were heavily invested in the boom companies and provided protection to these companies through forbearance, deregulation, and regulatory arbitrage (Carswell, 1993; see Dawson, 1990; Chancellor, 1999). In the US, the Roaring 1920s happened in an environment that vigorously supported laissez-faire policies. President Coolidge (1923-1929), who is known for his pro-business policies, took a dim view on government regulations of businesses and appointed regulators who subscribed to his views (Ferrell, 1998). Yet, there was a strong political push for homeownership (Hoover, 1929; Hoover, 1922). An increase in symbiotic relations between politicians and bankers is documented in the literature (White, 1983, 2009) and the state of Florida boom offered a prime example (Vickers, 1994; White, 2009). Laissez-faire doctrine and skepticism about regulations saw a revival in the 1980s during the Ronald Reagan administration (See, e.g., Jacob, 1985, Niskanen, 1988, Sherman, 2009). The move toward light touch-regulation, and financial deregulation, continued in the 1990s after a setback following the Savings and Loan crisis (which led to a massive increase in the number of financial regulators and supervisors). The trend was coupled again with a move towards subsidization of the housing market, which started under the Clinton Administration. These trends intensified under the George W. Bush administration. The literature points to the role of private interests behind both of these trends (Kolodny 2011; Stout 2011; Mian et al 2008 and 2010; Igan 2014). Section 3.9 presents examples of warnings by high-level regulators that went ignored by the administration.

The extent to which the incumbent government in Japan, during the boom, was freemarket leaning party is not clear-cut since in Japan, a single party (LDP) held power during the post-war era. What we know for certain is that the political sponsorship of the boom

\footnotetext{
${ }^{44}$ One might be tempted to use electoral results as a measure of voter frustration but this is fraught with significant limitations.
} 
and the deterioration in governance were a hallmark of thsis episode. In Japan, financial deregulation led to a rise in informal system of regulation, under which networks between banks and the government thrived (See, e.g., Amyx, 2004). With intensified informal regulation and increased political interferences, the Ministry of Finance found its ability to regulate financial institutions severely diminished towards the end of the 1980s (See, e.g., Patrick, 1998, Karaki, 2000). A prime example of this is the politicization of the Jusens, which contributed substantially to the boom in both residential and the commercial sector (See, e.g., Iwamoto, 2006). Additionally, the government unveiled in the mid 1980s a major reconstruction plan to boost commercial real estate in Tokyo, which also influenced the markets expectation regarding land prices (Cutts, 1990). Amidst booming stock and land prices, interest rates were lowered significantly by the Bank of Japan, an institution that was subject to political discretion at that point in time (See, e.g., Horrowitz and Heo, 2001). As far as corruption goes, it was omnipresent during the boom period, as is well discussed in the literature leading to a litany of scandals that embroiled politicians from all parties (See, e.g., Nester, 1990, Christensen, 1998, Blechinger, 2000, Rosenbluth and Thies, 2001). ${ }^{45}$

As economic growth began to slow down in South Korea the early 90s, Kim Young Sam's government implemented the 100-day plan package to stimulate the economy. The government influenced lending decisions through the Industrial Rationalization Loans, which required banks to allocate fixed proportions of marginal loans to the small and medium-sized enterprise sector, 56 percent of which were non-performing at the end of 1996 (See, e.g., Barth et.al, 1998). The government also spurred credit directly through the Korean Development Bank (KDB), one of the largest lenders, which increased its credit supply by around 20 percent a year between 1994 and 1996. The close-knit relationships between politicians and banks and large companies, particularly the Chaebols, is also well discussed in the literature (See, e.g., Haggard and Mo, 2000, Haggard and MacIntyre, 2001, Kihwan, 2006). This allowed Korean banks to continue lending to the Chaebols, which had an alarming level of indebtedness. The government also facilitated the increased hold of chaebols on non-bank financial intermediaries (Leipziger, 1998). Regulatory oversight eroded significantly in light of the close ties between businesses and politicians. Influence peddling by large companies to maintain credit lines during the boom became a characteristic trait of this episode, leading to multiple scandals. ${ }^{46}$

The political stimulus to the financial boom in Ireland was very pervasive as discussed in more detail in Section 3.8. The incumbent pro-market government (Fianna Fail), moved

\footnotetext{
${ }^{45}$ One of the most prominent scandals was the Recruit Scandal, which led to the resignation of several high-ranking government officials.

${ }^{46}$ One prominent example is the Hanbo scandal, which involved key officials from the Ministry of Finance (Haggard and Mo, 2000).
} 
steadily and increasingly toward light-touch regulation. As discussed earlier, it is well acknowledged that the so-called principle-based regulation meant little to no regulation. At the same time, the government gave a strong stimulus to the financial sector as well as to the already booming housing sector through fiscal incentives and subsidies for developers and real estate investors. The role of private interests, political motivations, as well as outright corruption, are well documented in the literature as discussed in Section 3.8 and in the literature (Norris and Redmond, 2005; Dellepiane, et al., 2011; Menelaos and Norris, 2011; Clarke and Hardiman, 2012; MacLaran and Kelly, 2014). Up until 2007, in the lead up to the elections, political parties campaigned on promises to abolish the stamp duty tax on house purchases (Whelan, 2014).

A similar scenario played out in Spain, where local governments had a direct hand in the booming mortgage lending by the cajas and the tremendous increase in construction by the politically influential developers (e.g., Illueca, Norden, and Udell, 2008; Fernandez-Villaverde et al., 2013). Just as in the case of Japan, as well as some of the historical episodes, this episode offers many examples of politicians sitting on the board of banks that were heavily involved in risky lending. During that period, corruption was rampant. Between 2000 and 2008, 676 out of a total of 8116 Spanish municipalities reported instances of urban planning corruption (Robles-Egea and Delgado-Fernndez, 2014).

The third stylized fact that the section highlights relates to the political ramifications of these financial crises. Incumbent politicians or parties have lost power following all but one episode. The crisis that followed the South Sea Bubble led to the expulsion and prosecution of several MPs, and cabinet members including the Chancellor of the Exchequer. The cabinet member who was the most vocal skeptic of the bubble, Robert Walpole, became the most prominent political figure and de facto the first and longest serving prime minister of England (Paul, 2009). The 1825 crisis stands out as being one of two cases, studies in this paper, where the political ramifications were muted and hard to assess. During that period, the issue of Catholic emancipation dominated the political scene, particularly during the 1826 elections, eventually leading to the Roman Catholic Relief Act of 1829.

Following the onset of the Great Depression in the US, Herbert Hoover, the Republican incumbent, lost his reelection bid in stunning terms, gaining Electoral College votes in only six of the 48 states, a ratio completely reversed from his dominating victory four years earlier. The Democrats, who believed in a strong role for the government, including in the area of economic and financial regulation, gained the presidency (the third time since the civil war) and both houses of Congress. They retained the presidency for the following 22 years. In a similar way, the US Great Recession of 2008-2009 had major political repercussions. The incumbent Republican Party lost heavily in the 2008 election, both in the presidential race as 
well as in the House and the Senate. The elected president, Barack Obama, ran on a platform that harshly criticized the excesses of Wall Street. More importantly, as mentionned earlier, the US witnessed a significant rise in political polarization that has not been seen in recent history as exemplified by the influential Tea Party and the Occupy Wall Street movements. The patterns outlined above can also be observed following international crises.

Political retribution happened with force in Japan when voters, shocked by the scandals, threw out the Liberal Democratic Party (LDP) from both houses, a party that had been continuously in power since 1955. In the 1993 election, multiple competing factions emerged within the LDP leading to the victory of an eight-party coalition headed by LDP dissident Hosokawa Morihiro of the Japan New Party (See, e.g. Nester, 1990, Shinoda, 1998, Cohen, 1999). The crisis immediately led to major political reforms that touched on all aspects of governance and policy-making. One notable example is the 1994 reform of the electoral system at the district level, which was implemented to replace the earlier system that was seen to be more prone to corruption and political influences by large corporations and banks (See, e.g., Rosenbluth and Thies, 2001).

The political ramifications in the case of Republic of Korea also deserve to be mentionned. The incumbent party during the boom was the Democratic Liberal Party, which was typically characterized as a center right party. They lost voter popularity shortly after the crisis, particularly when the economy had to be bailed out with a 58.4 billion loan from the International Monetary Fund (Kihwan, 2006). ${ }^{47}$ The Democratic Liberal Party, reinvented as the New Korea Party, merged with the United Democratic Party to become the Grand National Party in the lead up to the elections in 1997. During the elections of 1997, the reformed incumbent party lost to the newly formed left-leaning coalition headed by Kim Dae-Jung. Kim Dae-Jung had been in the opposition for a long time, and he was sometimes described as a populist figure (Haggard, 2000). Kim Dae-Jung initiated significant political reforms in the aim of improving governance and reducing bureaucracy, in addition to the financial reforms discussed in Section 3.6 (Haggard, 2000). To make the government more efficient, Kim Dae-Jung proposed an administrative reform to downsize the public sector, eliminating entire agencies and ministries (Haggard, 2000). A driving force behind these reforms was to improve transparency.

In post-crisis Ireland, the local election results of 2009 represented an emphatic rejection of an incumbent governments policies. ${ }^{48}$ Fianna Fail witnessed its worst historical electoral

\footnotetext{
${ }^{47}$ Korean Centre right party was formed by a set of multiple mergers - Roh Tae-woo's Democratic Justice Party, Kim Young Sam's Reunification Democratic Party and Kim Jong-pil's New Democratic Republican Party merged to form the Democratic Liberal Party. It was re-established as the New Korea Party (NKP) in 1995 (Kim, 2008)

${ }^{48}$ Kinsella and Kinsella (2009) argue that the government's failure to claim responsibility for the actions
} 
loss, losing 135 seats. In the first post-crisis general elections of 2011, Fianna Fail also suffered a crushing loss to a coalition of the conservative Fine Gael and smaller left-leaning Labor Party, which secured a historically large share (68 percent) of the parliament (See, e.g., Kriesi, 2012, Hardiman and MacCarthaigh, 2013). In light of the EU-IMF funding deal signed in the waning days of Fianna Fails government, the 2011 election witnessed multiple opposition parties perform well on the anti-bailout agenda (See, e.g., Hardiman and MacCarthaigh, 2013, Whelan, 2014). The newly elected government introduced sweeping administrative and political reforms driven towards a more efficient form of governance, which involved a centralized bureaucracy and higher accountability in public service (Hardiman and MacCarthaigh, 2013).

The political ramifications of the Spanish crisis were very significant, but took place over several general elections as the crisis that started in 2008 intensified over the next four years. Two major parties, the Spanish Socialist Workers Party (PSOE) and the conservative Peoples Party (PP) dominated Spanish elections over several decades, with a combined vote share consistently above 70 percent since 1993. The housing and financial boom happened under both parties. Following two years of severe economic contraction the incumbent left-leaning PSOE lost the election in favor of the PP. But the seismic shift in Spanish political landscape happened in the following years as the crisis intensified and GDP continued to contract. Spain saw the emergence of a new influential movement, the Indignados, which eventually led to the formation of the populist left-wing party, the Podemos (See, e.g., Cini and Borragan, 2016, Fenton, 2016, Mudde, 2016). In the 2015 and 2016 elections the combined vote share of the PSOE and PP dropped to historical lows while the Podemos (and in 2016 the alliance between Podemos and United Left) managed to garner around 20 percent of the votes. For the first time in Spanish political history elections and ensuing negotiations failed to

produce a stable governing coalition. The fact that members of both major political parties were implicated in corruption during the housing boom between 2000 and 2007 was patently an important contributing factor, and the opposition parties, particularly Podemos, ran on an anti-corruption platform (See, e.g. Jiménez, 2009, Jiménez and Villoria, 2012, Villoria et.al, 2013, Robles-Egea and Delgado-Fernández, 2014, Torreblanca, 2015, Sanders et.al, 2016).

\subsection{Potential theories behind these patterns}

The findings in this paper beg the question of why does financial regulation behave in such a way. The fact that regulation tends to be laxer during booms and stricter during that led to the crisis was a significant component of voters' frustration. 
busts seems, at least from an ex post perspective, inefficient. If financial regulation is indeed partly successful at curbing risk taking, and if, as many argue, this comes at a cost of tighter credit conditions, one might wonder whether financial regulation should instead be counter-cyclical.

To be clear, this question is far beyond the scope of this paper. The answer to this theoretical question is unlikely to be simple. This topic sits at the intersection of finance and politics, an area that needs to be tread cautiously, as one can infer from the literature review in section 2. Therefore, this question is left for future research.

Nevertheless, it would perhaps be useful to lay out some initial hypotheses based on the evidence presented so far. The following list is in no way comprehensive nor is it methodical.

One of the most conspicuous characteristics of financial booms is the optimism or even mania displayed by the market during such episodes. This has been discussed in many notable works about financial crises such as Kindleberger and Aliber (2001) and Reinhart and Rogoff (2009).

This observation is hard to ignore in any theory that aims to explain the pro-cyclicality of financial regulation. In the context of a highly stylized model, changes in sentiment can alone explain the cycle.

Let us assume that politicians share the same information set and expectations with market participants and voters. For the sake of simplicity let us also assume that optimism is inversely related to the subjective probability of a bad financial event. In other words, market sentiment simply reflects agents perception about the safety of financial innovation. Under these assumptions it is evident that the median voter and an honest politician would find it optimal to reduce costly financial regulations, which are perceived to reduce financial intermediation, under an optimistic scenario and increase regulation when pessimism sets in. Therefore, under such assumptions, financial regulation can be optimally (from an ex ante perspective) pro-cyclical. Note that this finding can also be obtained in models that weaken the assumption about the congruence of politicians (Almati, Dagher, and Prato, 2017). For the purpose of this section, I will quite arbitrarily label this mechanism as the "sentiment hypothesis," since the cycle is purely driven by changes in the sentiment of voters. In this context, the low frequency of these cycles can be reasonably attributed to a combination of Bayesian updating and collective memory loss. The above hypothesis assumes that voters have more confidence in finance during booms than during busts and a more favorable opinion of financial regulation during busts compared to booms.

Some statistics are available from the United States to shed light on this issue. The General societal survey asked participants their opinion about their confidence in banks and in big companies. The favorability is shown in Figure 4. This Figure shows several 
interestingly consistent patterns. First, confidence in banks plummeted during the last two banking crises, the SL and the Great Recession. The Dot Com bust led to only a temporary decline in confidence in banks, which is consistent with the view that confidence is affected by real performance, as banks were essentially left unscathed during that period. ${ }^{49}$ Second, confidence in banks peaked toward the height of both the dot com boom, around the repeal of Glass Steagall, and at the height of the housing boom. Third, one of the most interesting patterns is the relative performance of banks compared to big companies. The drop in confidence in large companies was very large and persistent following the Dot Com bust. This is both in line with the drop in the stock value of these companies and the numerous scandals that surfaced during the bust. The response by participants reflects real differences between banks and large companies suggesting that voters are relatively well informed about the big picture. ${ }^{50}$

Another hypothesis, which to some extent a special case of the 'sentiment hypothesis, would posit that the cyclicality of regulation can be due to voters wanting to get informed about the financial system and the level of regulation only after crises. And that, overtime, the interest in financial regulation wanes, allowing the latter to decay and for regulators to be captured by concentrated private interests. This can be labeled the news effect. This is quite equivalent to the assumption that as the collective memory of a crisis wanes voters gain more confidence in the system, thus adopting a hands-off approach to this issue. A long literature have examined the cyclicality of fiscal policy (see, e.g., Rogoff, 1990, Tornell and Lane, 1999, Talvi and Vegh, 2005, Alesina and Tabellini, 2005). One can put forth a similar story in which the politician can take advantage of asymmetric information to boost the economy and favor his re-election. The details of such theory would have to be hashed out more carefully to see whether it indeed holds under reasonable assumptions. What we do know is that unlike fiscal policy, financial regulation is at the very least more noisy and its effect can take place with a substantial lag. Therefore it is possible that politicians have strong incentives to deregulate toward the beginning of their tenure.

Voters understanding of the nature of asymmetric information and the incentives of politicians means that this and other hypotheses have to be put to the test in a model with non-naive voters.

In a recent paper on political credit cycles, perhaps one of few related papers, Villlaverde

\footnotetext{
${ }^{49}$ It is possible that this short-lived drop was due to September 11th, 2001.

${ }^{50}$ The presumed negative correlation between confidence in banks and support for financial regulation, which has good theoretical support, is harder to establish empirically due to lack of data. For example, in 2010, when confidence in banks was at its lowest, Dodd-Frank bill was not only more popular than other bills proposed around that time, but its approval was above 60 percent while the next most popular bill had an approval rate at slighty above 40 percent. Evidence stitched from different polls on the topic (see e.g. Bowman, ONeil, and Sims, 2015) also suggest that this assumption is reasonable.
} 
et al (2013) and other put forth a different theory. They start from the premise (which they show can be obtained from a model) that it is harder to distinguish between good and bad politicians during booms. In boom times both politicians look successful. During the bust, voters try to get more informed. It seems that, based on this theory, excessive booms, those that lead to a financial crash happen under less talented politicians. Bad politicians therefore deregulate, and good politicians re-regulate.

In a recent working paper (Almasi, Dagher, Prato, 2017) we combine a standard financial regulation model, in the spirit of Acharya (2009), with a plain vanilla voting model. The model inherently includes changes in expectations by voters. We show that even under asymmetric information, the voters expectations affect the regulatory cycle. Moreover, the model can produce an inefficient amplification of the regulatory cycle. An outcome of the model has the competent politician deregulating more than it is ex ante optimal during periods of optimism, and excessively regulating during busts. This is because a competent politician can afford to signal his competence at the cost of some inefficiency. Note that in this model, the more congruent the politicians are the more muted is this amplification mechanism. That is, these cycles are less likely to happen at a large scale in countries with less corruption and more accountability on politicians. This finding is consistent with the case of the Nordics, discussed earlier.

It might seem odd that I have not discussed the role of lobbyists thus far. It is evident from Section 3 that the booms were characterised by closer relationships between lobbyists and politicians. The institutions that arise from the ashes of the crisis go in the direction of weakening such links.

But before one attempts to significantly complicate the existing models, it is worth considering the possibility that the symbiotic relations between politicians and bankers in essence a political decision. Bankers have strong incentives to try to influence politicians and bankers at any point in time particularly at a time of increased regulation. However,the same signalling objectives that bring politicians to deregulate during boom could possibly explain their decision to form closer alliances with bankers. Similarly, the forces that lead to reregulation can lead them to distance themselves from bankers. Having said this, this does not mean that lobbies do not end up influencing the re-regulatory process, but it is possible that their relative influence is diminished post-crisis. This would not be inconsistent with the evidence presented in the paper.

What I presented above is definitely not an exhaustive list of contributing factors; the patterns presented here can be explored in future research. 


\section{Conclusion}

Financial crises are a recurring phenomena in market economies. An impressive body of economic research has been devoted to understanding these crises in the aim of making economies less prone to these enormously costly episodes. This literature saw a revival following the Global Financial Crisis. While there are various explanations to the roots of the crisis, the idea that more stringent financial regulation and supervision could have averted, or at least helped dampen the boom-bust cycle, is well accepted and shared among most economists and policy-makers. This explains the massive regulatory backlash from these crises.

This paper reviews some of the most infamous financial crisis in history and brings several patterns that are rarely discussed in the literature, at least not in a historical and crosssectional approach. It shows that in most cases regulation has been pro-cyclical, effectively weakening during the boom and strengthening during the bust. Regulators do not operate in a vacuum, and this paper shows how, in most cases, political interventions have helped fuel the boom in similar ways across time and countries. The political repercussions of crises, partly due to changes in the public's perception about the role of the government, are usually very significant. They help explain the reversal of policies and the regulatory backlash.

The interplay between politics and financial policy, described in this paper, has not received sufficient attention. The focus of the literature, which has been mostly cast in technical terms, is to find the optimal level of regulation that regulators should be enforcing. Will new regulations and their enforcement survive the test of time? History offers a relatively pessimistic answer to this question. It offers plenty of examples where regulatory failures can be attributed to political failures. Strengthened regulations and supervision are, in essence, tools given to regulators to use as long as the political climate allows them to. To what extent can regulators be insulated from changes in politicians' (and voters') philosophy toward regulation? What changes need to be made at the institutional level? This is an important question left for future research. Acknowledging the fact that politics can be the undoing of macro-prudential policy would be a step in the right direction.

\section{References}

Abiad, Abdul, and Ashoka Mody. "Financial reform: What shakes it? What shapes it?." American Economic Review 95, no. 1 (2005): 66-88.

Acharya, Viral V. "A theory of systemic risk and design of prudential bank regulation." Journal of financial stability 5, no. 3 (2009): 224-255. 
Acharya, Viral V., Menachem Brenner, Robert F. Engle, Anthony W. Lynch, and Matthew

Richardson. "Derivatives: the ultimate financial innovation." Restoring financial stability: How to repair a failed system 233 (2009): 241.

Acharya, Viral V., Thomas F. Cooley, Matthew P. Richardson, and Ingo Walter. Regulating Wall Street: The Dodd-Frank Act and the new architecture of global finance. Vol. 608. John Wiley Sons, 2010.

Acharya, Viral V., Thomas Cooley, Matthew Richardson, and Ingo Walter. "Manufacturing tail risk: A perspective on the financial crisis of 20072009." Foundations and Trends in Finance 4, no. 4 (2010): 247-325.

Acharya, Viral V., Thomas F. Cooley, Matthew P. Richardson, and Ingo Walter. "Market failures and regulatory failures: Lessons from past and present financial crises." (2011).

Acharya, Viral V., Thomas F. Cooley, Matthew P. Richardson, and Ingo Walter. "Market failures and regulatory failures: Lessons from past and present financial crises." (2011).

Acharya, Viral V., Matthew Richardson, Stijn Van Nieuwerburgh, and Lawrence J. White. Guaranteed to fail: Fannie Mae, Freddie Mac, and the debacle of mortgage finance. Princeton University Press, 2011.

Akin, Ozlem, Jos Garca Montalvo, Jaume Garca Villar, Jose-Luis Peydro, and Josep Maria Raya. "The real estate and credit bubble: evidence from Spain." SERIEs 5, no. 2-3 (2014): 223-243.

Alesina, A., and G. Tabellini, 2005. Why is Fiscal Policy Pro-Cyclical?. NBER Working Paper No. 11600, September 2005.

Allen, Roy E. The political economy of financial crises. Edward Elgar Publishing, 2004.

Allen, Franklin, and Douglas Gale. Understanding financial crises. OUP Oxford, 2009.

Alberdi, B., and Levenfeld, G., 1996. Housing Policy in Europe. London, Routledge.

Alma-Sabater, L., Conesa-Guillen, D., Forte-Deltell, A., Tortosa-Ausina, E., 2013. A Bayesian Perspective to Analyze Branch Location Patterns in Spanish Banking. Fundacion BBVA, Documentos de Trabajo 3, 2013.

Alston, Lee J., Wayne A. Grove, and David C. Wheelock. "Why do banks fail? Evidence from the 1920s." Explorations in Economic History 31, no. 4 (1994): 409-431. 
Amyx, Jennifer Ann. Japan's financial crisis: institutional rigidity and reluctant change. Princeton University Press, 2004.

Andersson, Fredrik and Jonung, Lars. "The credit and housing boom in Sweden, 1995-2015: Forewarned is forearmed." Vox (2016)

Andrews, Dan and Aida Caldera Snchez (2011), The Evolution of Homeownership Rates in Selected OECD Countries: Demographic and Public Policy Influences, OECD Journal: Economic Studies, Vol. 2011/1.

Andrews, Edmund L. "Greenspan concedes error on regulation." New York Times 23 (2008): B1.

Åsard, E. "Election Campaigns in Sweden and the United States: Convergence or Divergence?" American Studies in Scandinavia 21 (1989).

Baily, Martin Neil. "Distinguished Lecture on Economics in Government: The New Economy: Post Mortem or Second Wind?." The Journal of Economic Perspectives 16, no. 2 (2002): $3-22$.

Balino, T., Ubide, A., 1999. The Korean Crisis of 1997: A strategy of Financial Sector Reform. IMF Working Paper, WP/99/28.

Barnes, Victoria, and Lucy Newton. 2014. "The Apple Doesnt Fall Far from the Tree: English Bank Regulation and Branching Strategies in the Nineteenth Century." Center for International Business History(2014).

Barth, James R., Brumbaugh R. Dan, and Wilcox James A. "Policy Watch: The Repeal of Glass-Steagall and the Advent of Broad Banking." The Journal of Economic Perspectives 14, no. 2 (2000): 191-204.

Barth, J., Capiro, G., Levine, R., 2012. Guardians of Finance: Making Regulators Work For Us. MIT Press.

Barth, James. The rise and fall of the US mortgage and credit markets: A comprehensive analysis of the market meltdown. John Wiley Sons, 2009

Becker, Jo, Sheryl Gay Stolberg, and Stephen Labaton. "Bush drive for home ownership fueled housing bubble." New York Times: Business (2008).

Belsky, E., and N. Retsinas. "History of housing finance and policy in Spain." Cambridge MA: Harvard University (working paper) (2004). 
Beltratti, Andrea, and Ren M. Stulz. Why did some banks perform better during the credit crisis? A cross-country study of the impact of governance and regulation. No. w15180. National Bureau of Economic Research, 2009.

Becker, G., 1983. A Theory of Competition among Pressure Groups for Political Influence. Quarterly Journal of Economics, 98, 371-400.

Benmelech, Efraim, and Tobias J. Moskowitz. "The political economy of financial regulation: evidence from US state usury laws in the 19th century." The journal of finance 65, no. 3 (2010): 1029-1073.

Bekaert, Geert, Campbell R. Harvey, and Christian Lundblad. Growth volatility and financial liberalization. Journal of International Money and Finance 25, 3 (2006): 370-403.

Bernanke, Ben S. Non-monetary effects of the financial crisis in the propagation of the Great Depression. No. w1054. National Bureau of Economic Research, 1983.

Bernanke, Ben S. The macroeconomics of the Great Depression: A comparative approach. No. w4814. National Bureau of Economic Research, 1994.

Bernstein, Michael A. The Great Depression: delayed recovery and economic change in America, 1929-1939. Cambridge University Press, 1989.

Blanchard, Olivier, Giovanni DellAriccia, and Paolo Mauro. "Rethinking macroeconomic policy." Journal of Money, Credit and Banking 42, no. s1 (2010): 199-215.

Blechinger, Verena. "Corruption through political contributions in Japan." Transparency International Workshop on Corruption And Political Party Funding, La Pietra, Italy. 2000.

Blinder, Alan. "Six errors on the path to the financial crisis." The New York Times, January 24 (2009).

Blinder, Alan S. After the music stopped: The financial crisis, the response, and the work ahead. Penguin Books, 2013.

Blinder, Alan S. "Financial Entropy and the Optimality of Over-regulation." The New International Financial System: Analyzing the Cumulative Impact of Regulatory Reform 48 (2015): 3 .

Bowman, K., O'Neil, E., and H. Sims, 2015. "Dodd-Frank at Five: Public Opinion on Wall Street, Banks, and Financial Regulation." American Enterprise Institution, AEI Special Poll Report, 2015. 
Browne, Eric C., and Sunwoong Kim. "Japan: Prosperity, dominant party system, and delayed liberalization." The Political Economy of International Financial Crises: Interest Groups, Ideologies, and Institutions, edited by S. Horowitz and U. Heo. Lanham, Md.: Rowman and Littlefield (2001): 133-149.

Calomiris, Charles W., and Stephen H. Haber. "Fragile by design." The political origin of banking crises and scarse credit. The Princeton Economic History of the Western World, Joel Mokyr, Series Editor (2014).

Calomiris, Charles W. "The political lessons of Depression-era banking reform." Oxford Review of Economic Policy 26, no. 3 (2010): 540-560.

Cameron, Rondo E. Banking in the early stages of industrialization: a study in comparative economic history. New York: Oxford University Press, 1967.

Caprio, Gerard, and Daniela Klingebiel. "Bank insolvency: bad luck, bad policy, or bad banking?" In Annual World Bank conference on development economics, vol. 79. 1996.

Crdenas, Amalia. "The Spanish Savings Bank Crisis: History, Causes and Responses." IN3 Working Paper Series (2013).

Carswell, John. The South Sea Bubble. Dover: Alan Sutton, 1993.

Chancellor, Edward. Devil take the hindmost: A history of financial speculation. New York, NY, USA:: Plume, 2000.

Christiano, Lawrence J., Roberto Motto, and Massimo Rostagno. The great depression and the Friedman-Schwartz hypothesis. No. w10255. National Bureau of Economic Research, 2004.

Chandler, Alfred D., Jr., The VisibleH and: The Managerial Revolution in American Business. Cambridge: Harvard University Press, 1977

Chancellor, Edward, 1999. Devil Takes the Hindmost: A History of Financial Speculation.

Cihak, Martin, Asli Demirguc-Kunt, Maria Soledad Martinez Peria, and Amin MohseniCheraghlou. "Bank regulation and supervision around the world: a crisis update." (2012).

Chwieroth, Jeffrey. "The crisis in global finance: political economy perspectives on international financial regulatory change." (2011). 
Claessens, Stijn, Mr Luc Laeven, Deniz Igan, and Mr Giovanni Dell'Ariccia. Lessons and policy implications from the global financial crisis. No. 10-44. International Monetary Fund, 2010.

Coates, John C. "The goals and promise of the Sarbanes-Oxley Act." The Journal of Economic Perspectives 21, no. 1 (2007): 91-116.

Cole, David, and Betty F. Slade. Building a modern financial system: The Indonesian experience. Cambridge University Press, 1998.

Cole, H.L. and Ohanian, L.E., 2004. New Deal policies and the persistence of the Great Depression: A general equilibrium analysis. Journal of Political Economy, 112(4), pp.779816.

Coffee Jr, John C. "Understanding Enron:" It's About the Gatekeepers, Stupid"." The Business Lawyer (2002): 1403-1420.

Calomiris, Charles W. "Financial factors in the Great Depression." The Journal of Economic Perspectives (1993): 61-85.

Calomiris, Charles W., and Joseph R. Mason. "Consequences of bank distress during the Great Depression." American Economic Review (2003): 937-947.

Claessens, Stijn, and Ms Laura E. Kodres. The regulatory responses to the global financial crisis: some uncomfortable questions. No. 14-46. International Monetary Fund, 2014.

Congleton, Roger D. "On the political economy of the financial crisis and bailout of 20082009." Public Choice 140, no. 3-4 (2009): 287-317.

Connor, Gregory, Thomas Flavin, and Brian OKelly. "The US and Irish credit crises: Their distinctive differences and common features." Journal of International Money and Finance 31, no. 1 (2012): 60-79.

Cuat, Vicente, and Luis Garicano. 2010. "Did good cajas extend bad loans? governance, human capital and loan portfolios." Working Paper, Fundacion de Estudios de Economia Applicada, 2010-08.

Cihak, M., Demirguc-Kunt, A., Martinez Peria, M.S., Mohseni-Cheraghlou, A., 2012. Bank regulation and supervision around the world: a crisis update, World Bank Policy Research Working Paper 6286, December 2012. 
Dagher, Jihad C., Giovanni Dell'Ariccia, Luc Laeven, Lev Ratnovski, and Hui Tong. "Benefits and costs of bank capital." (2016).

Dell'Ariccia, Giovanni, Deniz Igan, and Luc Laeven. "Credit booms and lending standards: Evidence from the subprime mortgage market." (2008).

Dellepiane,Sebastian, Niamh Hardiman, and Jon Las Heras. "Building on Easy Money: The Political Economy of Housing Bubbles in Ireland and Spain." In APSA 2013 Annual Meeting Paper. 2013.

Demirg-Kunt, Asli, and Enrica Detragiache. Financial liberalization and financial fragility. No. 1917. World Bank Publications, 1998.

Dewatripont, Mathias, Jean-Charles Rochet, and Jean Tirole. Balancing the banks: Global lessons from the financial crisis. Princeton University Press, 2010.

Demyanyk, Yuliya, and Otto Van Hemert. "Understanding the subprime mortgage crisis." The Review of Financial Studies 24, no. 6 (2009): 1848-1880.

Dickson, Peter George Muir. The Financial Revolution in England: a study in the development of public credit, 1688-1756. Macmillan, 1967.

Dimitrov, Valentin, Darius Palia, and Leo Tang. "Impact of the Dodd-Frank act on credit ratings." Journal of Financial Economics 115, no. 3 (2015): 505-520.

Eichengreen, Barry. Golden fetters: the gold standard and the Great Depression, 1919-1939. Oxford University Press, 1992.

Engel, Ellen, Rachel M. Hayes, and Xue Wang. "The SarbanesOxley Act and firms goingprivate decisions." Journal of Accounting and Economics 44, no. 1 (2007): 116-145.

microtype

European Parliament (2007) Report on the Fact Finding Visit to Madrid, Valencia, Andalucia.

Faiola, Anthony, Ellen Nakashima, and Jill Drew. "What went wrong." Washington Post 15 (2008): 15 .

Fama, Eugene F., and Robert Litterman. "An experienced view on markets and investing." Financial Analysts Journal 68, no. 6 (2012): 15-19. 
Financial Crisis Inquiry Commission, and United States. Financial Crisis Inquiry Commission. The financial crisis inquiry report: Final report of the national commission on the causes of the financial and economic crisis in the United States. Public Affairs, 2011.

Financial Executive International (FEI), 2005. Section 404 Costs Survey /http://www.fei.org/404 urvey $_{32} 1_{0} 5$.cfmS

Financial Times, 2015. Two-party system latest victim of Spains financial crisis, by Tobias Buck. June 25, 2015. http://www.ft.com/intl/cms/s/0/aeb06e3c-0096-11e5-a90800144feabdc0.htmlaxzz45ipm2NGr

Fisher, Irving, "The Debt-Deflation Theory of Great Depressions," Econometrica, October 1933, 1, 337-57.

Friedman, Milton, and Anna J. Schwartz, A Monetary History of the United States, 18671960. Princeton: Princeton University Press, 1963.

Friedman, Jeffrey. "A crisis of politics, not economics: Complexity, ignorance, and policy failure." Critical Review 21, no. 2-3 (2009): 127-183.

Federal Reserve Bank of St. Louis. Dual Banking System in the United States. 1932

Fernandez-Villaverde, Jesus, Luis Garicano, and Tano Santos. "Political credit cycles: The case of the euro zone." Journal of Economic Perspectives 27-3 (2013): 145166.

Frankel, A., and P. Morgan. 1992. Deregulation and Competition in Japanese Banking. Federal Reserve Bank of St. Louis. Federal Reserve Bulletin, August.

Fujii, Mariko, and Masahiro Kawai. "Lessons from Japans banking crisis, 1991-2005." (2010).

Funke, Manuel, Moritz Schularick, and Christoph Trebesch. "Going to extremes: Politics after financial crises, 18702014." European Economic Review 88 (2016): 227-260.

Galbraith, John Kenneth, The Great Crash 1929. Boston: Houghton Mifflin Company, 1954 and 1988.

Garber, Peter M. (1990), "Famous First Bubbles", The Journal of Economic Perspectives, The Journal of Economic Perspectives, Vol. 4, No. 2, 4 (2): 3554

Gerding, Erik, 2006. The Next Epidemic: Bubbles and the Growth and Decay of Securities Regulation. Connecticut Law Review, Vol 38:393. 
Gerardi, Kristopher, Andreas Lehnert, Shane M. Sherlund, and Paul Willen. "Making sense of the subprime crisis." Brookings Papers on Economic Activity 2008, no. 2 (2008): 69-159.

Glick, Reuven, and Michael Hutchison. "Capital controls and exchange rate instability in developing economies." Journal of International Money and Finance 24, no. 3 (2005): 387412.

Gonzalez, Libertad, and Francesc Ortega. "Immigration and housing booms: Evidence from spain*." Journal of Regional Science 53, no. 1 (2013): 37-59.

Gordon, Jeffrey N. "Governance failures of the Enron board and the new information order of Sarbanes-Oxley." Conn. L. Rev. 35 (2002): 1125.

Gorton, G. (1988). Banking Panics and Business Cycles, Oxford Economic Papers 40, 751781.

Gorton, Gary, and Andrew Metrick. "Regulating the shadow banking system." Brookings Papers on Economic Activity 2010, no. 2 (2010): 261-297.

Gorton, Gary B. Slapped by the invisible hand: The panic of 2007. Oxford University Press, 2010.

Gorton, Gary. 2012. Misunderstanding financial crises: Why we don't see them coming. Oxford University Press, 2012.

Greenberger, Michael. "The role of derivatives in the financial crisis." Testimony before the Financial Crisis Inquiry Commission (2010).

Greenspan, A. and Waxman, M., 2008, October. The Financial Crisis and the role of federal regulators. In Testimony before US Congress. House Committee on Oversight and Government Reform. 110th Cong., 2nd sess (Vol. 23).

Grigsby, William G. "Housing finance and subsidies in the United States." Urban Studies 27 , no. 6 (1990): 831-845.

Grigsby, William G., and Steven C. Bourassa. "Trying to understand low-income housing subsidies: lessons from the United States." Urban Studies 40, no. 5-6 (2003): 973-992.

Grimes, William W. "The Political Economy of the Japanese Financial Big Bang: Institutional Change in Finance and Public Policymaking (review)." The Journal of Japanese Studies 34, no. 1 (2008): 149-153. 
Gulati, M., Rachlinski, J., Langevoort, D., 2005. Fraud by Hindsight. Cornell Law Faculty Publications.

Haggard, Stephan. The political economy of the Asian financial crisis. Peterson Institute, 2000.

Harris, Ron. "The Bubble Act: Its passage and its effects on business organization." The Journal of Economic History 54, no. 03 (1994): 610-627.

Heckinger, Richard, David Mengle, Robert Steigerwald, Ivana Ruffini, and Kirstin Wells. "Understanding Derivatives: Markets and Infrastructure." Federal Reserve Bank of Chicago (2013).

Henry, Peter Blair. "Do stock market liberalizations cause investment booms?." Journal of Financial economics 58, no. 1 (2000): 301-334.

Horowitz, Shale Asher, and Uk Heo. The political economy of international financial crisis: interest groups, ideologies, and institutions. Rowman Littlefield, 2001.

Philip T. Hoffman, Gilles Postel-Vinay and Jean-Laurent Rosenthal, Surviving Large Losses: Financial Crises, the Middle Class, and the Development of Financial Markets. Cambridge, MA: Harvard University Press, 2007. viii + 263 pp. 28(hardcover), ISBN : $978-0-674-$ $02469-4$.

Igan, Deniz, Prachi Mishra, and Thierry Tressel. "A fistful of dollars: lobbying and the financial crisis." NBER Macroeconomics Annual 26, no. 1 (2012): 195-230.

Igan, Deniz, and Prachi Mishra. "Wall street, capitol hill, and K street: Political influence and financial regulation." Journal of Law and Economics 57, no. 4 (2014): 1063-1084.

Illueca, Manuel, Lars Norden, and Gregory F. Udell (2008) Liberalization, Corporate Governance, and Savings banks. In EFA 2008 Athens Meetings Paper. 2008.

Fernandez-Villaverde, J., Garicano, L., Santos, T, 2013. Political Credit Cycles: the case of the Eurozone. Mimeo

Groll, Thomas and O'Halloran, Sharyn and McAllister, Geraldine, Delegation and the Regulation of Financial Markets (December 15, 2015).

Hall, Maximilian JB. "Financial Reform in Japan: Causes and Consequences" Edward Elgar Pub (February 1999). 
Hall, Maximilian JB. "Recent banking reforms in Japan: an assessment." (2004).

Hamilton, James D., "Monetary Factors in the Great Depression," Journal of Monetary Economics, 1987, 19, 145-169.

Hammond, Bray. Banks and Politics in America from the Revolution to the Civil War. Princeton University Press, 1957.

Higgs, R., 1989. Crisis and Leviathan: Critical episodes in the growth of American government. Oxford University Press, USA.

Hotta, Kenusuke, 1992, "Deregulation of the Japanese Financial Markets and the Role of Japanese Banks," Occasional Paper series No 7, Center on Japanese Economy and Business, Columbia University.

Honohan, P. (2010). The Irish banking crisis, regulatory and financial stability policy 20032008. A report to the Minister of Finance. Dublin: The Stationery Office.

Horowitz, Shale Asher, and Uk Heo, eds. The political economy of international financial crisis: interest groups, ideologies, and institutions. Rowman Littlefield, 2001.

Horton, D.C., Larsen, H.C., Wall, N.J., 1942. Farm mortgage credit facilities in the US. US Department of Agriculture, Pub 478.

Hoshi, Takeo, and Anil Kashyap. "The Japanese Banking Crisis: Where did it come from and how will it end?." In NBER Macroeconomics Annual 1999, Volume 14, pp. 129-212. MIT, 2000.

Hoshi, Takeo, Anil Kashyap, and David Scharfstein. The choice between public and private debt: An analysis of post-deregulation corporate financing in Japan. No. w4421. National Bureau of Economic Research, 1993.

Hoshi, Takeo, and Anil K. Kashyap. "Japan's financial crisis and economic stagnation." The Journal of Economic Perspectives 18, no. 1 (2004): 3-26.

Hutchison, Michael, and Kathleen McDill. "Are all banking crises alike? The Japanese experience in international comparison." Journal of the Japanese and International Economies 13, no. 3 (1999): 155-180.

Igan, Deniz, Prachi Mishra, and Thierry Tressel. A fistful of dollars: lobbying and the financial crisis. No. w17076. National Bureau of Economic Research, 2011. 
Illueca, Manuel, Lars Norden, and Gregory F. Udell. "Liberalization, corporate governance, and savings banks." In EFA 2008 Athens Meetings Paper. 2008.

IMF (2012). Safety Net, Bank Resolution, and Crisis Management Framework. Financial Sector Assessment Program Update: Spain, technical note. May 2012.

IMF (2006). Offshore Financial Centers The Assessment Program A Progress Report. https://www.imf.org/external/np/pp/eng/2006/020806.pdf

IMF (2014a). Ireland: Detailed Assessment of Observance of Basel COre Principles for Effective Banking Supervision. IMF Country Report No. 14/135.

IMF (2014b). Spain: Financial Sector ReformFinal Progress Report. IMF Country Report No. $14 / 59$.

Iwamoto, Yoshiyuki. Japan on the Upswing: Why the Bubble Burst and Japan's Economic Renewal. Algora Publishing, 2006.

Jacob, Charles, E. "Reagonomics:The Revolution in the American Political Economy." Law and Contemporary Problems, Vol. 48, No. 4 (1985):pp. 7-30.

Jackson, Jame, 2009. The Financial Crisis: Impact on and Response by The European Union. Congressional Research Service.

Jermann, Urban J., and Vincenzo Quadrini. "Stock market boom and the productivity gains of the 1990s." Journal of Monetary Economics 54, no. 2 (2007): 413-432.

Jiménez, Fernando. "Building boom and political corruption in Spain." South European Society and Politics 14, no. 3 (2009): 255-272.

Jiménez, Fernando, and Manuel Villoria. "Political finance, urban development and political corruption in Spain." Money, corruption, and political competition in established and emerging democracies (2012): 121-144.

Kaminsky, G. L., Reinhart, C. M. (1999). The twin crises: the causes of banking and balance-of-payments problems. American economic review, 473-500.

Kose, M. Ayhan, Prasad, Eswar, Rogoff, Kenneth, and Wei, Shang-Jin.(2006) "Financial Globalization, A Reappraisal." IMF Working Paper 06/189.

Komai, Alejandro, and Gary Richardson. A brief history of regulations regarding financial markets in the United States: 1789 to 2009. No. w17443. National Bureau of Economic Research, 2011. 
Kane, Edward J. "Missing elements in US financial reform: A Kbler-Ross interpretation of the inadequacy of the Dodd-Frank Act." Journal of Banking Finance 36, no. 3 (2012): 654-661.

Graciela Laura Kaminsky Sergio L. Schmukler, 2008. "Short-Run Pain, Long-Run Gain: Financial Liberalization and Stock Market Cycles," Review of Finance, Oxford University Press for European Finance Association, vol. 12(2), pages 253-292.

Kelly, Morgan. "The Irish Credit Bubble." UCD Center for Economic Research Working Paper 09/32 (2009)

Kroszner, Randall S. "On the political economy of banking and financial regulatory reform in emerging markets." CRSP Working Paper no. 472 (1998).

Kroszner, Randall S., Robert J. Shiller, and Benjamin M. Friedman. Reforming US Financial Markets: Reflections Before and Beyond Dodd-Frank. MIT Press, 2011.

Karaki, Akiko. "Regulation and Compliance in Japanese Financial Institutions." Colum. J. Asian L. 14 (2000): 327.

Kindleberger, C.P and R. Aliber, 2001. Manias, panics, and crashes. Palgrave Macmillan, 2001.

Labaton, Stephen. "SEC concedes oversight flaws fueled collapse." New York Times 26 (2008): 2008.

Lam, Alven. "Government Interventions in Housing Finance MarketsAn International Overview." (2011).

Levine, Ross. "The governance of financial regulation: reform lessons from the recent crisis." International Review of Finance 12, no. 1 (2012): 39-56.

Lo, Andrew W. "Forthcoming.Reading About the Financial Crisis: A 21-Book Review.." Journal of Economic Literature.

Libecap, G.D., 1997. The Great Depression and the Regulating State: Federal Government Regulation of Agriculture: 1884-1970 (No. w5986). National Bureau of Economic Research.

Lipscy, Phillip Y., and Hirofumi Takinami. "The Politics of Financial Crisis Response in Japan and the United States." Japanese Journal of Political Science 14, no. 03 (2013): 321353. 
Mrquez, Antonio Montiel and Naredo, Jos Manuel. 2011. El modelo inmobiliario espaol y su culminacin en el caso valenciano. Barcelona, Icario Antrazyt. 2011.

Mackay, Charles. Memoirs of extraordinary popular delusions and the madness of crowds. George Routledge and Sons, 1869.

Martn-Acea, Pablo, Angeles Pons, and Concepcin Betrn. "Financial Crises and Financial Reforms in SpainWhat Have We Learned?." In Financial Market Regulation in the Wake of Financial Crises: The Historical Experience Conference, p. 119. 2009.

McCrone, G., and Stephens, M., 1996. Housing Policy in Britain and Europe. London, UCL Press.

McKinnon, Ronald I. The order of economic liberalization: Financial control in the transition to a market economy. JHU Press, 1993.

McCarty, Nolan, Keith T. Poole, and Howard Rosenthal. Political Bubbles: Financial Crises and the Failure of American Democracy. Princeton University Press, 2013.

Menelaos, G., and Norris, M. (2011). "If you build it, they will come: governing property-led rural regeneration in Ireland." Land Use Policy, 28, 447-638.

Mian, Atif, Amir Sufi, and Francesco Trebbi. The political economy of the subprime mortgage credit expansion. No. w16107. National Bureau of Economic Research, 2010.

Mian,, Sufi, and Trebbi. The Political Economy of the Subprime Mortgage Credit Expansion. Quarterly Journal of Political Science 2013.8 (2013): , 2013, 8, 373-408. Print.

Mian, Atif, Amir Sufi, and Francesco Trebbi. The political economy of the US mortgage default crisis. No. w14468. National Bureau of Economic Research, 2008.

Mian, Atif, Amir Sufi, and Francesco Trebbia. "The political economy of the US mortgage default crisis." The American economic review 100, no. 5 (2010): 1967-1998.

Mian, Atif, Amir Sufi, and Francesco Trebbi. "Resolving debt overhang: political constraints in the aftermath of financial crises." American Economic Journal: Macroeconomics 6, no. 2 (2014): 1-28.

Mian, Atif, and Amir Sufi. House of debt: How they (and you) caused the Great Recession, and how we can prevent it from happening again. University of Chicago Press, 2015.

Mikitani, Ryichi, and Adam Simon Posen, eds. Japan's financial crisis and its parallels to US experience. Vol. 13. Peterson Institute, 2000. 
Minsky, Hyman P. "The financial instability hypothesis." The Jerome Levy Economics Institute Working Paper 74 (1992).

Mishkin, Frederic S. Asymmetric information and financial crises: a historical perspective. No. w3400. National Bureau of Economic Research, 1990.

Newton, Lucy, and Philip L. Cottrell. "Joint-stock banking in the English provinces 18261857: To branch or not to branch?." Business and Economic History 27, no. 1 (1998): $115-128$.

Okina, Kunio, Masaaki Shirakawa, and Shigenori Shiratsuka. "The asset price bubble and monetary policy: Japans experience in the late 1980s and the lessons." Monetary and Economic Studies (Special Edition) 19, no. 2 (2001): 395-450.

Park, Y.C., 1998. The Financial Crisis in Korea and Its Lessons for Reform ofthe International Financial System. Regulatory and Supervisory Challenges in a New Era of Global Finance, The Hague, 1998,

Patel, Dharmesh Ramesh. "The Political economy of financial crisis." Available at SSRN 2263330 (2013).

Patterson, Margaret, and David Reiffen. "The Effect of the Bubble Act on the Market for Joint Stock Shares." The Journal of Economic History 50, no. 01 (1990): 163-171.

Patrick, Hugh T. "The causes of Japan's financial crisis." (1998).

Peek, Joe, and Eric S. Rosengren. Unnatural selection: Perverse incentives and the misallocation of credit in Japan. No. w9643. National Bureau of Economic Research, 2003.

Prez, Sofa A. Banking on Privilege: The Politics of Spanish Financial Reform. Ithaca: Cornell University Press, 1997.

Puri, Manju. 1996. "Commercial Banks in In- vestment Banking: Conflict of Interest or Certi- fication Role?" Journal of Financial Economics. 40, pp. 373-401.

O Keeffe, M. and Terzi, A. The Political Economy of Financial Crisis Policy. Bruegel Working Paper, July 2015

Okazaki, Tetsuji and Michiru Sawada (2006). Effects of a Bank Consolidation Promotion Policy: Evaluating Bank Law in 1927 Japan. CIRJE Discussion Paper F-400 (February).

Kataoka, H., 1999. Korean Banking Reform Following the Asian Financial Crisis. Columbia Business school, Discussion paper No. 10. 
Kaufman, George G., and Larry R. Mote. "Glass-Steagall: Repeal by regulatory and judicial reinterpretation." Banking LJ 107 (1990): 388.

Kawai, Masahiro. "Reform of the Japanese banking system." International Economics and Economic Policy 2, no. 4 (2005): 307-335.

Keynes, John M., "The Consequences to the Banks of the Collapse of Money Values," (1931). In Essays in Persuasion. New York: W. W. Norton and Company, [1963].

Kihwan, K., 2006. The 1997-98 Korean Financial Crisis: Causes, Policy Response, and Lessons. Seminar on Crisis Prevention in Emerging Markets.

Kindleberger, C., 1989, Manias, Panics, and Crashes: A History of Financial Crises, New York: Basic Books.

Kroszner, Randall and Ragu Rajan. 1997. "Or- ganization Structure and Credibility: Evidence from Commercial Bank Securities Activities be- fore the Glass-Steagall Act." Journal of Monetaty Economics. 39:3, pp. 475-516.

Kroszner, R., Strahan, P., 1999. What Drives Deregulation? Economics and Politics of the Relaxation of Bank Branching Restriction. Quarterly Joural of Economics, pp. 1437 - 1467.

Krueger, A.O., Yoo, J., 2002. Chaebol Capitalism and the Currency-Financial Crisis in Korea. Preventing Currency Crises in Emerging Markets. University of Chicago Press.

Krugman, P., 1998. What happened to Asia? Cambridge: Massachusetts Institute of Technology, January. Unpublished manuscript.

Laffont, J.J., Tirole, J., 1993. A Theory of Incentives in Regulation and Procurement.

Lam, Alvin. 2011. Government Interventions in Housing Finance Markets: An International Overview. Working Paper. U.S. Department of Housing and Urban Development.

Milhaupt, Curtis J., and Geoffrey P. Miller. "Cooperation, conflict, and convergence in japanese finance: evidence from the Jusen problem." Law Pol'y Int'l Bus. 29 (1997): 1.

Mitchener, Kris James, and Mari Ohnuki. "Institutions, competition, and capital market integration in Japan." The Journal of Economic History 69, no. 01 (2009): 138-171.

Neal, Larry. The rise of financial capitalism: International capital markets in the age of reason. Studies in Monetary and Financial History, Cambridge: Cambridge University Press, 1990. 
Neal, Larry. "The financial crisis of 1825 and the restructuring of the British financial system." Federal Reserve Bank of St Louis, Review 80 (1998).

Niskanen, William A. Reaganomics: An insider's account of the policies and the people. Oxford University Press, USA, 1988.

Norris, Michelle, and Dermot Coates. "How housing killed the Celtic tiger: Anatomy and consequences of Irelands housing boom and bust." Journal of Housing and the Built Environment 29, no. 2 (2014): 299-315.

Ofek, Eli, and Matthew Richardson. "DotCom mania: the rise and fall of Internet stock prices." Journal of Finance (2000): 58-3.

Obstfeld, Maurice, and Alan M. Taylor. The great depression as a watershed: international capital mobility over the long run. No. w5960. National Bureau of Economic Research, 1997.

Obstfeld, Maurice, and Kenneth Rogoff. "Global imbalances and the financial crisis: products of common causes." CEPR Discussion Paper No. DP7606 (2009).

Ohanian, Lee E. "Whator whostarted the great depression?." Journal of Economic Theory 144, no. 6 (2009): 2310-2335. Harvard

O'Toole, Fintan. Ship of Fools: How stupidity and corruption sank the Celtic Tiger. Faber Faber, 2009.

Pstor, ubo, and Pietro Veronesi. "Was there a Nasdaq bubble in the late 1990s?." Journal of Financial Economics 81, no. 1 (2006): 61-100.

Peach, W. Nelson, The Security Affiliates of National Banks, Baltimore: Johns Hopkins Press, 1941.

Peltzman, S., 1976. Toward a More General Theory of Regulation. Journal of Law and Economics, 10, 109-148.

Peltzman, S., 1989. The Economic Theory of Regulation after a Decade of Deregulation, Brookings papers: Microeconomics, 1-41.

Perez, Carlota. "The double bubble at the turn of the century: technological roots and structural implications." Cambridge Journal of Economics 33, no. 4 (2009): 779-805.

Posner, Eric A. "The political economy of the Bankruptcy Reform Act of 1978." Michigan Law Review 96, no. 1 (1997): 47-126. 
Persson, T., Tabellini, G., 2000. Political Economics: explaining Economic Policy (Cambridge, MA: MIT Press).

Radelet, S., Sachs, J., 2000. The Onset of the East Asian Financial Crisis. Currency Crises pp. 105 - 153. University of Chicago Press.

Rajan, Raghuram G. Fault lines: How hidden fractures still threaten the world economy. Princeton University Press, 2011.

Rajan, Raghuram G., and Rodney Ramcharan. Constituencies and legislation: The fight over the mcfadden act of 1927. No. w17266. National Bureau of Economic Research, 2011.

Reinhart, Carmen M., and Kenneth Rogoff. This time is different: eight centuries of financial folly. princeton university press, 2009.

Reiss, David J. "Subprime standardization: How rating agencies allow predatory lending to flourish in the secondary mortgage market." Florida State University Law Review, Vol. 33, (2006).

Ribstein, Larry E. "Market vs. regulatory responses to corporate fraud: A critique of the Sarbanes-Oxley Act of 2002." J. Corp. L. 28 (2002): 1.

Roberts, Russell. "How government stoked the mania." Wall Street Journal 3 (2008): A21.

Roberts, Robin W., Peggy D. Dwyer, and John T. Sweeney. "Political strategies used by the US public accounting profession during auditor liability reform: The case of the Private Securities Litigation Reform Act of 1995." Journal of Accounting and Public Policy 22, no. 5 (2003): 433-457.

Robles-Egea, Antonio, and Santiago Delgado-Fernández. "Corruption in Democratic Spain. Causes, Cases and Consequences." In ECPR General Conference, Glasgow. 2014.

Rogoff, Kenneth (1990) Equilibrium Political Budget Cycles American Economic Review, 80: $21-36$.

Romano, R., 2005. The SarbanesOxley Act and the making of quack corporate governance. Yale Law Journal 114, 15211561.

Romer, C.D., 1988. The great crash and the onset of the great depression (No. w2639). National Bureau of Economic Research.

Romer, Christina D. "What ended the great depression?." The Journal of Economic History 52, no. 04 (1992): 757-784. 
Rosenbluth, Frances, and Michael F. Thies. "The Electoral Foundations of Japan's Banking Regulation." Policy Studies Journal 29, no. 1 (2001): 23-37.

Ross, Edward A. "Sinking Funds." Publications of the American Economic Association 7, no. 4/5 (1892): 9-106.

Rowe III, Robert G., and Kenneth A. Guenther. "Erosion of the Glass-Steagall Act and the Bank Holding Company Act, The.” Banking LJ 115 (1998): 663.

Rypkema, Donovan D. Historic preservation and affordable housing: The missed connection. Washington, DC: National Trust for Historic Preservation, 2002.

Sanders, Karen B., Rosa Berganza, and Roberto de Miguel. "Populism from the far right to the emergence of Podemos." Populist political communication in Europe. London: Routledge (2016): 249-260.

Santos, Tano, 2012. "The Eurozone crisis, chapter 4: Spain." Presentation, Columbia Business School.

Santos, Tano, 2014. Antes del diluvio: The Spanish banking system in the first decade of the euro. Working Paper, Columbia Business School.

Saurina, Jesus, 2009. Dynamic Provisioning: The Experience of Spain. The World Bank, Crisis Response, July 2009, Number 7.

Schaede, Ulrike. "The 1995 financial crisis in Japan." Berkeley Roundtable on the International Economy (1996).

Schwartz, Herman, and Leonard Seabrooke. The Politics of Housing Booms and Busts. Springer, 2009.

Securities and Exchange Commission. 2008. Chairman Cox Announces End of Consolidated Supervised Entities Program. Washington, D.C., Sept. 26, 2008. http://www.sec.gov/news/press/2008/2008-230.htm

Sherman, Matthew. "A Short History of Financial Deregulation in the United States." Center for Economic and Policy Research (2009).

Shiller, Robert J. The subprime solution: how today's global financial crisis happened, and what to do about it. Princeton University Press, 2012. 
Shizume, Masato. "The Japanese economy during the interwar period: instability in the financial system and the impact of the world depression." In The Gold Standard Peripheries, pp. 211-228. Palgrave Macmillan UK, 2012.

Shizume, Masato, and Masayoshi Tsurumi. Modernizing the financial system in Japan during the 19th century: National Banks in Japan in the Context of Free Banking. No. E16075. WINPEC Working Paper, 2016.

Seligman, Joel. Rethinking Private Securities Litigation, 73 U. Cin. L. Rev. 95, 138 (2004)

Sirri, Erik, 2009. "Remarks at the National Economists Club: Securities Markets and Regulatory Reform." Speech by SEC Staff (2009). Washington DC.

Solomon, D., Brian-Low, C., 2004. Companies complain about cost of corporate-governance rules. Wall Street Journal (February 10).

Snowden, Kenneth A. The anatomy of a residential mortgage crisis: A look back to the 1930s. No. w16244. National Bureau of Economic Research, 2010.

Shiller, R. J. (2000). Irrational Exuberance. Princeton University Press, Princeton, New Jersey

Schularick, Moritz, and Alan M. Taylor. Credit booms gone bust: Monetary policy, leverage cycles and financial crises, 1870-2008. No. w15512. National Bureau of Economic Research, 2009.

Schultz, Paul H. Perspectives on Dodd-Frank and Finance. MIT Press, 2014.

Stigler, G., 1971. The Theory of Economic Regulation. The Bell Journal of Economics and Management Science, 2(1), 3-21.

Stiglitz, Joseph E. "Rethinking macroeconomics: What failed, and how to repair it." Journal of the European Economic Association 9, no. 4 (2011): 591-645.

Stout, Lynn A. "Derivatives and the legal origin of the 2008 credit crisis." Harvard Business Law Review 1 (2011): 1-38.

Sol-Oll,A., Viladecans-Marsal, E., 2012, Lobbying, political competition, and local land supply: Recent evidence from Spain, Journal of Public Economics, Volume 96, Issues 12, February 2012, Pages 10-19,

Talvi, Ernesto, and Carlos A. Vegh. "Tax base variability and procyclical fiscal policy in developing countries." Journal of Development economics 78, no. 1 (2005): 156-190. 
Temin, Peter and Voth, Hans-Joachim . Riding the South Sea Bubble. American Economic Review, 94(5): 1654-1668.

Torreblanca, José Ignacio. Asaltar los cielos: podemos o la poltica después de la crisis. Debate, 2015.

Tornell, Aaron and Philip Lane (1999) Voracity and Growth American Economic Review, 89: $22-46$.

Tornell, A. and Westermann, F. (2005) Boom-Bust Cycles and Financial Liberalization. Cambridge, MA: MIT Press.

Ueda, Kazuo. "Causes of Japans Banking Problems in the 1990s." Crisis and Change in the Japanese Financial System (2000): 59-81.

Vickers, Raymond B. Panic in paradise: Florida's banking crash of 1926. Vol. 45879. University of Alabama Press, 1994.

Villoria, Manuel, Gregg G. Van Ryzin, and Cecilia F. Lavena. "Social and political consequences of administrative corruption: A study of public perceptions in Spain." Public Administration Review 73, no. 1 (2013): 85-94.

Wallison, Petter J. "Government housing policy and the financial crisis." Cato J. 30 (2010): 397.

Western, David L. Booms, Bubbles and Busts in US Stock Markets. Routledge, 2004.

White, Eugene Nelson. "The political economy of banking regulation, 18641933." The Journal of Economic History 42, no. 01 (1982): 33-40.

White, Eugene Nelson. "Before the Glass-Steagall Act: An analysis of the investment banking activities of national banks." Explorations in Economic History 23, no. 1 (1986): 33-55.

White, Eugene N.. 1990. The Stock Market Boom and Crash of 1929 Revisited. The Journal of Economic Perspectives 4 (2). American Economic Association: 6783.

White, Lawrence J. "The CreditRating Agencies and the Subprime Debacle." Critical Review 21, no. 2-3 (2009): 389-399.

Wilmarth, Arthur E. "Does Financial Liberalization Increase the Likelihood of a Systemic Banking Crisis." in Too big to fail: policies and practices in government bailouts. Greenwood Publishing Group, 2004. 
Wilmarth Jr, Arthur E. "Dodd-Frank Act: A Flawed and Inadequate Response to the TooBig-to-Fail Problem, The." Or. L. Rev. 89 (2010): 951.

Willis, Henry Parker, John Martin Chapman, John G. Becker, and Jules Irwin Bogen. The banking situation: American post-war problems and developments. Columbia University Press,

Wood, Christopher. The bubble economy: the Japanese economic collapse. Sidgwick Jackson, 1992.1934.

Zhang, Ivy Xiying. "Economic consequences of the SarbanesOxley Act of 2002." Journal of Accounting and Economics 44, no. 1 (2007): 74-115.

White, Eugene Nelson. The regulation and reform of the American banking system, 19001929. Princeton University Press, 1983. 
The Budget and Staffing of Financial Regulation in the U.S.

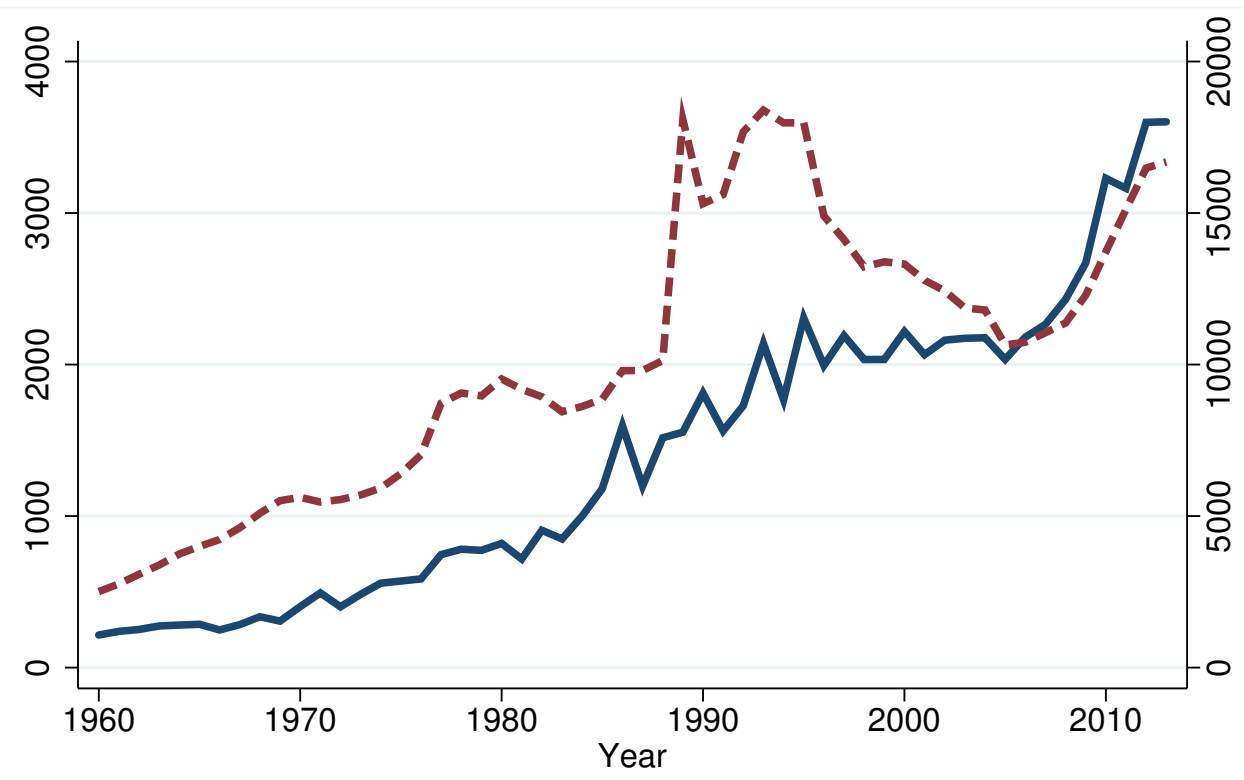

Budget (in real million dollars of 2005), left axis

Figure 1: The graph shows the staffing and the budget of financial regulation agencies in the U.S. from 1960 to 2013. The data are taken from a study from the Weidenbavm Center (Washington University) and the Regulatory Studies Center (George Washington University) derived from the Budget of the United States. 
The Budget of the Securities and Exchange Commission

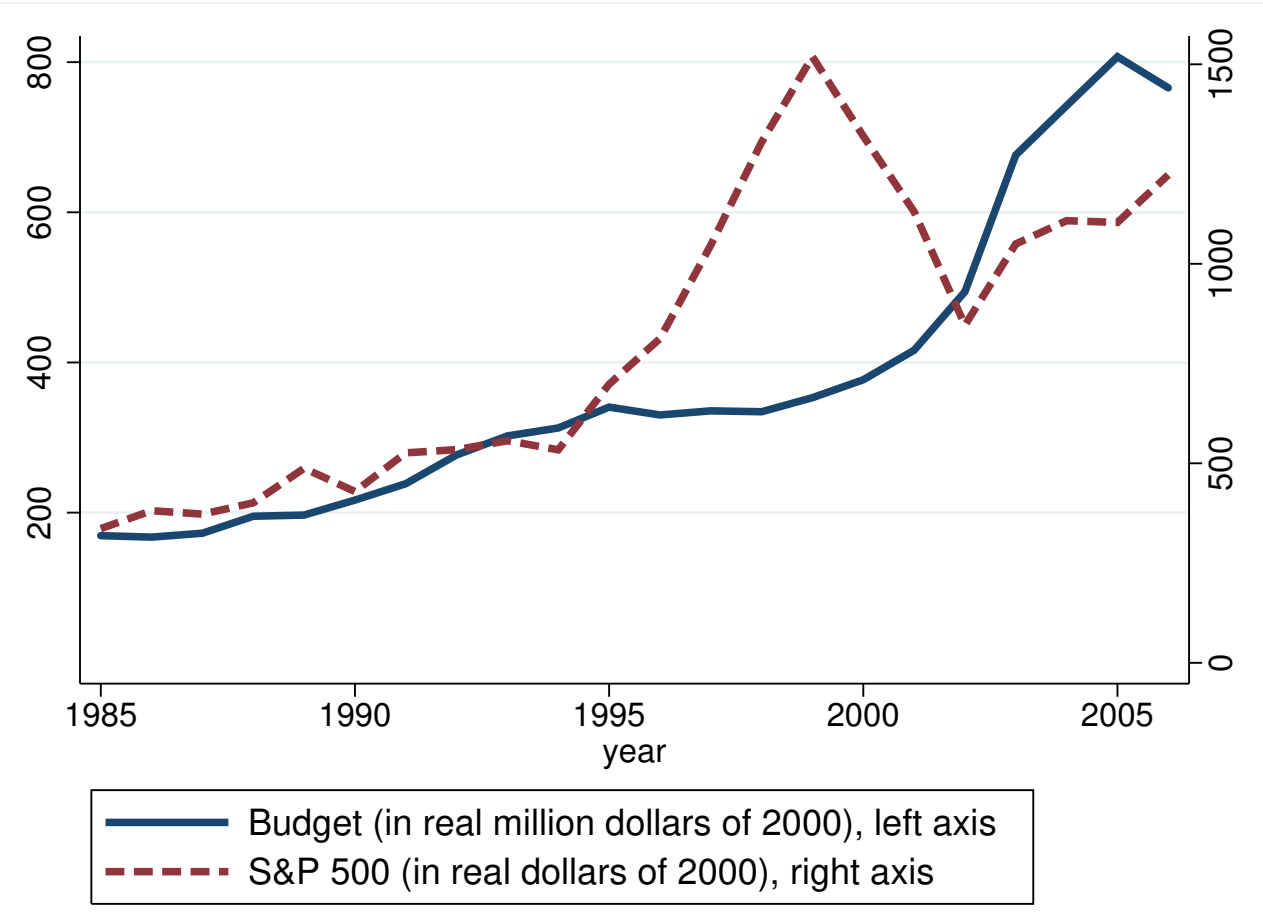

Figure 2: The graph plots the budget of the SEC, taken from the SEC (link), against the S\&P index. 


\section{The Budget of Financial Regulators: International Episodes}
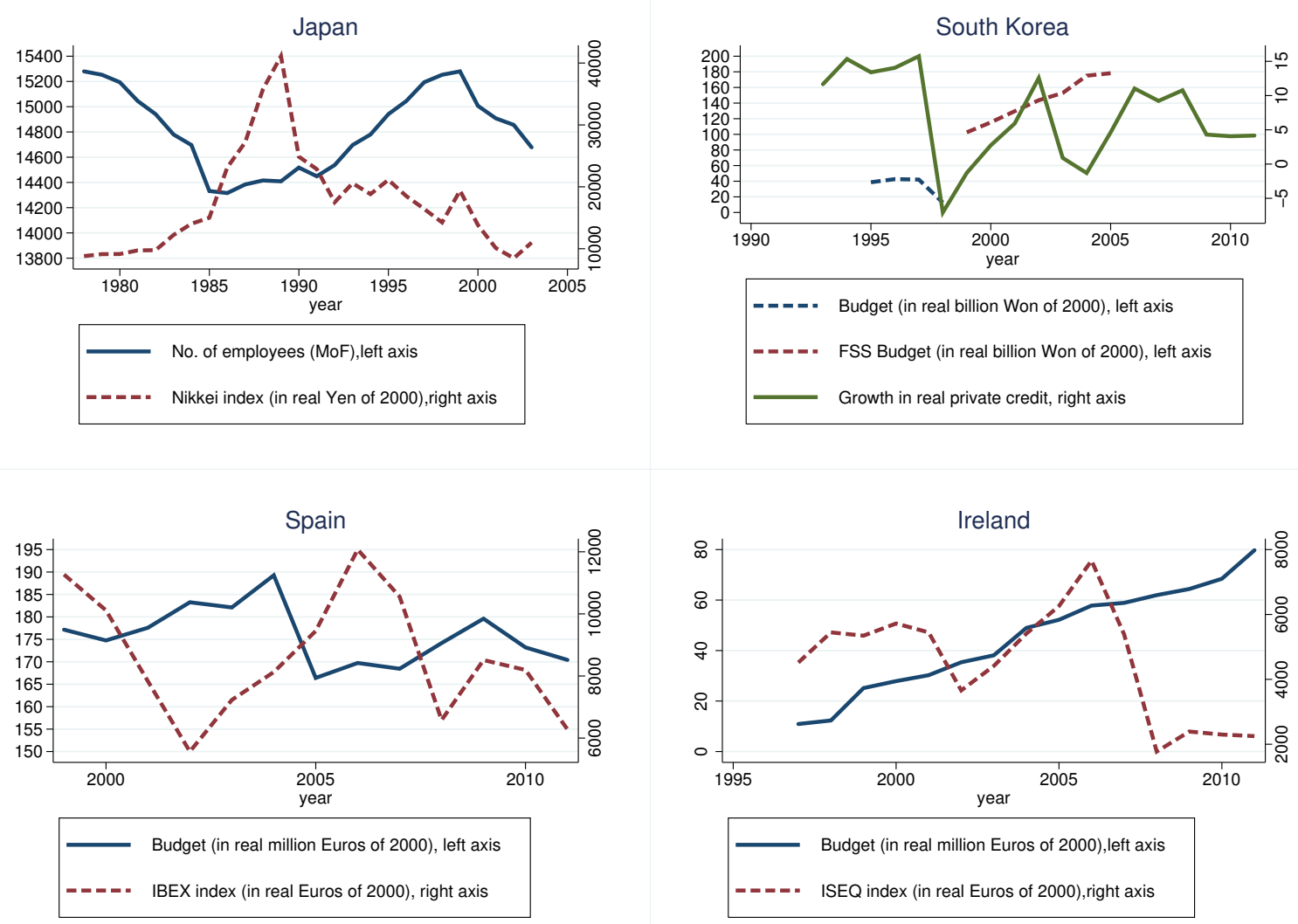

Figure 3: The panel includes four figures from four different countries and episodes. The Top left figure shows staffing at the Ministry of Finance in Japan during the boom-bust episode, plotted against the Nikkei index to provide the timing of the boom-bust. The staffing data are taken from the Bank of Japan link. The top right figure shows the budget of financial regulators in South Korea during the South-East Asian boom-bust episode. Since the authority of financial regulation has at least partly shifted from the Bank of Korea to a new agency (FSS) the pre- and post-crash figures are not comparable in levels (as discussed further in the text). The data are plotted against credit growth to show the timing of the crash. The sources of the budget data come from Bank of Korea link and Financial Supervisory Service link. The bottom left figure shows the budget of the Bank of Spain (BdE), plotted against the stock market IBEX index, from the most recent boom-bust episode. The budget data are taken from the Bank of Spain link. The bottom-right figure shows the budget of the Central Bank of Ireland which taken from the Central Bank of Ireland (link), plotted against the stock market ISEQ index. 


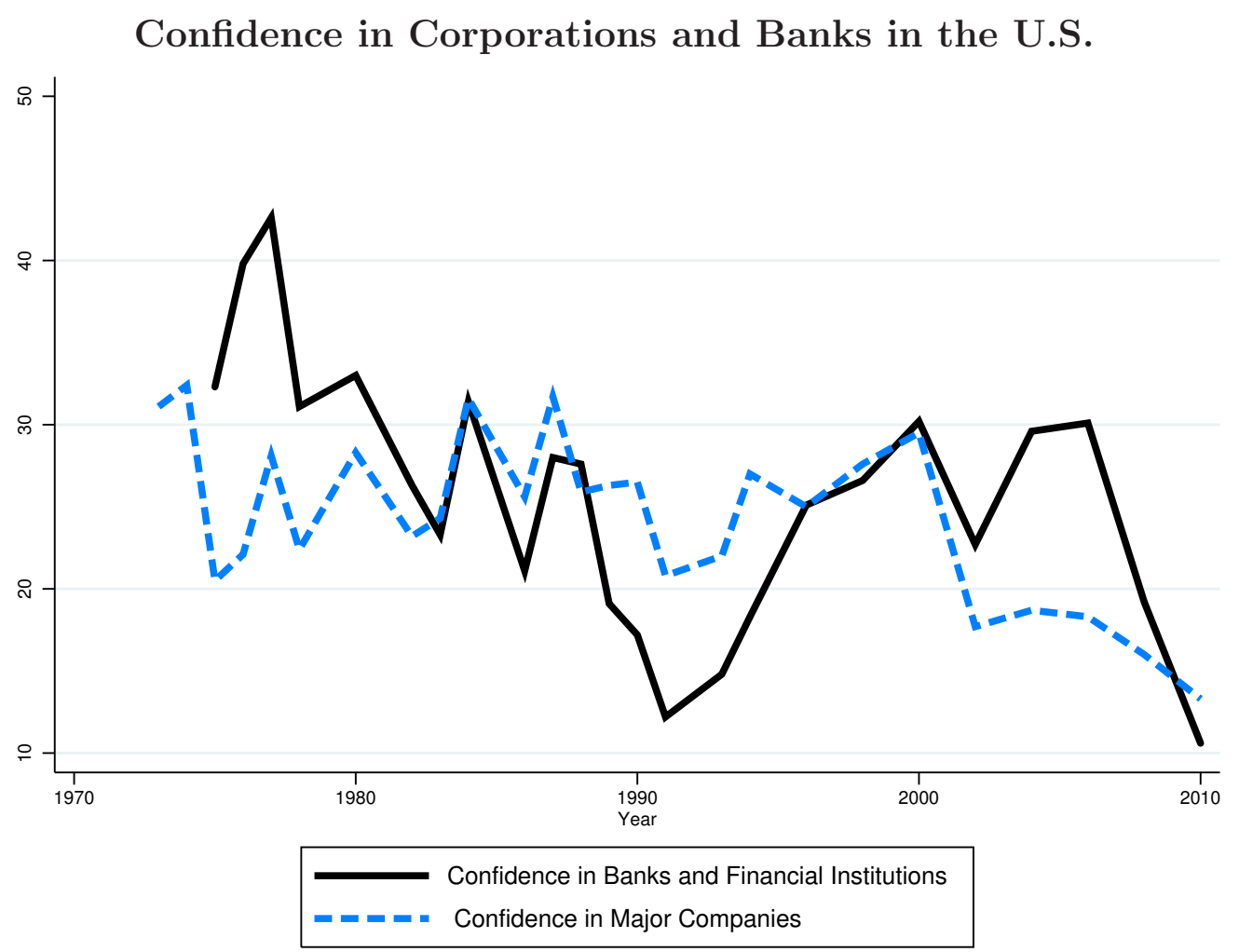

Figure 4: The graph shows the percent of the respondents who have a great deal of confidence in Banks and in Major companies. The data are the General Social Survey 2012 produced by the National Opinion Research Center at the University of Chicago. http://www.norc.org/ 
Table 1: Dependent variable: Regulation on bank capital

\begin{tabular}{lcccc}
\hline & $(1)$ & $(2)$ & $(3)$ & $(4)$ \\
VARIABLES & & & & \\
\hline & & & & \\
Post-crisis & 1.246 & $1.721^{* *}$ & 1.260 & $1.955^{* * *}$ \\
& {$[0.703]$} & {$[0.498]$} & {$[0.708]$} & {$[0.490]$} \\
Post-crisis*GDP per capita 2006 & -0.0140 & 0.0110 & $-0.0193^{*}$ & 0.00224 \\
& {$[0.00984]$} & {$[0.0220]$} & {$[0.00954]$} & {$[0.0228]$} \\
Post-crisis*Financial interconnectedness & -0.000678 & -0.00354 & -0.000877 & -0.00533 \\
& {$[0.00577]$} & {$[0.00512]$} & {$[0.00582]$} & {$[0.00559]$} \\
Post-crisis*Trade interconnectedness & 0.00765 & 0.00727 & 0.00787 & 0.00787 \\
& {$[0.00634]$} & {$[0.00498]$} & {$[0.00646]$} & {$[0.00487]$} \\
Post-crisis*English legal origin & -0.194 & -0.603 & -0.185 & -0.733 \\
& {$[0.469]$} & {$[0.421]$} & {$[0.463]$} & {$[0.470]$} \\
Post-crisis*Democracy & 0.223 & 0.297 & 0.212 & 0.291 \\
& {$[0.565]$} & {$[0.533]$} & {$[0.563]$} & {$[0.517]$} \\
Post-crisis*Crisis dummy & & $-2.103^{*}$ & & $-2.921^{*}$ \\
& & {$[1.036]$} & & {$[1.355]$} \\
Post-crisis*Fiscal costs (\%ofGDP) & & & $0.0287^{* * *}$ & $0.0982^{* * *}$ \\
& & & {$[0.00633]$} & {$[0.0172]$} \\
Country fixed effects & & & & Y \\
Observations & & Y & Y & 230 \\
R-squared & 230 & 230 & 230 & 230 \\
Number of newid & 0.262 & 0.308 & 0.265 & 0.336 \\
\hline
\end{tabular}

Note: The dependent variable is the degree of bank capital regulations taken from The Bank Regulation and Supervision Survey, carried out by the World Bank (see, for a reference, Barth, Caprio, Levine, 2012, Cihak, Demirguc-Kunt, Martinez Peria, and Amin Mohseni-Cheraghlou, 2012). Higher values indicate higher degree of capital regulation. The survey is taken in 2001, 2003, 2007, and 2011. A Post-crisis dummy is assigned for the survey taken in 2011. Financial and trade interconnectedness indexes are taken from IMF sources. The crisis dummy indicates whether the country experienced a banking crisis during the global financial crisis according to data from Laeven and Valencia (2012) which also provides the fiscal cost of the banking crisis. Data on The regressions control for country and time (survey) fixed effects. Robust standard errors are shown in brackets. ${ }^{* * *}$ indicates a 1 percent significance level, ${ }^{* *}$ indicates 5 percent, and * indicates 10 percent. 
Table 2: Dependent variable: Regulation on official supervision power

\begin{tabular}{lcccc}
\hline & $(1)$ & $(2)$ & $(3)$ & $(4)$ \\
VARIABLES & & & & \\
\hline & & & & \\
Post-crisis & 0.659 & 0.756 & 1.122 & 1.498 \\
& {$[1.217]$} & {$[1.282]$} & {$[0.967]$} & {$[0.887]$} \\
Post-crisis*GDP per capita 2006 & $0.0750^{* *}$ & $0.0817^{* *}$ & 0.0432 & $0.0591^{*}$ \\
& {$[0.0257]$} & {$[0.0276]$} & {$[0.0271]$} & {$[0.0297]$} \\
Post-crisis*Financial interconnectedness & 0.0138 & 0.0135 & 0.0141 & 0.0132 \\
& {$[0.0111]$} & {$[0.0113]$} & {$[0.0108]$} & {$[0.0110]$} \\
Post-crisis*Trade interconnectedness & -0.00711 & -0.00754 & -0.0115 & -0.0135 \\
& {$[0.0161]$} & {$[0.0165]$} & {$[0.0119]$} & {$[0.0115]$} \\
Post-crisis*English legal origin & 1.378 & 1.289 & 1.633 & 1.395 \\
& {$[1.326]$} & {$[1.397]$} & {$[1.369]$} & {$[1.405]$} \\
Post-crisis*Democracy & -0.397 & -0.378 & -0.573 & -0.539 \\
& {$[1.469]$} & {$[1.456]$} & {$[1.443]$} & {$[1.393]$} \\
Post-crisis*Crisis dummy & & -0.594 & & -1.848 \\
Post-crisis*Fiscal costs (\%ofGDP) & & {$[1.041]$} & & {$[1.004]$} \\
& & & $0.227^{* * *}$ & $0.264^{* * *}$ \\
Country fixed effects & & & {$[0.0228]$} & {$[0.0177]$} \\
Observations & Y & Y & Y & Y \\
R-squared & 312 & 312 & 312 & 312 \\
Number of newid & 0.104 & 0.104 & 0.124 & 0.129 \\
\hline
\end{tabular}

Note: The table shows results of panel regressions, where the dependent variable is official supervision power index taken from The Bank Regulation and Supervision Survey, carried out by the World Bank (see, for a reference, Barth, Caprio, Levine, 2012, Cihak, Demirguc-Kunt, Martinez Peria, and Amin Mohseni-Cheraghlou, 2012). The index measures the ability of the supervisory authority to promptly intervene, reconstruct, and declare insolvency of financial institutions. The survey is taken in 2001, 2003, 2007, and 2011. A Post-crisis dummy is assigned for the survey taken in 2011. Financial and trade interconnectedness indexes are taken from IMF sources. The crisis dummy indicates whether the country experienced a banking crisis during the global financial crisis according to data from Laeven and Valencia (2012) which also provides the fiscal cost of the banking crisis. The regressions control for country and time (survey) fixed effects. Robust standard errors are shown in brackets. $* * *$ indicates a 1 percent significance level, ** indicates 5 percent, and * indicates 10 percent. 